Historic, Archive Document

Do not assume content reflects current scientific knowledge, policies, or practices. 

GOLD MEDAL, ST. LOUIS EXPOSITION, 1904

Our Motto: Prices as Low as Consistent with Highest Quality
The Quality of an article is remembered long after the Price is forgotten
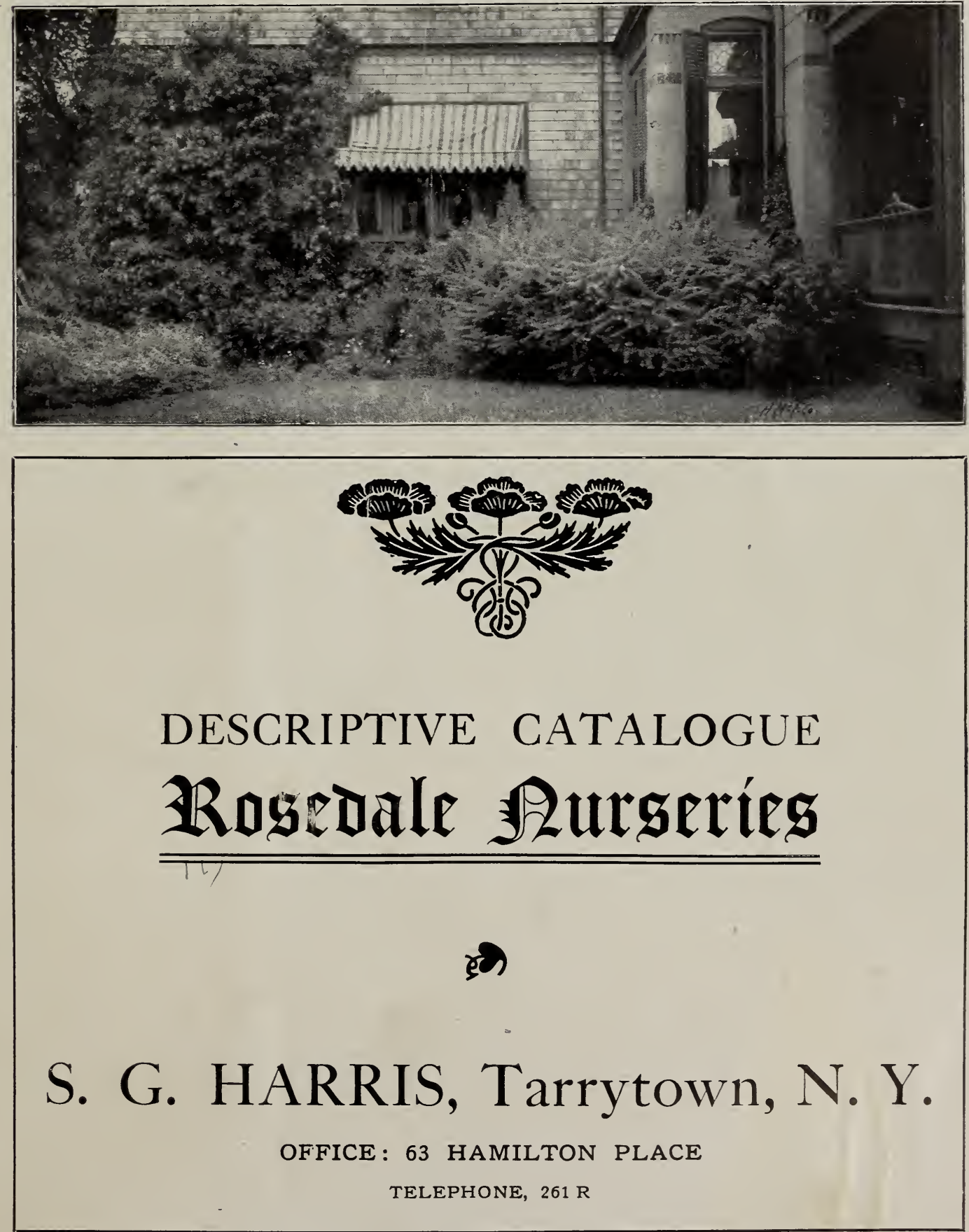


\section{Remarks to Customers}

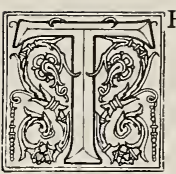

HANKING my customers for their generous patronage for the past year, I am pleased to anuounce that we are better prepared than ever to furnish strictly high-grade stock in all departments. We furnish annually many of the finest estates, parks and cemeteries in the country, which is proof that our goods are satisfactory both in quality and price. We solicit a trial order from those who have not previously had our plants.

Before Ordering, please send to us for quotations, if you do not find desired plants printed herein. Lowest rates will be given on trees by the hundred and thousand, and in car-load lots.

Early Orders.-Much time can be saved in the busy shipping season if customers will send in early orders. Spring orders should be in by March I5; and for fall by October I. Catalogue of bulbs will be sent in midsummer to all whose names appear on our list.

Fall Planting.-There are very few plants which cannot be planted as well in the fall as in the spring; most deciduous trees and shrubs do even better planted in fall.

No Substitutions are made without permission. It is well in ordering varieties of fruit and ornamental trees to name possible substitutes, especially in late orders, since some varieties are likely to be sold out.

Express.-Since Express Companies deliver plants, seeds and bulbs at a reduction of 20 per cent from the merchandise rate, we advise all shipments of small orders by that method. We guarantee safe arrival by express.

Plants by Express. We always add liberal extras to help defray charges. We make no charge for boxes or packing (except for heavy trees, at cost of materials). Prices are f. o. b. Tarrytown.

Remittances should be by express money order, post-office money order or bank draft.

No Accounts Opened for Less than \$10.-Less than this amount must be accompanied by remittance, unless a customer has a regular account.

Orders from a new customer must be accompanied by remittance or satisfactory reference.

Name and Address. - Please remember to write your name, post-office, county and state; also (when necessary) give number of street distinctly; also give the name of your express company.

Gardeners.-I keep a list of gardeners seeking employment, and shall be pleased to recommend to customers men of proper qualifications.

"It is my belief that the art of cultivating flowers must be regarded as no less important than the art of sculpture or painting, because the flowers form the most beautiful part of nature."

\section{HINTS FOR PROPER PLANTING}

To properly plant a tree or shrub is a very easy matter if one will carefully follow three or four rules.

FIRST.-Dig the holes large enough to admit the roots spread out in their natural position, and deep enough to allow the plant to stand at the same depth it stood in the nursery. More trees are lost by deep planting than by shallow.

SECOND.-Use no fertilizer, but sprinkle fine soil among the roots, shaking the tree a little if necessary, or using the hand, if the fibrous roots are very numerous, so that every root may come in contact with the soil.

THIRD. - When the roots are well covered, the earth should be tramped, or tamped, as firm as a post. Put in more earth and tamp again. The last two or three inches of earth should not be tamped, leaving it loose for the rain to be taken in. Do not round up the earth about the tree, lest the water run off. If the weather is dry early in fall or late in the spring, water may be poured in about the tree; otherwise, it is seldom necessary.

Fourth.-Give the tree a good mulching to hold the moisture.

\section{TREES AND SHRUBS FOR NURSERY PLANTING}

Where large future plantings are to be made in cemeteries, parks or large estates, the economy of growing trees for a year or more in the nursery row, from which they are readily transplanted to other parts of the grounds, is evident. The cost of packing, transportation, etc., is hereby reduced to the minimum, and the cost of the plants is inconsiderable.

Having best facilities for furnishing nursery-grown, twice-transplanted stock, we solicit opportunity to quote prices to those intending large plantings.

Deciduous trees of all the leading varieties, in sizes from 2 to 3 feet up, and evergreens from I to $2 \frac{1}{2}$ feet.

PREMIUM OFFER. In order that all our customers who do not keep an experienced gardener may have reliable instruction in care of plants, we will send free with every cash order of \$10, BAILEY'S “AMATEUR'S PRACTICAL GARDEN-BOOK," or BAILEY'S “GARDEN-MAKING."

\section{INDEX}

The lists in our Catalogue being arranged alphabetically in each group, the short index below will, we believe, be found more convenient than a very extended one

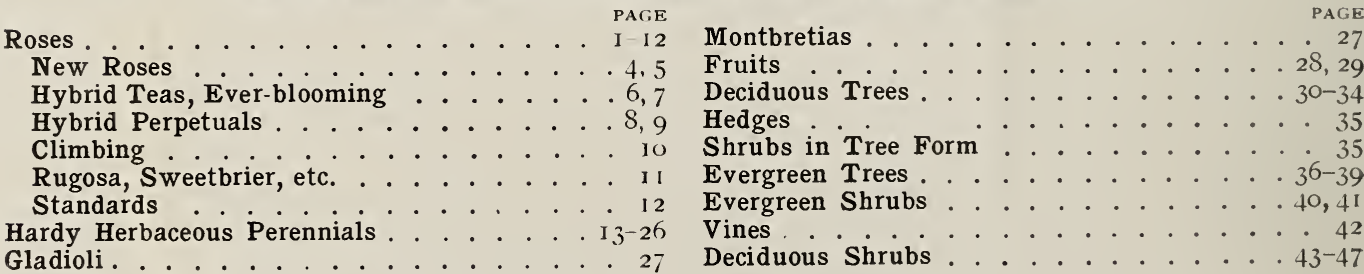




\section{ROSES}

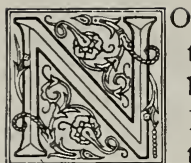

garden is complete without Roses, yet how few good collections are found. The fact is that there are many varieties entirely unworthy a place. To want of knowledge of the best varieties is largely due the lack of abundant blcom. More has been written on the Rose than on any other fluwer, but little has been read, evidently, by many who attempt to grow Roses. For the average Rose garden comparatively few varieties are suitable from the eleven classes. Having made a study of the Rose for many years and tested different varieties on different soils, we feel competent to offer advice as to proper location, selection of varieties, and culture of the "queen of flowers."

We have endeavored to present the merits of each variety fairly, saying rather too little than too much. The fact that our sales increase enormously from year to year is proof that our selection and prices are right. Many of our customers are so enthusiastic that their friends become ours. The following list has most of the really good Roses, and no poor ones. They are all strong, two-year-old plants, carefully selected, and grown on land especially adapted for Roses

The cut herewith shows two-year-old field-grown plants showing grand root system. The line above root shows the depth plants should be set -2 to 3 inches above the bud. Upper line shows where tops should be pruned, although weak growers should be pruned more and strong growers less. Climbing Roses should be pruned very little.

As a preventive of insect attacks, dust hellebore (r part) and flour ( 2 parts) on the foliage when leaves are fully expanded. This done in the morning, dew and flour forms a paste to hold poison on the leaves. One application at the right time is usually sufficient to keep the foliage as clean as desired.

We take pleasure in offering a select list of Roses, heavy plants, which will easily pay for themselves in bloom the first year. Why not have the best, since a good plant requires no more space or care than a poor one, except to pick the extra blooms? A Rose garden cannot be made of weeds. Of thousands of varieties, not more than one hundred are worth grow-

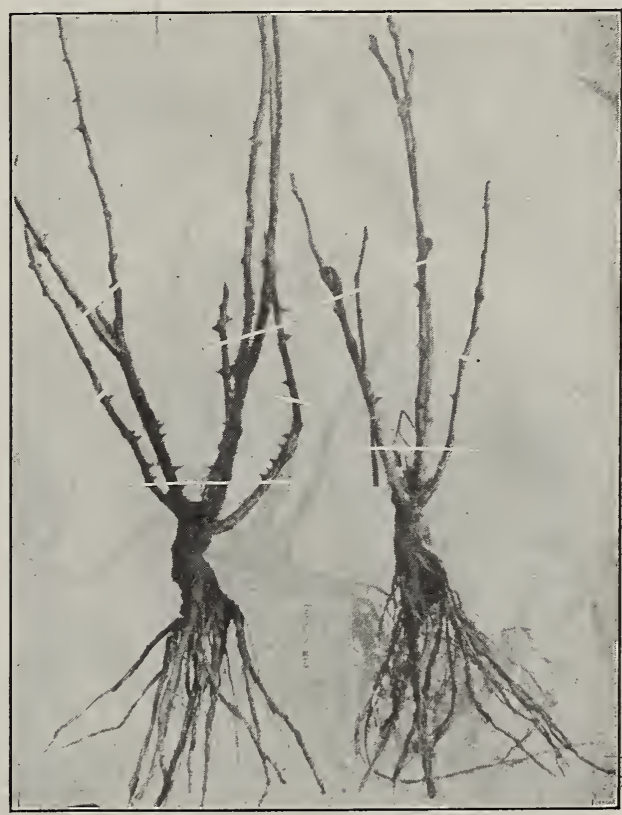

Note the magnificent root system in this cut from photograph of Hybrid Teas ing in any given locality, unless one has a very large Rose garden. Some varieties do well in one section, some in another.

When we say we $1:-$ ve only first-class varieties and first-class plants of all colors of Roses, including several of the best yellow sorts, we are prepared to back up our statements; and, as the Rose has long been acknowledged the "queen of flowers," and has held its place as such among nearly all flower lovers, we have spared no pains to provide our customers with heavy two-year-old plants, which will produce grand blooms the first season. We offer several thousand plants, grown by Dickson \& Sons, of Ireland, including Killarney, Mildred Grant, Bessie Brown, etc. No Holland stock.

By permission lwe submit two samples of many letters received from our customers:

Washington, Dec. I4, I904.

The Roses came in good shape and are doing nicely. I will speak of you to our rosarians. Your Roses have the finest roots I have ever seen. I now have a number of Roses in bloom out-of-doors, a little late, even for Washington. REV.S. S. Sulliger.

Cincinnati, Ohio, Sept. io, roo4.

As an experiment last year, I sent similar orders to a number of leading dealers and growers, and it is but fair to you to acknowledge the superiority of your goods.

W. A. HALL.
That we have succeeded in pleasing the public may be seen from the increased demand and the many letters or commendation from our customers. Our stock this year is as fine as silk, all of the choice newer varieties and the cream. of the older, as described in this Catalogue.

\section{BUDDED vs. OWN ROOT PLANTS}

Growers are apt to argue for their own method of propagation. An impartial opinion by an eminent rosarian may be found in an excellent article by Dr. Robert Huey, in the March, I905, number of "Country Life in America." Speaking of budded plants, he says: "They are much more vigorous, produce finer blooms, come into bearing sooner and last just as long, if not longer." He further states that "many fine varieties are utterly worthless unless budded." 


\title{
NEW ROSES
}

All our Roses are field-grown, heavy two-year-old plants, no potplants; no Holland stock; no second size

\section{NEW ROSE, BABY RAMBLER}

Among the six most popular new Roses is the new bedding Rose, Baby Rambler, which blooms freely from June to November. It is a cross between Crimson Rambler and one of the dwarf Polyantha sorts. It grows in compact bushes, 18 inches high, with clean, dark green foliage. It has received the following medals and certificates: Grand Silver Medal at Paris, May, I 904 ; First-class Certificate National Horticultural Society of France, November, 1904; First-class Certificate Royal Horticultural Society of London, April, Igo4; First-class Certificate National Rose Society of Eng., June, I904; Gold Medal at Orleans, France, I904.

\section{NEW HYBRID TEA ROSES}

\author{
(Except as Noted)
}

The following choice list has been thoroughly tested by our customers, to whom we ship in nearly every northern state and in

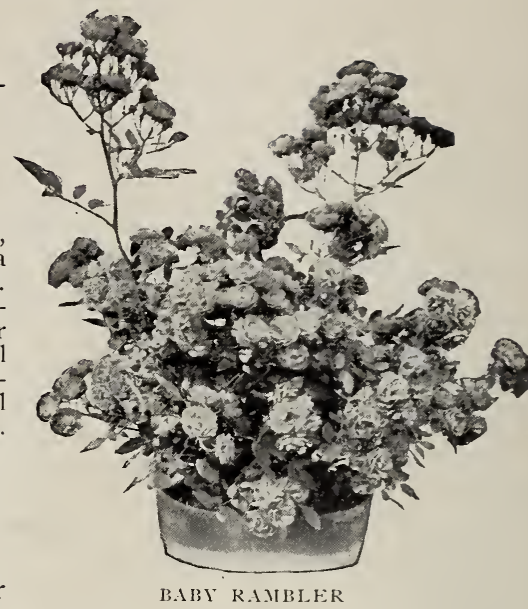
Canada. Of course, the Hybrid Teas need some protection in the North. The best method is to lay down the plants and cover with a small quantity of earth just before winter sets in, which is about Thanksgiving Day in the vicinity of New York. Then after the ground is frozen, cover the bed with a good coat of leaves, which should be taken off early in spring. Many growers in this latitude cover only with leaves, on top of which evergreen boughs or other weight is placed to hold the leaves from blowing away.

25I3 ALICE GRAHAME. Ivory-white, tinted salmon. In this variety we have an absolutely distinct and magnificent Rose of the highest excellence. It is a strong vigorous grower, of free and erect branching character, with massive dark-green foliage. Growth very smooth, with the appearance of being highly varnished. Every shoot is crowned with a bud, which develops into a flower of large size, enormous substance and perfect form. This variety frequently varies both in form and color. A marvelously free and continuous blooming Rose.

2426 ARDS PILLAR. Rich velvety crimson, the perfection of an exhibition, garden and pillar Rose; the growth is very vigorous, with very large, most distinct and attractive foliage; the blooms are produced with great freedom, and are large, full and of cupped form; petals very large and smooth; one of the finest varieties

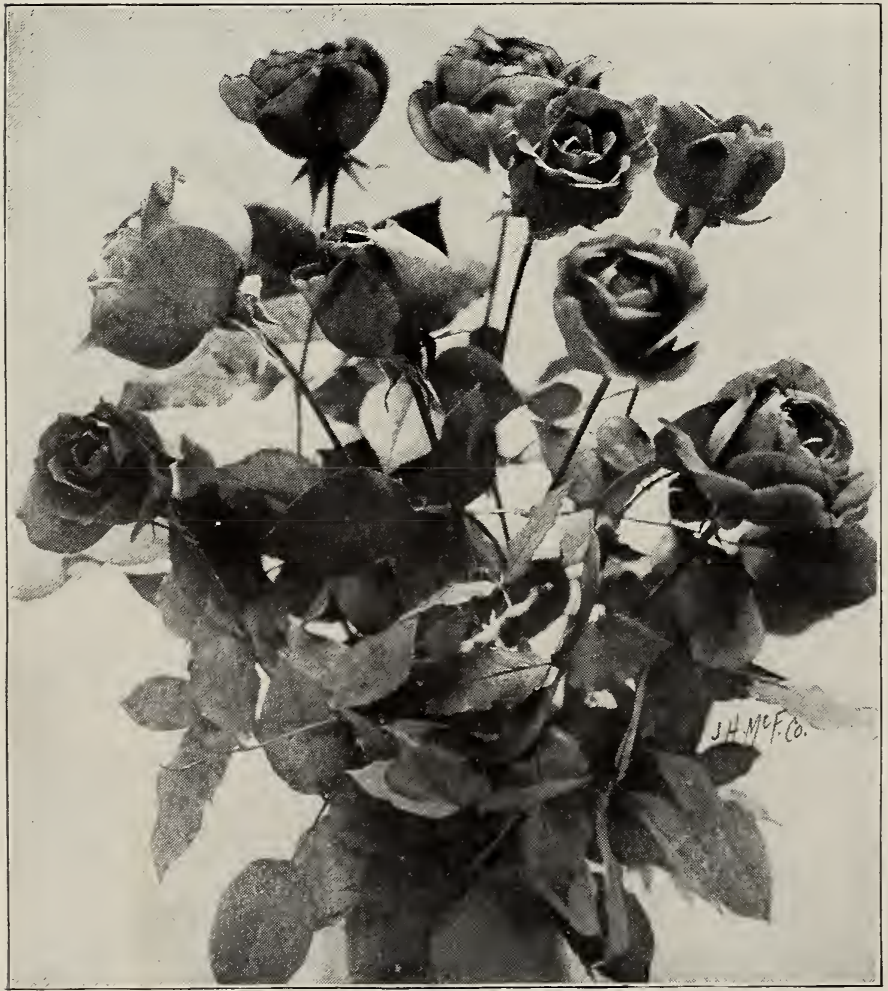

GRUSS AN TEPLIT\% sent out of late years.

2486 BETTY. Color ruddy gold (a coppery Rose overspread with golden yellow). Its blooms are extremely large, fairly full and of a glorious form; petals often 4 inches long, and is never out of bloom from June until cut off by frost. Its growth is extremely vigorous, erect and of very free branching habit.

2056 BERYL. Tea. Deep golden yellow; buds long and perfectly shaped; very highly perfumed. Wherever cut-flowers are in demand for buttonholes or decorative work this will prove a most valuable acquisition.

2656 CHERRY - RIPE. L i g h t cherry-crimson, very fragrant; flowers medium-sized, well formed, full and globular; a very floriferous bedding Rose, also first-rate for forcing.

is8o CLARA WATSON. Salmon, tinted pink.

2660 COUNTESS OF DERBY. Form identical with that of Catherine Mermet, while its growth is infinitely superior and the quantity of bloom produced in excess of that grand variety. Blooms large, perfectly symmetrical, with highly pointed center; petals large, smooth and shell-sliape; color, center salmon, outer petals rose, passing to flesh-veined peach as the flower expands. Very vigorous and erect growth, very free branching habit, very free-flowering throughout the season. Good for exhibition, garden decoration and forcing purposes. Deliciously perfumed. 


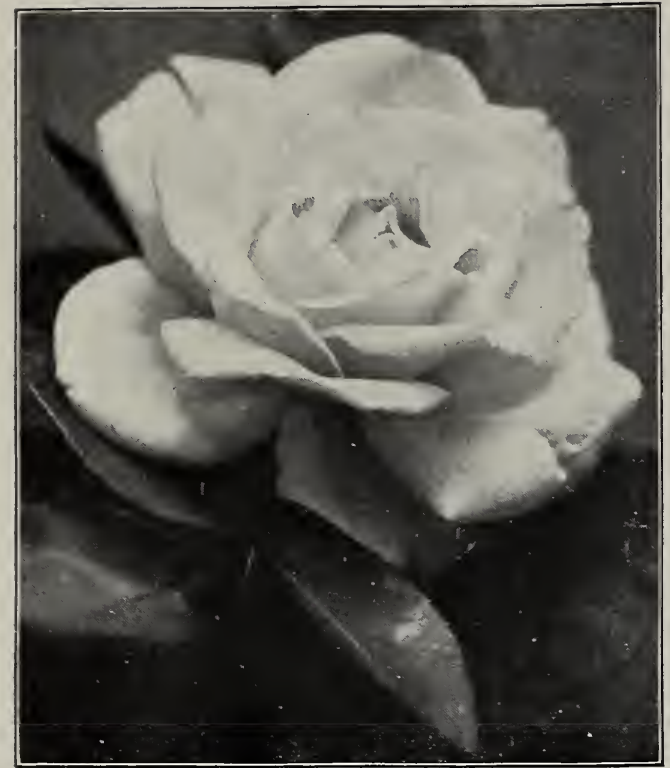

FRAU KARL DRLSCHKI

NEW HYBRID TEA ROSES, continued

2589 DEAN HOLE. Silvery carmine, shaded salmon; absolutely distinct and by far the finest in its way of color. The growth is vigorous, branching and very floriferous; flowers large, of great substance and fine form. A variety of great excellence and useful for any purpose. Gold Medal National Rose Society.

259i DR. J. CAMPBELL HALL. Coral rose, suffused white, base of petals yellow; a charming Rose of a color too difficult to describe. The flowers are large, full and perfectly formed; very floriferous; a really grand Rose for any purpose.

2596 ETOILE DE FRANCE. Color velvety crimson, center vivid cerise-red; blooms very large, full and magnificent; cupped form; very beautiful. Vigorous in growth; fragrant and lasting.

126I FRAU KARL DRUSCHKI. H. P. We cannot speak too highly of this grand Rose. It is perfectly hardy, vigorous and a free and continuous bloomer. No rose has attracted greater attention of late years than has this one. It is the purity of whiteness. IVe sold more plants of this Rose last season than of any other variety, Mildred Grant holding it a close second To meet the great demand next season, we have secured a large stock of seiect plants. Blooms very large, perfectly formed; snow-white, with shell-shaped petals, opening well; strong and vigorous; an ideal white Rose. Has won many prizes since its introduction in I900. See standards, page I 2 .

"This is by far the finest Rose.

"It is the finest and most free hybrid perpetual. "A good autumnal Rose.

"Lovely flowers can be cut from this Rose in the autumn. It is the most constant bloomer never ceasing to flow'er ti!l slopped by frost.'

243i FRAU PETER LAMBERT. Deep rose, shaded salmon; flowers very large, full and of perfect form; bud long and carried on erect stem; growth rigorous and branching. Closely resembles Kaiserin Augusta Yictoria, of which it is a sport ; marvelously freeflowering and fragrant. A good Rose for any purpose.

78 I GRUSS AN TEPLITZ. carlet, shaded with velvety fiery red; red a very effective decorative Rose. It is very fragrant, a free, strong grower and the most profuse bloomer of all bedding Roses. The foliage is extremely beautiful, all the young growth being a bronzy plum-color.
2 I03 KILLARNEY. A charming Rose of robust growth and free branching habit; blooms large, buds long and pointed; petals very large and of great substance; flesh shaded white, suffused pale pink ; a lovely and distinct Rose of great merit.

2300 LADY GAY. Polvantha. Seeding from Crimson Rambler; flowers of good size, delicate cherry-pink, fading to soft white; borne in very large clusters; a magnificent variety.

2344 LADY BATTERSEA. Beautiful cherry-crimson, permeated with an orange shade; the flowers are of moderate size and almost full; very free-flowering.

$26 r 4$ MRS. CONWAY JONES. Creamy white, flushed salmon-pink; flowers large, full and good form; petals of great size and substance. First-rate variety.

2366 MILDRED GRANT. Silvery white, edge of petals shaded and bordered with pink; blooms are of enormous size and great substance, with high-pointed center, and last long in good condition. The petals, which are of unusual length, are perfectly shell-shaped and very massive; the growth is robust, vigorous and absolutely distinct, every shoot being crowned by a flower-bud, which is carried on a perfect!y erect and very stout flower-stem; the wood and foliage, which is light glossy green, is most striking and attractive. Altogether this is the grandest variety erer raised, and may be termed the Rose of the Century. Received a Gold Medal from the National Rose Society of England. See illustration.

26 I MRS. DAVID McKEE. Creamy yellow: flowers large and of splendid size; very floriferous; a first-rate variety for exhibition, garden decoration or pot culture. Gold Medal.

2452 MRS. THEO. ROOSEVELT. Creamy white, center rose : bud long and pointed, flowers very large, full and well-formed.

2627 HUGH DICKSON. H. P. Brilliant crimson, shaded scarlet; good size and fine form ; petals smooth, slightly cupped and reflexed. Free-flowering and vigorous in growth; very highly perfumed. Gold Medal.

2I 7 I MRS. MAWLEY. Tea. Superb variety : a chaste and perfectly formed flower of marvelous beauty: The growth is vigorous and of branching habit, flowering with the greatest freedom throughout the entire season: the blooms are very large, of great substance, beautifully formed, with highly pointed center, from which the petals reflex; bright carmine, shaded with salmon; very sweet-scented. Awarded Gold Medal, National Rose Society.

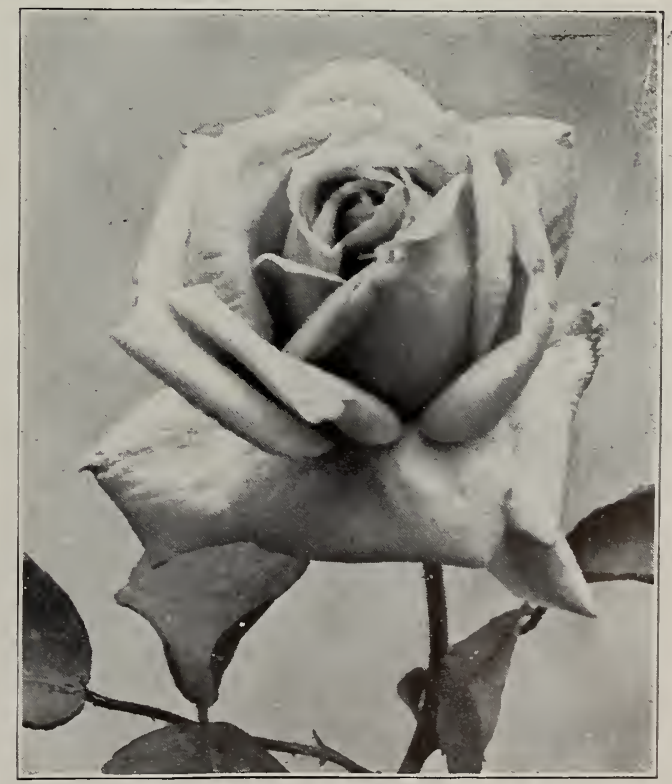

MIILDRED GRANT 


\section{NEW AND HYBRID TEA ROSES, continued}

2687 PEGGY. A charming Rose of very robust and perfect habit. The feature of this Rose is its exquisitely shaped semi-double, claret-smeared, saffron-yellow blooms passing to a pale primrose as it expands, which are borne in large trusses in the greatest profusion. Without question one of our very best productions for all decorative purposes.

2697 REV. DAVID R. WILLIAMSON. Dark velvety crimson, shaded maroon; flowers of large size, good substance and globular form; a very useful Rose.

2689 RICHMOND. Color pure red-scarlet. Of freegrowing and flowering habit; much in advance of Liberty, especially for forcing purposes.

2213 SOLIEL D'OR. Hybrid Perpetual. The only yellow Hybrid Perpetual. A cross between Persian yellow and Antoine Ducher; it has the perfect hardiness of the former, with more full, globular flowers, varying in color from gold and orange to reddish gold, shaded with nasturtium-red. Strong two-year plants.
242I SOUVENIR DE PIERRE NOTTING. Tea. Apricot yellow, blended with coppery yellow; bud long, opening into a large, full and finely formed flower; a very distinct and beautiful variety.

2150 WEDDING BELLS. Polyantha. A superb new Rambler of vigorous growth, and the most floriferous variety in cultivation; flowers are produced in immense clusters and semi-double; color lovely shellpink; base of petals white.

856 ZEPHERINE DROUHIN. Bourbon. This is an old Rose which is very popular with those who have been fortunate in securing it. It is large, semi-double and of exquisite rose-color; a very strong grower, and may be used either as a pillar or bush Rose. Very sweet and floriferous.

2555 TRIER. Semi-double, producing large clusters of creamy white flowers in great abundance all summer. One of the best new climbing Roses.

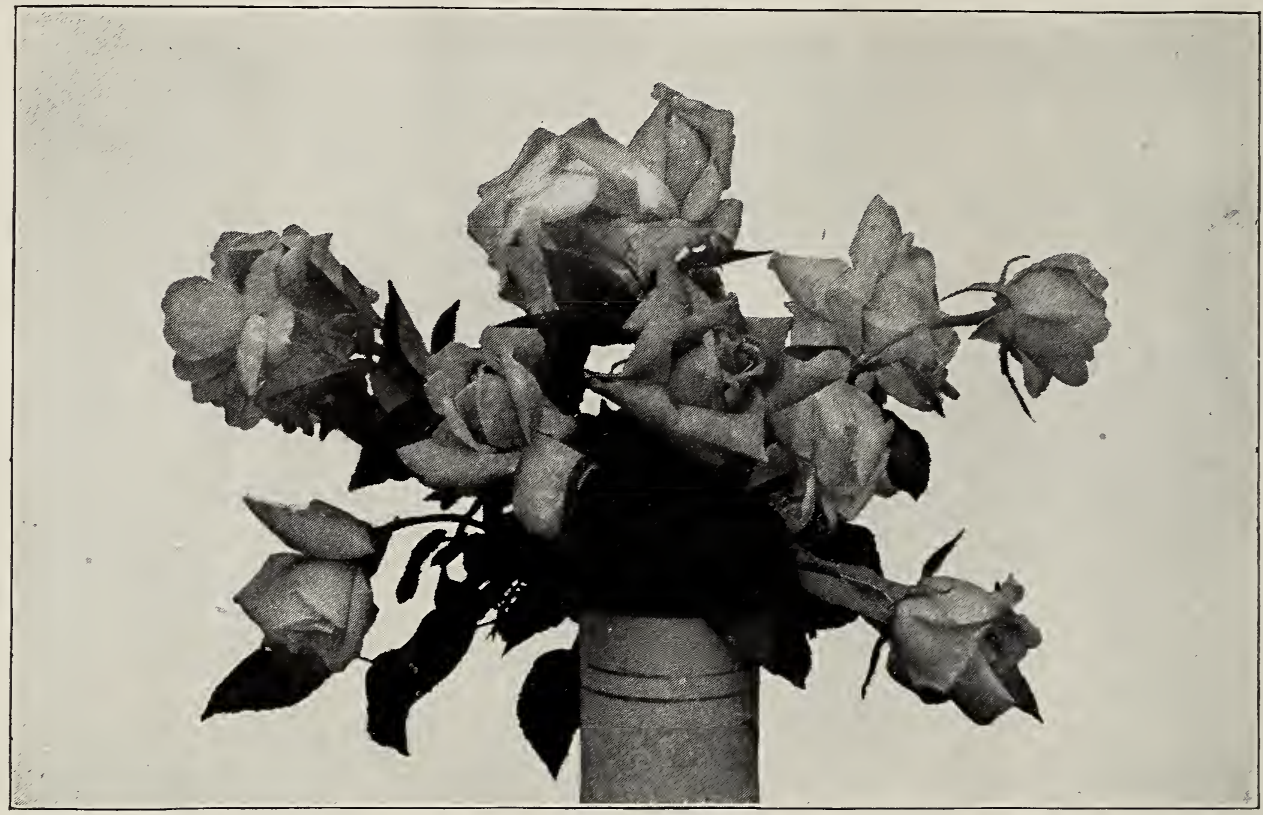

TEA ROSES

\section{SELECT LIST OF EVER-BLOOMING ROSES}

In addition to the list of New Roses we offer the following varieties, the very cream of constant bloomers. They should not be confounded with the so-called monthly Teas sent out as pot-plants by some firms. They are hardy with a little protection if planted in spring, in order that they may become established during summer. Being large plants they will bloom freely from June to November, and are worth many times mailıng sizes, sent out by some growers. As they have all been thoroughly tested for hardiness, freedom of bloom and vigorous growth, one tries no experiment in planting these beautiful Ever-blooming Roses. They are all Hybrid Teas with the exception of a few, which are designated, and, all things considered, are most valuable for bedding out and summer flowering. They are a cross between the Hybrid Perpetuals and the delicate Teas. They have the hardiness of the former and the charming form and fragrance of the latter. This is the class to which La France belongs.

755 Antoine Rivoire. Rosy flesh, shaded and edged with carmine; base of petals yellow, large, full and imbricated; superb.

2094 Balduin (Helen Gould). Beautiful pure carmine; large, full and fragrant; a most continuous flowering Rose.

759 Belle Siebrecht. Bright rosy pink; large, double and beautifully formed; very sweet and exceedingly floriforous. One of the best.
265 Bardou Job. Tea. Flowers large, saucershaped, rich crimson, shaded with black, semi-double and very beautiful; foliage large and leathery. Plant exceedingly vigorous and productive.

${ }_{21} 8_{3}$ Bessie Brown. A rose of transcendent beauty. totally distinct. The blooms are perfectly formed, of immense size and substance; petals very smooth and shell-shaped; creamy white; very highly perfumed. One of the finest Roses ever raised. 


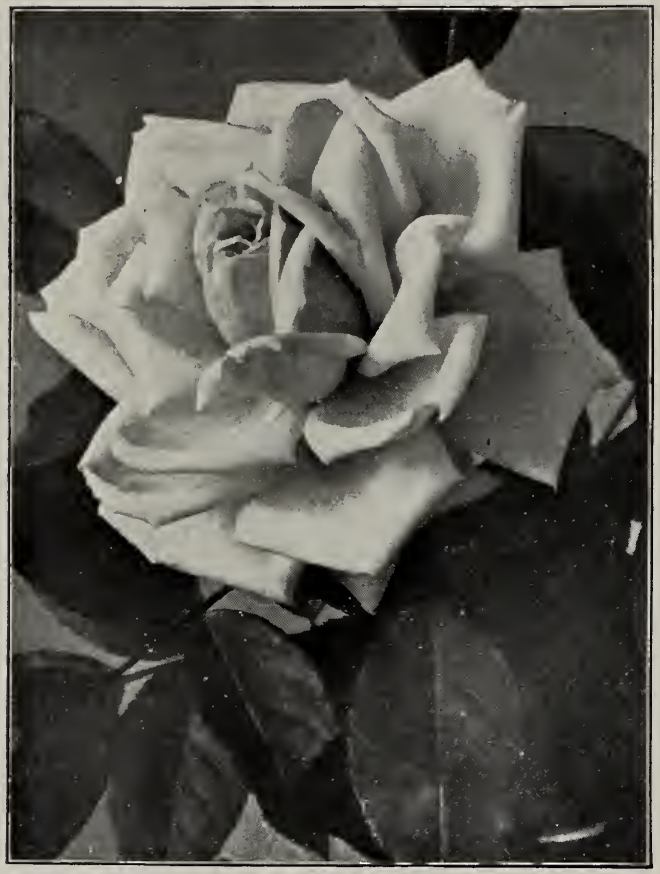

CAPTAIN CHRISTY

630 Captain Christy. Delicate flesh-color, deeper in the center; large. Effective; one of the best.

803 Caroline Testout. A beautiful rosy salmon; exquisite form, very sweet ; vigorous grower, free and constant bloomer.

800 Clothilde Soupert. Polyantha. Fiowers medium size, very double and beautiful, varying from light to pink. No better light Rose for bedding, whether we consider its profusion of bloom the entire season or its vigorous growth.

2233 Corallina. Tea. Flowers deep rosy crimson; very pretty in the bud state and highly perfumed; a splendid autumnal bloomer.

I259 Duchess of Al bany. Fine deep pink an improved La France. Several first-class certificates

36r Enchantress. Tea. Flowers creamy white, slightly tinted with buff in the center great freedom of bloom, especially in autumn.

777 Ferdinand $\mathbf{B a}$. tel. Varies from a pale rosy flesh on a ground of yellow-nankeen to yellow nankeen-orange large and full.

2257 Franz Deegan. Flowers large, full and fragrant; rich yellow, shading to orange in the center. Like its parent, Kaiserin Augusta Victoria, a vigorous grower and continuous bloomer.
225 Gladys Harkness. Deep, salmon-pink, of good shape; large and fragrant ; vigorous, floriferous.

39I Grace Darling. Creamy white, tinted and shaded with peach; distinct flowers, large and full. One of the best.

743 Gustave Regis. Canary-yellow, with orange center; beautiful in bud.

4or Gustave Nabonnand. Tea. Delicate rose, shaded with yellow; fragrant and free-flowering; extra.

789. Kaiserin Augusta Victoria. Pure white, with yellow center; outer petals reflexed; its fragrance is unique, its foliage vigorous and glossy.

2260 Lady Clanmorris. Creamy white with delicate salmon center, edge of petals margined pink sweetly perfumed; vigorous and free-flowering. A fine variety.

794 La France. Beautiful pale peach, rose center; very large and full; free bloomer. An old favorite, without which no collection is complete.

2262 Liberty. Flowers of large size, rich velvety crimson, and of exquisite fragrance.

797 Madame Abel Chatenay. Rosy carmine, shaded with pale vermilion-rose, and tinged with salmon; very distinct and attractive.

8or Madame Cadeau-Ramey. Rosy flesh, shaded with yellow at base of petals; large, full, and of perfect form. One of the best newer Roses.

8ro Madame Jos Combet. Creamy white; large, full, fine form. A grand Rose ; rather late blooming.

8I4 Madame Jules Grolez. Fine, satiny chinarose color; very bright and attractive : large, full and of good form and very free-blooming. A distinct and excellent new Rose. Regarded as one of the best new Roses in Europe.

2196 Madame Ravary. Hardy and very floriferous; color beautiful orange-yellow; flowers very large. The best yellow Rose.

589 Maman Cochet. Tea. Flowers large, full and double; color clear carmine-rose; exquisite in bud Blooms in great profusion; very fragrant. Almost as hardy as the Hybrid Teas.

While our descriptions do not laud these varieties to the skies, as some do. yet our extra selected 2-year plants are rarely equaled. See photo-engraving, page 3 , of two plants, roots of which were too large for an 8-inch pot 


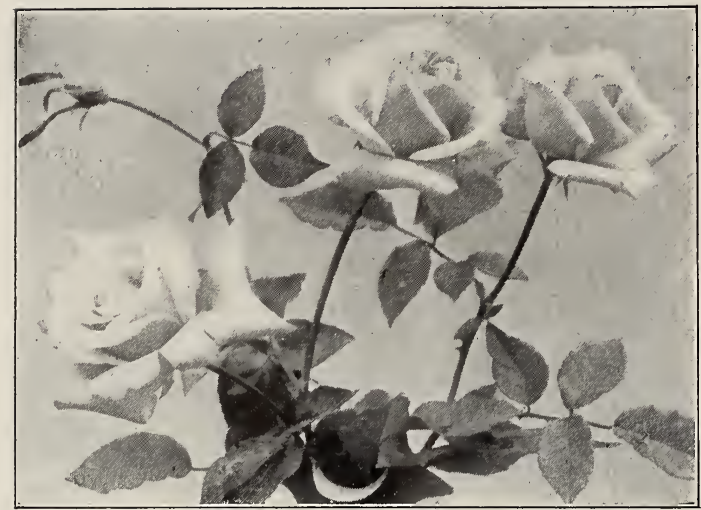

MAMAN COCHET

EVERBLOOMING ROSES, continued

2 Io8 Mrs. Robert Garrett. Enormous in size; buds long and pointed, open flowers full and double; color delicate pink; very free-flowering and fragrant.

227 Perle d'Or. Polyantha. Flowers small, full ; nankeen-yellow, with orange center. One of the best for edging beds.
229 Pink Soupert. Polyantha. In the way of Clothilde Soupert, except color, which is a bright clear pink; very free-flowering and fragrant.

8r8 Madame Pernet Ducher. Large, full; canaryyellow. Very free-flowering.

848 Souv. du President Carnot. Rosy flesh, shaded with white; fine long buds on stiff and long stems; delightfully fragrant. One of the best everblooming Roses ever introduced.

992 Souv. de la Malmaison. Bourbon. This is the best of all Bourbon Roses. One of the best fleshwhite Roses in cultivation; especial favorite because of its large sweet roses, continuing in bloom until late in the season.

849 The Meteor. Dark velvety crimson; very free and valuable for cutting

742 Viscountess Folkestone. Creamy pink, center salmon-pink; large and sweet. Extra variety.

853 White Lady. Magnificent creamy white flowers with magnolia-like petals. One of the handsomest and most effective Roses; weak grower.

590 White Maman Cochet. Tea. Habit strong and upright like its parent, Maman Cochet, having all the fine qualities of that grand Rose. Flowers are of enormous size, remarkably round and full; clear snowy white throughout and very fragrant.

724 Wuotton. Flowers large, full; beautiful red; sweet and free-blooming. A grand Rose.

\section{HARDY HYBRID PERPETUAL ROSES}

'The following list, selected for hardiness, freedom of bloom, vigorous growth, fragrance and form, includes only first-class sorts - the cream of remontants. The plants are select, extra-size, two-year-old; grown on land especially adapted for Roses. In planting, the bud or joint should be planted 2 or 3 inches below the surface, which to a great extent prevents wild shoots. If one does appear it is readily recognized by its seven leaflets and is easily removed. About fifteen varieties may be had on own roots if desired. Formerly we offered Holland-grown stock at $\$$ I 5 per IOO, but about 99 in roo of our customers prefer to pay a little more for the best. We therefore offer no Holland stock.

American Beauty. Flowers very double, of deep pink color and very fragrant. A superb forcing variety, but seldom succeeds out-of-doors in the East.

Alfred Colomb. Bright carmine-red; large and full, fine globular form.

Anne de Diesbach. A beautiful carmine of perfect form and very sweet.

Baron de Bonstetten. Rich, velvety maroon; large and full; very fine.

Baroness Rothschild. Light pink,suffused with white; large, globular form; extra fine.

Ben Cant. Flowers large and finely formed; deep clear crimson, darker in the center; sweet-scented, thoroughly perpetual; very promising.

"It is undoubtedly one of the finest Hybrid Perpetuals of its color ever raised." - The Garden, London.

Bob Davison. F lowers large, very full, of perfect form; dazzling scarlet, shaded crim son.

Captain Hay ward. Bright crimson; quite a new shade; very sweet.

Clio. Flesh-color, shaded in the center with rosy pink; flowers large and globular; handsome foliage.

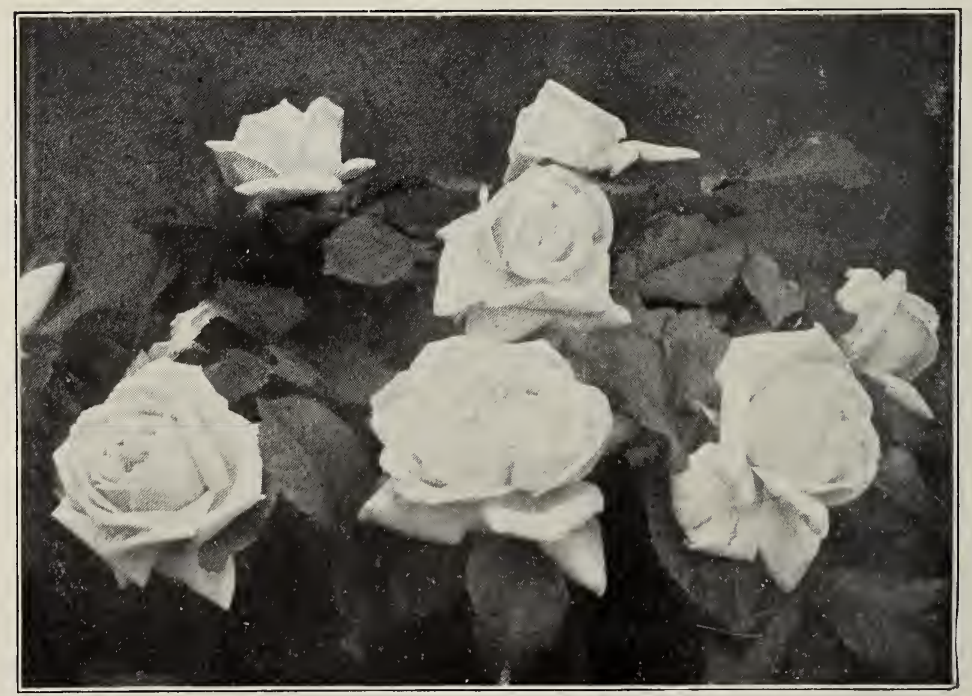

MARGARET DICKSON (See page 9)

Our large list, about 200 varieties, includes only six Tea Roses, which have proven quite hardy. We do not swel: our list by use of tender Teas, and call them Hybrid Teas 


\section{HARDY HYBRID PERPETUAL ROSES, continued}

Fisher Holmes. Shaded crimson-scarlet; very brilliant; large and full.

Francois Michelon. Deep carmine-rose, reverse of petals silvery; fragrant and free bloomer; excellent late in June and July, when other varieties are gone, and also in the autumn.

General Jacqueminot. Brilliant red; velvety, arge and double; fine for inassing.

Grand Mogul. Deep crimson, shaded with scarlet and black.

Gustave Piganeau. Brilliant carmine-lake; very large, full and cupped, opening well; a fine Rose.

Helen Keller. Brilliant rosy cerise; petals large, shell-shaped, and of great substance; flowers large, full, fragrant. Awarded gold medal by the National Rose Society.

Heinrich Schultheis. Delicate pinkish rose, large and fine form; fragrant.

Jean Liabaud. Velvety crimson-maroon; large, full and fragrant.

Jeannie Dickson. Rosy pink, edged with silvery pink; very large, full, highcentered flowers; thick, smooth petals.

John Hopper. Bright rose, with carmine center a profuse bloomer and standard sort.

Jubilee. Rich, pure red, shading to deep crimson and velvety maroon; fragrance strong and lasting.

Jules Margottin. Bright carmine, large and full.

Lady Helen Stewart. Bright crimson-scarlet ; petals smooth and of great substance; highly perfumed. Flowers produced on long stems.

La Rosiere. Marooncrimson, shaded with black; cupped, double and effective.

Lou is Van Houtte. Reddish scarlet and amaranth, circumference blackish crimson; large and full; one of the best; fragrant.

Mabel Morrison. A sport from Baroness Rothschild, which it resembles in many respects. Color white, sometimes tinged with p.nk. In autumn flowers are pale pink

Madam Gabriel Luizet. A delicate and beautiful pink; large and full; cupped and very sweet. Equal to the baroness Rothschild as an exhibition Rose.

Madame Victor Verdier. Rich bright cherry color; large, full fine cupped form; superb; a most effective Rose.

Magna Charta. Bright pink, suffused with carmine; very large, full and of good form; habit erect; foliage rich; very abundant in bloom.

Marchioness of Londonderry. Ivory-xwite; large, shell-shaped petals of great substance; highly perfumed; growth vigorous and foliage very handsome. Awarded a gold medal by the National Rose Society of England.

Margaret Dickson. White, with pale flesh center; large shell-like petals of good substance; form good; foliage handsome, dark green; fragrant.

Marguerite de St. Amande. Bright rose, very beautiful in the bud state. This variety will give more fine blooms in the autumn than almost any other in the class.

Marie Baumann. Brilliant carmine-crimson; large, full, of exquisite color and form; fragrant; extra fine.
Marshall P. Wilder. Cherry-red; large, well formed and very fragrant. Very free bloomer late in autumn.

Maurice Bernardin. Vermilion; large, full and of fine form. Blooms in clusters; very prolific.

Merveille de Lyon. Pure white, sometimes washed with satin-rose; very large, full and cupped; similar to its parent, Baroness Rothschild, but larger.

Mrs. Geo. Dickson. H. P. Delicate soft pink; continuous bloomer.

Mrs. R. G. Sharman-Crawford. Deep rose-pink, outer petals shaded blush; large and of good imbricated form ; one of the most constant, flowering from early summer until late in autumn. Received a gold medal from the National Rose Society of England. One of the finest Roses grown.

Our Roses go to many of the most noted Rosarians in the country. One order alone was $\$ 1,200$. Such orders are

not placed at random

Mrs. Harkness. H. P. A blush sport from Heinrich Schultheis.

Mrs. John Laing. Soft pink, of beautiful form; very fragrant and free-flowering.

Oakmont. Deep bright rose-color; delightful fragrance; continuous bloomer.

Paul Neyron. Deep rose-color; very large, fine form and habit; the largest Rose; very desirable.

Pierre Notting. Blackish red, shaded with violet; very large and full; one of the best dark Roses.

Pride of Waltham. Delicate flesh, nicely shaded with bright rose; very clear and distinct. The flowers are large and full, with petals of great substance.

Prince Arthur. Brilliant rich deep crimson ; large and double; an excellent variety.

Prince Camille de Rohan. Crimson-maroon, rich and velvety; large and full; one of the best old Roses.

Queen of Queens. Pink, with blush edges; large and full, of perfect form and a true perpetual-flowering Rose; distinct and equally good as a garden and exhibition Rose. One of the finest of its color. Gold medal. National Rose Society.

Rev. J. B. M. Camm. Carmine-rose, medium size; one of the most fragrant and free-flowering. size; on
Superb. 
HARDY HYBRID PERPETUAL ROSES, continued

Reynolds' Hole. Maroon, shaded with crimson ; large and of globular form; distinct and good.

Robert Duncan. Flowers large, perfectly formed, bright rosy lake; free bloomer.

Rodocanachi. Soft transparent rose-pink, good form, and fragrant: growth vigorous; a grand Rose.

Souvenir de President McKinley. Flowers large, full, and borne singly on long stems; beautiful rosy flesh, shading to white; a cross from Magna Charta and Captain Christy.

\section{CLIMBING AND TRAILING ROSES}

\section{Select List of Climbing Roses}

Ard's Pillar. See New Roses, page 4

Crimson Rambler. At the head of this list stands the Crimson Rambler, not only for its vigorous growth (making shoots 8 to ro feet in a single season), but also for its brilliant display of crimson clusters of flowers in the greatest profusion. It succeeds everywhere, is perfectly hardy and retains its foliage into the winter. Notwithstanding the fact that this Rose has been on the market several years, the demand is now greater than ever. 767 Climbing Kaiserin Augusta Victoria (Mrs. Robert Peary). A sport from the well-known namesake, from which it has inherited the floriferous and other beautiful qualities, but hardy as a Moss Rose.

2333 Climbing Caroline Testout. Caroline Testout has long held a very high rank among ever-blooming Roses, and this climbing sport bids fair to be as popular. Extra strong two-year plants.

Carmine Pillar. Flowers very large, single, bright rosy carmine grows io to 12 feet in a season.

Climbing Folkestone. $\mathrm{Hy}$. brid Tea. Flesh-color; same excellent qualities as the Viscountess Folkestone.

Climbing Jules Margottin. Carmine-rose; fine in bud and bloom. One of the best. By close pruning may be grown in bush form.

Dawson. This is a cross between the Japanese Rose, Multiflora compacta and General Jacqueminot. It is a wonderfully strong grower, with flowers of a bright carmine, very double, and produced in large, pyramidal clusters.

Empress of China. Flowers of good size, soft red; blooms from June to November. A strong grower and free bloomer.

Gloire de Dijon. Polyantha. Buff, orange center, very large and double, the first to flower and keeps on to the very last: the hardiest of any of the Tea Roses and very sweetly scented. Good in any situation, either as a standard, bush or pillar rose; invaluable for covering walls in any aspect.

2034 Helene. Individual flowers larger than those of Crimson Rambler. Semi-double; color violet-rose, with yellowish white center. Habit fully as strong as the Rambler, but more graceful. 2288 Leuchstern. A new polyantha, producing in great profusion large bunches of cineraria-like flowers; color bright rose, with large white eye: growth and foliage distinct and beautiful; excellent for pyramids. Caused a great sensation at the Temple Flower Show in London.

Rubin. Deep crimson blooms, larger and fuller than Crimson Rambler; beautifully formed; hardy and very vigorous.
Tom Wood. Cherry-red; large, shell-shaped petals of great substance. Flowers freely and continuously from early summer until late in the autumn.

Ulrich Brunner. Bright cerise-red. In all respects a very fine Rose.

Victor Verdier. Rosy carmine, purplish edges; a large, free-growing Rose of good quality and very effective.

Xavier Olibo. Velvety black, shaded with amaranth; large and full.

Setigera. A very popular single flower 3 inches in diameter; blooms just after Crimson Rambler. Very showy and effective.

Now White Rambler Rose, Trier. A stronggrowing climber of the Rambler type, producing immense clusters of pale rose-colored flowers changing to white; a decided improvement on the White Rambler, and blooms throughout the summer and fall.

Zepherine Drouhin. Bourbon. This is an old Rose which is very popular with those who have been fortunate in securing it. It is large, semi-double and of exquisite rose-color; a very strong grower and may be used either as a pillar or bush Rose. Sweet and floriferous.

\section{Wichuraiana and its Hybrids}

This includes some of our most beautiful climbing Roses. The Hybrids crossed with this type, a rampant trailing Rose, and various strong, upright growers, produce vigorous growth and freedom of bloom combined with the beautiful Wichuraiana or evergreen foliage. The foliage is of a leathery texture, a beautiful shiny green. and not only is proof against all insects, but is retained on the plant far into the winter.

Debutante. Beautiful soft pink, double flowers in clusters : fragrance of the Sweetbrier; blooms in July and again in September and October.

Dorothy Perkins. We consider this the best pink climber. rivaling Crimson Rambler in all but color, which is clear shellpink and does not fade. It excels in beautiful foliage, size and fragrance of bloom.

Evergreen Gem. Flowers buff in bud, changing to almost white; 2 to 2 inches in diameter; perfectly double and with the scent of the Sweetbrier; foliage very dense and bronzy.

Farquhar. Undistinguishable from Dorothy Perkins.

Gardenia. Flowers cream, 3 to $3^{1 / 2}$ inches in diameter; delightfully fragrant.

Lady Gay. See page 5

Pink Roamer. A strong grower with clusters of rich pink flowers with almost white center ; orange-red stamens.

Sweetheart. Bright pink in bud, on opening shades to a white; double flower, deliciously fragrant.

W. C. Egan. Flowers large, very full, silvery pink, in clusters.

Wedding Bells. See page 6 . Wichuraiana (Me morial Rose). This is a distinct and valuable low trailing species from Japan. The pure white flowers are produced in profusion during the month of July. It has proved

Sample of our Climbing Roses at right and Gruss an Teplitz at the left. valuable for covering banks, rocks, etc. 


\section{LORD PENZANCE HYBRID SWEETBRIERS}

These are crosses between the conmon Sweet brier and various old-fashioned garden Roses. They are vigorous and perfectly hardy. Foliage is sweet-scented.

Amy Robsart. Deep rose.

Anne of Geierstein. Dark crimson.

Brenda. Peach-color.

Catherine Seyton. Soft rosy pink.

Edith Bellenden. Pale rose.

Flora M'Ivor. White, tinted rose.

Green Mantle. Rose, white center.

Jeanie Deans. Crimson; semi-double.

Julia Mannering. Pearly pink.

Lady Penzance. Coppery yellow.

Lord Penzance. Fawn-color.

Lucy Ashton. White, pink edges.

Lucy Bertram. Crimson, white center.

Meg Merrilies. Crimson.

Minna. White, tinted blush.

Rose Bradwardine. Clear rose.

\section{RUGOSA ROSES AND THEIR HYBRIDS}

A very interesting group from Japan. They are exceedingly hardy, and thrive in almost any soil or situation. They form strong bushes 3 to 4 feet high, furnished with handsome glossy foliage which renders them highly ornamental. They continue to bloom from June to November, after which the bright red seed-pods are striking objects during winter. They make grand shrub effects.

Atropurpurea. The flowers, produced in large bunches, are crimson-maroon, and in the bud state almost blackish crimson.

Belle Poitevine. Rose-color, double, very floriferous and very sweet.

Blanc Double de Coubert. A double white form of Rugosa alba, large and showy; delightfully fragrant. Superb.

Madame G. Bruant. Buds long and pointed, when open semi-double; pure white and fragrant.

Rugosa rubra. A most beautiful bright rosy crimson. Its flowers, borne in clusters nearly all summer, are delightfully fragrant.

Rugosa alba. Same as above, except that color is pure white.

Conrad F. Meyer. Clear silvery rose; large, fragrant flowers; bud well formed; foliage not like Rugosa

Souv. de Pierre Leperdrieux. Bright vinous red flowers double, produced in immense clusters; fruits very ornamental.

\section{MOSS ROSES}

This is a favorite class on account of the beautiful buds, which, for bouquets and cut-flowers, are invaluable. They require close pruning and high culture. The four kinds that follow are considered best sorts.

Crested Moss. Deep pink-colored buds, surrounded with a mossy fringe and crest; a fragrant and very beautiful Rose.

Gracilis. Deep pink, buds beautifully crested.

Salet. Light rose, large, full and beautiful in the bud.

White Bath. The best white Moss Rose.

\section{MISCELLANEOUS ROSES}

Austrian Copper. Flowers single, brilliant, coppery red, outside of petals dull gold; very effective.

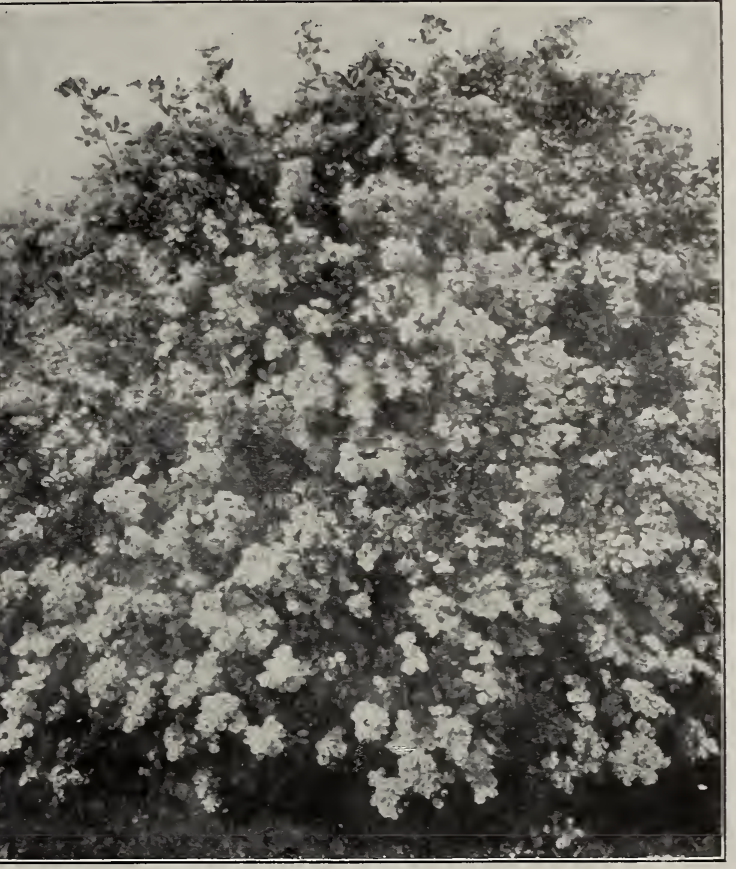

ROSA MULTIFLORA JAPONICA

Cabbage Centifolia (Cabbage Rose). Rose-color; large size, globular form; very fragrant; superb variety.

Coquette des Alpes. W'hite, slightly shaded with carmine; medium size; form semi-cupped; wood longjointed; larger flowers than the others. The strongest grower of its class.

Coquette des Blanches. Pure white, sometimes faintly tinged with pink ; flowers of medium size, somewhat flat, but full and very pretty; growth more bushy and symmetrical than any of the others. One of the hardiest. Later than the rest to flower.

Harrison's Yellow. Fine golden rellow, semidouble; flowers profusely.

Madame Plantier. Pure white; about medium size; full; produced in great abundance early in the season ; one of the best white Roses for hedges.

Mignonette. A splendid variety of Rose for edging beds; deliciously perfumed and constantly in bloom. Dwarf.

Multiflora Japonica. Exceedingly free-flowering, fairly covering itself with great clusters of small white, single, sweetly fragrant flowers. It grows rapidly, and s a valuable shrub.

Persian Yellow. Bright yellow, small, nearly full; like the two above, should be pruned little, as the flowers are produced from the terminal shoots of the old wood, or prune one bush one year, another the next.

Rosa spinosissima. Low shrub with upright branches; 3 to 4 feet high. Foliage is small and dark; flowers single, pure white or pink; a very persistent bloomer during a large portion of the summer, followed by deep black heps or seed-pods during the winter. Being exempt from insect pests and perfectly hardy; it should be freely planted.

Rubiginosa. Sweetbrier. Eglantine. Dense shrub attaining 6 feet. Flowers bright pink, $\mathrm{I}^{\mathrm{I}} / 2$ to 2 inches in diameter; heps ovoid, orange-red or scarlet ; a handsome hardy Rose of compact habit, whose foliage exhales a very agreeable, aromatic odor.

"The Proof of the Pudding," Two years since a customer asked us to send him I50 Roses, our The Proof of the Pudding. selection. He has since ordered orer 300 , and two of his nearest neighbors have ordered over 500 the past year. This kind of advertising pays well, since its only cost is select stock, well packed and shipped at the proper time, together with cultural directions when desired, which is no more than every customer has a right to expect. 


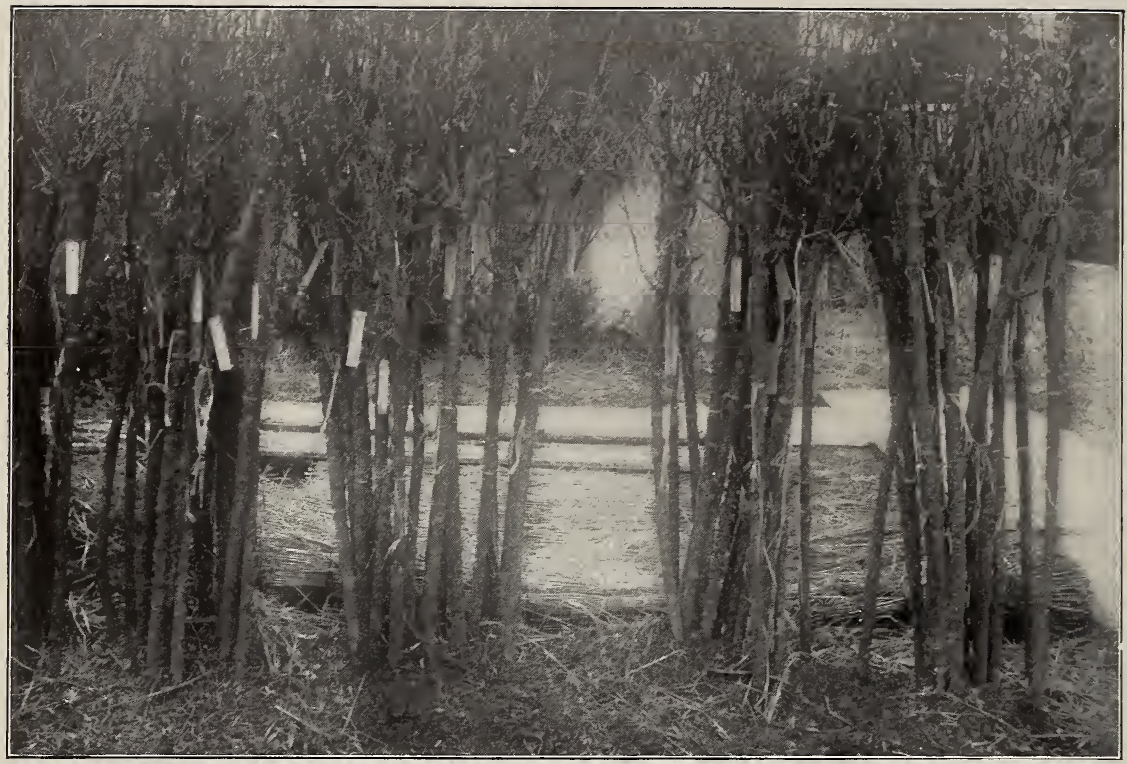

PART OF AN ORDER FOR 25O TREE ROSES FROM AN OLD CUSTOMER

\section{ROSES IN STANDARD OR TREE FORM}

Roses in tree form are among the most showy of plants. Stock grown on Rugosa and Canina has proven so successful in our trying climate that we have this season prepared to furnish larger numbers than ever of tree ramblers and other choice varieties. Their great vigor may be seen from the accompanying cut of a Rambler from a photograph, June, I903, of a plant set in April, I902. The stems are sufficiently strong and heavy to stand without staking. We offer these tree Roses in many varieties of Hybrid Teas and Hybrid Perpetuals.

Crimson Rambler in Tree Form. The accompanying photo-engraving of Tree Rambler gives but a faint idea of the mass of crimson bloom. We offer these plants in 2-, 3- and 4-year sizes on Rugosa.

Dorothy Perkins and Farquhar in Tree Form. Our customers have been so much pleased with Crimson Rambler in tree form that we have this year pre-

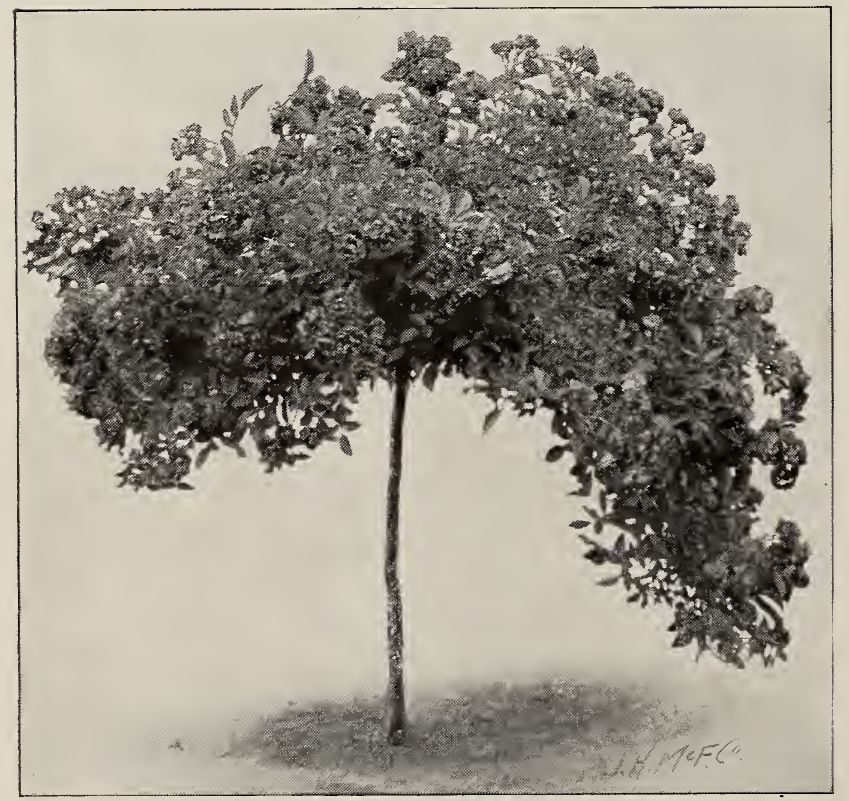

CRIMSON RAMBLER, STANDARD OR TREE FORM pared a fine stock of two other climbing Roses as standards. These are on strong Rugosa stems and will produce a magnificent effect.

Standard Baby Rambler. The continuous bloom and perfect hardiness of this beautiful Rose has made it very popular. We are pleased to announce that we can supply a limited number of plants on Rugosa.

Frau Karl Druschki. No collection of standard Roses is complete without the best white Hrbrid Perpetual. In foliage and flower this Rose is unexcelled. Its heavy white petals surrounded by a mass of beautiful green foliage makes each Rose a bouquet in itself.

\section{OTHER STANDARDS}

We offer many varieties, among which are the following:

\section{Alfred Colomb \\ Antoine Rivoire}

Baroness Rothschild

Clio

Caroline Testout

Captain Christy

Gloire de Dijon

Gruss an Teplitz

Gustave Grunerwald

General Jacqueminot

Helen Gould

Jules Grolez

Killarney

Maman Cochet

Magna Charta

Mrs. R. G. Crawford

Mrs. John Laing

Marie Baumann

Malmaison

Paul Neyron

Prince Camille de Rohan

Ulrich Brunner

White Baroness 


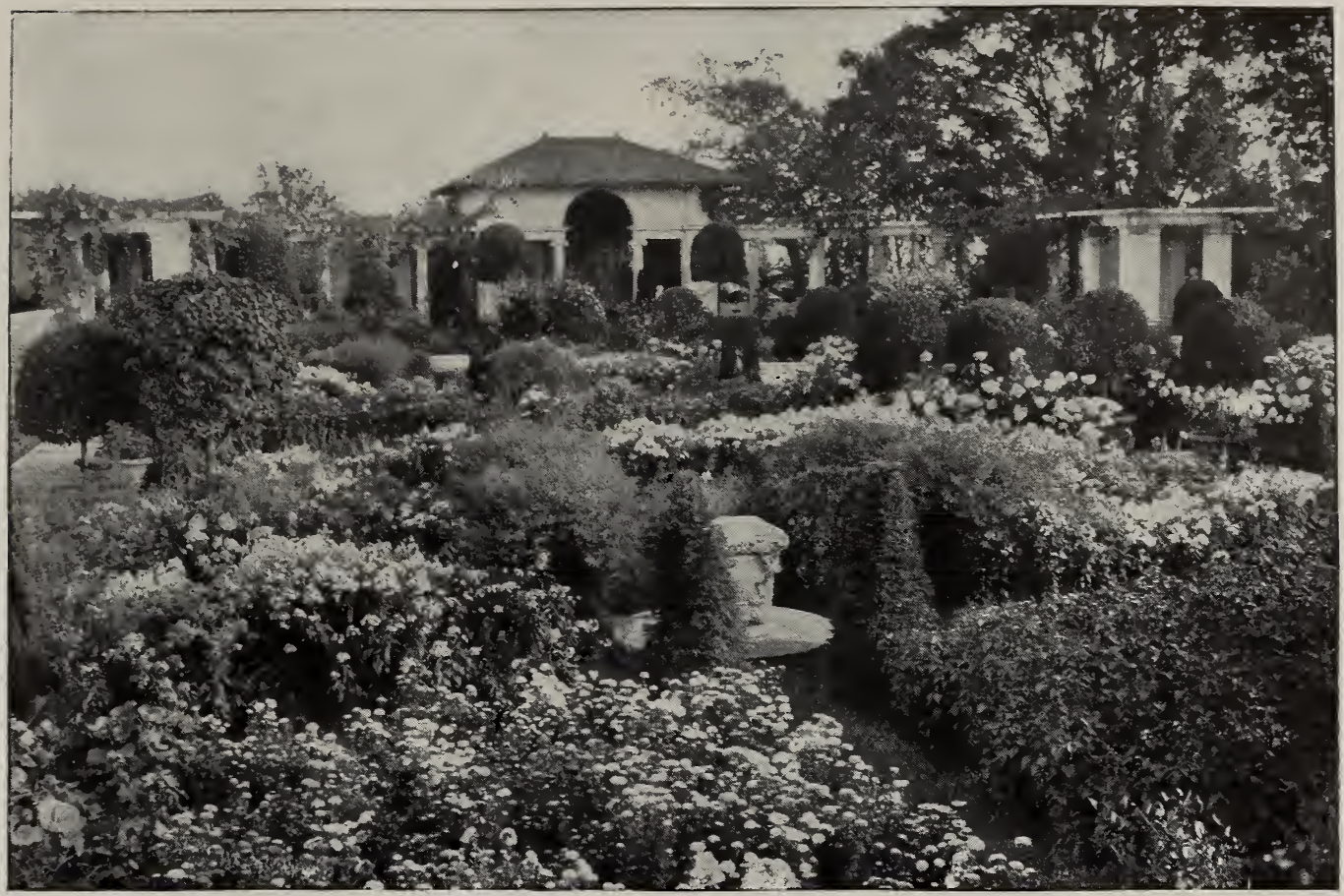

\section{"My Grandmother's Garden"}

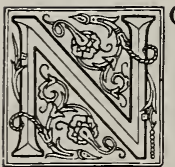

O home ground is complete without a collection of hardy herbaceous perennials. These flowers are deservedly becoming more popular every year. By proper selection, one may have flowers in abundance from April to November, and a pleasing picture by proper arıangement for color effect. The plants may be arranged in formal designs or along the shrubbery border. They bloom so freely that one may cut and come again, and are so easily grown that any one may succeed with them. Noreover, the cost need deter no one from having a choice selection, since the plants are permanent and large enough to bloom freely, and quite inexpensive. Bulbs, especially daffodils, were always seen in the old gardens, and what can give more pleasure, simply for the planting? The early and late varieties give a succession of bloom fully six weeks, and planted among those varieties of herbaceous flowers which start late in spring, a succession may be had throughout

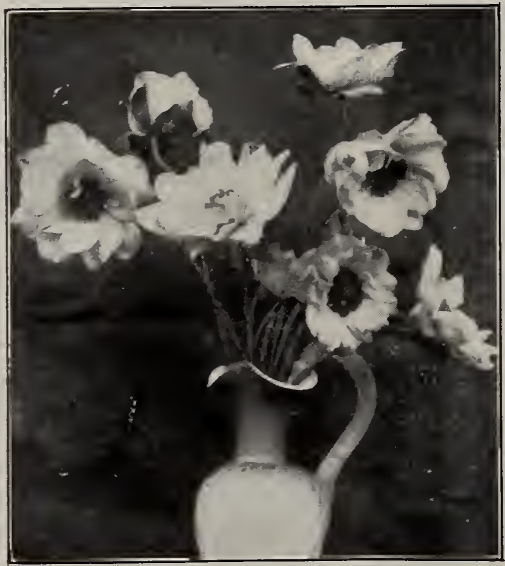

ANEMONE, QUEEN CHARLOTTE the season. Left from year to year, the tulips and narcissi would flourish just as they used to do in the old gardens. The varieties of flowers known to our grandmothers were comparatively few, comprising, however, some of the hardiest and best still in use. To these have been added many beautiful forms discovered and originated during the past few years (thanks to such men as Luther Burbank), until there are now offered thousands of varieties. The task, therefore, of selecting the varieties suitable for rock wild, or ordinary flower-garden is no easy one. Many herbaceous plants are mere weeds. The list offered below has been carefully selected and comprises most of the varieties of real value.

Designs for proper arrangement of plants to give pleasing effects furnished at moderate cost. We have given attention to the matter of old-fashioned flowers a number of years, believing them far superior to the ordinary bedding plants. We have furnished many of the finest estates with plans and plants. 


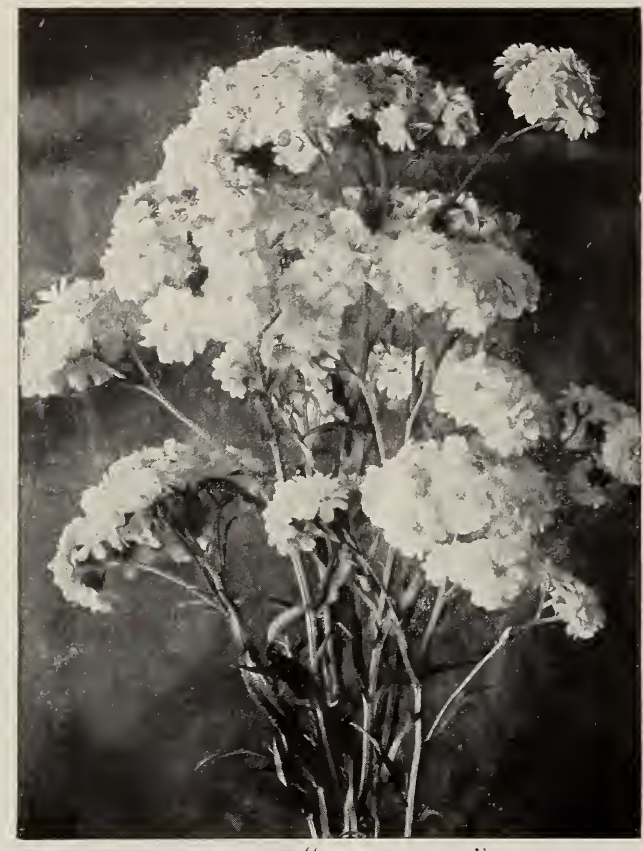

ACHILLEA, "THE PEARL

ACANTHUS. Bear's Breech. A stately decorative plant for sub-tropical effect; spikes of curious Howers appearing in August and September.

mollis. Deeply toothed heart-shaped leaf I foot wide, 2 feet long; flowers rose-colored.

mollis latifolius. Variety of the above with larger and heavier foliage; an interesting plant.

ACHILLEA Ptarmica fl. pl. "The Pearl." Milfoil. Dense masses of flowers from June to October, 2 feet high, of purest white.

Millefolium roseum. Rosy Milfoil. Finely cut, deep green foliage; flowers pink, in dense heads 2 feet high; flowers all summer.

ACONITUM. Monk's Hood. Tall and handsome herbaceous plant about 3 feet high, excellent for naturalizing in copses, shrubbery or beside streams.

Napellus. Large, dark blue flowers; May and June.

ACTAEA. Baneberry. A desirable native plant, with showy, dense spikes of white flowers, about 2 feet high, produced in masses in June, followed by handsome clusters of berries.

spicata alba. Pure white berries on red stems.

rubra. Bright scarlet berries in long, dense spikes.

ADONIS vernalis. Bird's-eye. One of the prettiest and earliest of spring planting perennials; about I2 inches high; effective in rockwork or in border; flowers clear yellow.

AEGOPODIUM Podagraria variegata. Bishop's IVeed. Rapid-growing plant with neat green and yellow variegated foliage. As it thrives in any soil, it is excellent for covering waste or barren spots; also useful for a border plant.

AGROSTEMMA. Rose Campion. Stout, erectgrowing plants with silvery foliage, which contrasts well with the showy flowers.

Coronaria. Mullen-pink flowers on stems $2 \frac{1}{2}$ to 3 feet high.

Flos Jovis. Deep pink flowers on 12 -inch stems.

AJUGA. Bugle. Useful plant for carpeting the ground particularly in shady positions where grass will not grow. Also useful for rockery ; flowers in May.

Genevensis. Bright, blue flowers, in long, dense, showy spikes.

reptans rubra. Large spikes of purplish blue flowers.
ALYSSUM saxatile compactum. Golden Tuft. This is one of the best plants for rockery, growing one foot high and producing early in summer masses of very flat heads of bright yellow flowers. Saxatile compactum fl. pl. Beautiful new doubleflowering form with bright golden yellow flowers in masses; form of the above; pretty and distinct.

ANEMONES, Double and Single. Among the finest flowers for masses of bloom or for cutting. Some of the flowers are 4 inches across. They bloom in great profusion from September to November. 2 to 3 feet high.

Japonica. Carmine, with yellow center.

Japonica alba. A fine large pure white.

Queen Charlotte. Large, semi-double flowers of La France rose-pink, a color as rare among flowers as it is beautiful.

Whirlwind. A pure white semi-double variety.

ANTHEMIS tinctoria. Of dense, bushy habit and large, yellow flowers.

tinctoria Kelwayi. Similar to the above, but with deeper yellow flowers.

ANTHERICUM Liliastrum. St. Bruno's Lily. At beautiful plant 2 feet high ; foliage grass-like; flowers white, fragrant and lily-like, in spikes in June.

AQUILEGIA. The Columbines are old favorites that succeed in any garden; they are beautiful in flower and foliage. The following are the best:

California Hybrids. A grand mixture.

Canadensis. Our native Columbine; bright red and yellow.

chrysantha. The beautiful golden-spurred variety. caerulea. Rocky Mountain Columbine. Blue and white. One of the handsomest of the family.

Skinneri. Scarlet with greenish tips; very distinct.

ARABIS alpina. Rock Cress. One of the most desirable of the very early spring-flowering plants ; especially adapted for edging and for the rock garden, forming a dense carpet covered with pure white flowers; requires rather dry soil.

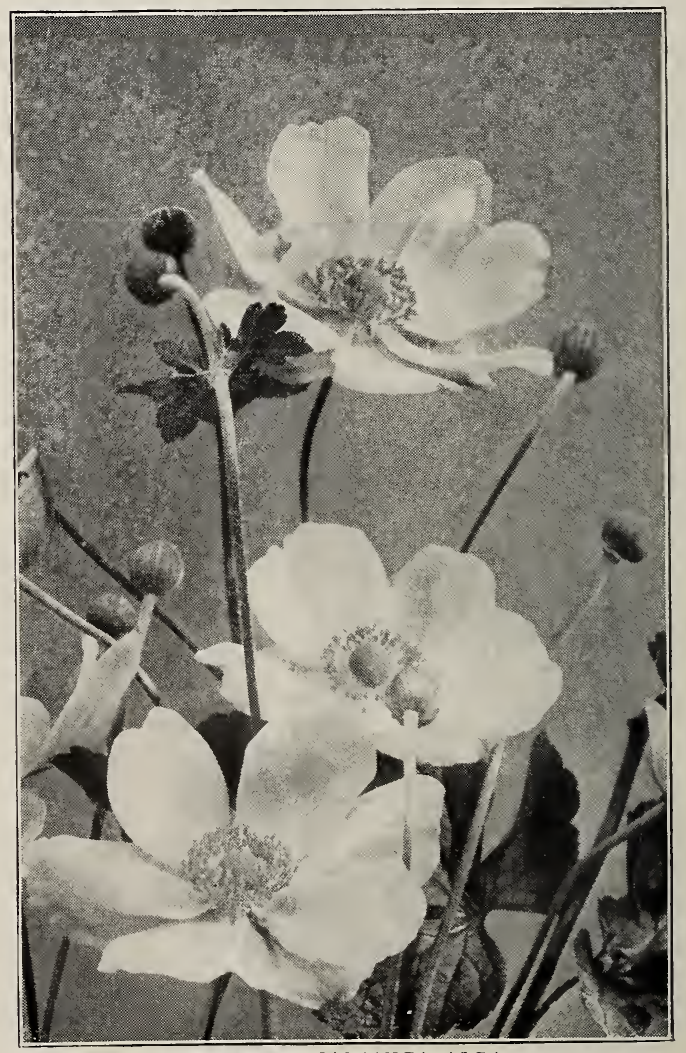

ANENONES JAPONICA ALBA 
ARENARIA. Sandwort. Close-growing evergreen plants, forming a dense carpet of verdure; especially desirable for rockwork.

caespitosa. Dense, moss-like foliage; white flowers in spring.

ARMERIA. Thrift. Attractive dwarf evergreen plant about 9 inches high, flowering more or less continuously the whole season; indispensable for rockery and border.

Laucheana. Bright rose-colored flowers.

maritima splendens. Bright rosy pink.

maritima alba. A pretty white.

ARTEMisia Stellariana. Old Woman. Deeply cut silvery foliage, much used in carpet bedding. Ther bear the shears well and can be kept down to 5 or 6 inches if desired.

ASCLEPIAS tuberosa. Butterfly IVeed. One of the showiest of our native perennials; about 2 feet high; blooms from July to September; close, compact heads and brilliant, orange-colored flowers.

ASTILBE. Goat's Beard. Herbaceous Spirea. One of the most beautiful flowers in cultivation. They like partial shade; fine for cutting.

astilboides floribunda. White flowers; compact and graceful.

Japonica. The old favorite.

compacta multiflora. A variety much used for greenhouse growing.

Gladstone. Large white, new

palmata elegans. A free-flowering silvery pink form.

ASPHODELUS luteus. Asphodel. An effective border plant with sword-like spikes of fragrant yellow flowers 3 feet high. July and August.

ASTERS, HARDY. The first four varieties are lowgrowing and indispensable for the rockery.

alpinus. Flowers bright purple; 8 inches in height; blooms in June.

alpinus albus. Same as the above except the flow ers, which are white.

Amellus elegans. Light blue, large flower in August: I to I $1 / 2$ feet.

cassubicus. Flowers light lavender, covering the plant completely; August ; 2 feet.

The following are late-flowering; fine for massing in shrubberies and borders

grandiflorus. Very fine; flowers often measure 2 inches in diameter; violet-blue; very late.

Lady Trevelyn. Large heads of white flowers with yellow centers; very ornamental; 3 to 4 feet.

Laevis. Blue flowers; large ; early; 3 to 4 teet.

Novae-Angliae. New England Aster. Bright violetpurple: 4 feet.

Novae-Angliae roseus. A charming variety of the above, with all shades of rose and crimson. Most beautiful of all hardy Asters. Will not endure much shade. 3 to 4 feet.

T. S. Ware. Lilac-mauve; $3^{1 / 2}$ feet.

Madame Soyneuse. Pale lilac; very free.

Ptarmicoides. Pure white; August and September; very distinct; choice for cutting.

AUBRIETIA. Rock Cress. Pretty, dwarf-growing; excellent for rockery or dry sunny places; flowers early in spring and continues a long time. Of this genus Dr. Robinson says: "If there were only one family of rock plants known to us, this which gladdens the rocks of Greece and all near countries with its soft colors in the dawn of spring, would be almost enough to justify the lovers of rock plants for any extravagance in their behalf. In these plants, all difficulties of culture, increase, soil, etc., fly away. There is hardly a position selected for rock planting that may not be graced by them."

deltoidea. Flowers light lavender; 3 to 4 inches.

Campbelli. Deep violet-blue.

Hendersoni. Rich purplish violet.

Graeca. Large; lavender; white eye.

BELLIS perennis. English Daisy. Double-flowering; white and pink.

BELLFLOWER, or BLUEBELLS. See Campanulata and Platycodon.

BLOODROOT. See Sanguinaria.
BOLTONIA. False Chamomile. Among the showiest of our perennial plants, with large single, asterlike flowers. The plant is in bloom during the summer and autumn months, and, with its thousands of flowers open at one time, it produces a very fine effect.

asteroides. Pure white; very effective

latisquama. Pink, slightly tinged with lavender.

BAPTISIA australis. False Indigo. Handsome foliage; dark blue lupin-like flowers in racemes I to 2 feet long.

tinctoria. Produces spikes of bright yellow flowers during June and July.

BUPHTHALMUM salicifolium. Ox-eye. A showy ormamental, hardy perennial with yellow flowers during July and August.

CAMPANULA. Bellflower. Elegant genus; rich in color, profuse in bloom and of easy culture.

persicifolia. Peach Bells. Grows I $1 / 2$ to 2 feet high and produces an abundance of blue, salver-shaped flowers during June and July.

alba. A pure white form of the above.

gigantea Moerheimi. A giant new sort with large spikes of double flowers 2 to $2 \frac{1}{2}$ inches in diameter. Blooms from the last of Mar to late in July.

pyramidalis. A most striking plant for the border a perfect pyramid 4 to 5 feet covered with large blue flowers in September.

rotundifolia. Bluebells of Scotland. This is the true Harebell or Bluebell famed in song and story: with beautiful clear blue flowers from June to August. I2 inches.

Medium. Canterbury Bells. Cup and saucer Canterbury Bells. Without doubt this is the finest trpe of the old-fashioned, much-prized garden plant.

Medium roseum. Delicate rosi pink.

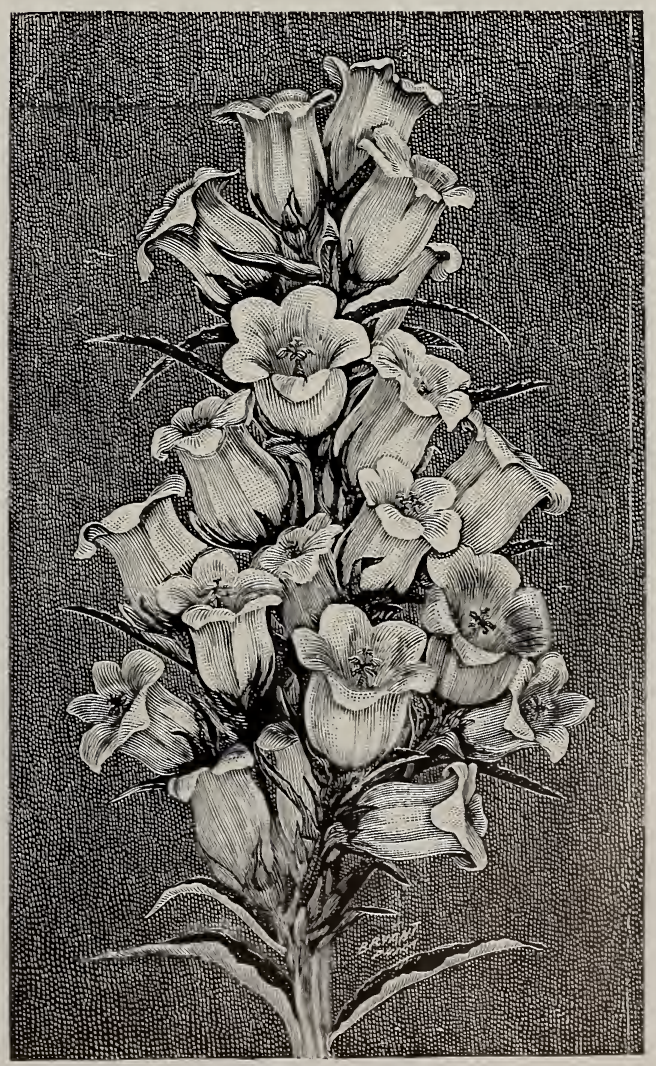

CAMPANULA MEDIUM 
CARYOPTERIS Mastacanthus. Blue Spirea. A choice, hardy perennial growing 2 feet high, and producing rich, lavender-blue flowers in great profusion the whole length of its branches, from $\mathrm{Scp}$ tember until frost.

CERASTIUM tomentosum. Snow-in-Summer. A desirable dwarf plant covered with small white flowers. Its silvery foliage makes it very attractive in the rockery or for carpeting dry, sunny spots; also used with good effect in carpet bedding.

CHRYSANTHEMUMS, HARDY POMPON. One of the most popular plants now used in flower gardens because of their October and November bloom in great profusion, after frost has withered all other flowers.

Baby. A miniature flower; color lemon-yellow.

Dundee. Maroon shaded scarlet.

Flora. Beautiful deep golden yellow.

Fred Peele. Deep crimson, tipped gold.

Golden Pheasant. Rich golden vellow; fine form.

Golden Fleece. Clear yellow.

Goldfinch. Golden yellow, striped red.

Queen of Bulgaria. Rose-crimson.

Model of Perfection. Ball-shaped, clear white.

Rhoda., Delicate apple-blossom pink.

Eagle d'Or. A fine golden yellow.

Souer. Melaine. Large, double white.

Julia Lagravere. Clear velvety carmine, shaded rich garnet.

L'Ami Couderchet. .Sulphur-white; fine.

President. Rich crimson, of perfect shape.

Princess of Wales. A fine white.

Regulus. Terra-cotta or dark tan.

Rosinante. Blush rose; very dwarf.

Gold Nugget. Golden yellow, inner petals tinged with red.

Isabella. Delicate shell-pink, passing to white in the center.

Globe d'Or. Clear lemon-yellow, deeper towarà the center.

Trojan. Maroon, with yellow center.

Tiber. Crimson-brown, tipped yellow.

Veuve Cliquot. Brick-red, edged yellow.

CHRYSANTHEMUM. Moonpenny Daisy.

maximum, Triumph. A strong-growing perennial about 2 feet in height, which continues in bloom from Juiy until October; flowers daisy-like, 3 to 4 inches in diameter, with a golden center; of great substance, lasting a week or more when cut

maximum, Perfection. A strong grower with large white flowers all summer and fall.

Shasta Daisy. Large, snowy white flowers 4 inches across; in bloom throughout the summer and fall.

Chelone. Shell-Flower. Stately, handsome perennials growing 2 feet high and bearing numerous spikes of large flower-heads during the summer and fall.

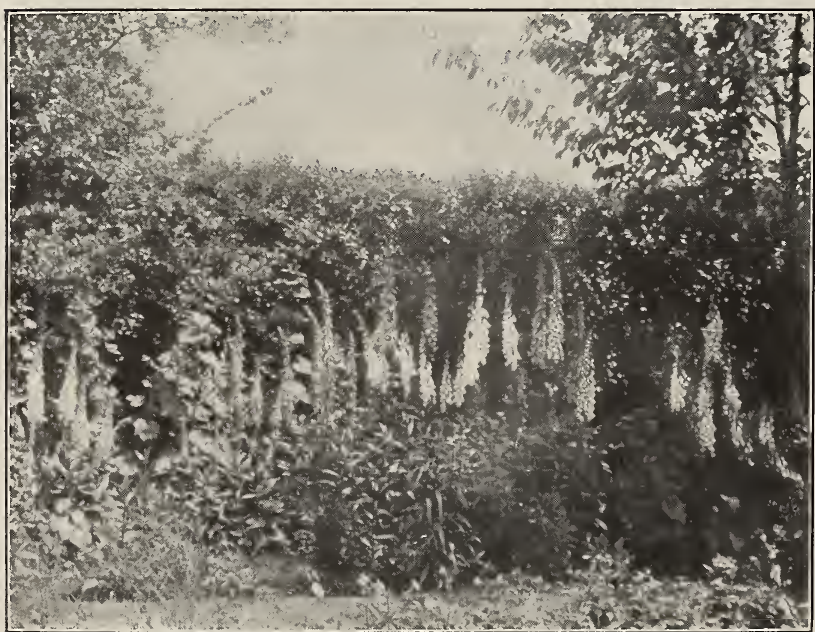

DIGITALIS
Chrysanthemum glabra. Terminal spikes of large pink flower-heads.

alba. Same as above, with creamy white flowers.

Lyonii. Heads of deep red flowers; very fine.

CIMICIFUGA simplex. Snakeroot. Valuable on account of its extra late flowers, beginning in September and gaining perfection about the middle of October. Its flower-stems are $2^{1 / 2}$ to 3 feet high, terminating with a dense spike of white flowers which last a long time when cut.

Dahurica. Large spikes of creamy white flowers in September. $3^{1 / 2}$ feet high.

CLEMATIS, SHRUBBY. This type of Clematis is deserving of the greatest popularity, and should be in every collection. They form bushes 2 to 3 feet high and during their long bloom are very attractive.

Davidiana. A most desirable variety with fresh, bright green foliage and tubular, bell-shaped flowers; very fragrant; erect habit. August and September.

recta. Another fine variety with handsome, pure white flowers. June and July. They are very attractive during their long period of bloom, followed by hairy-like seed capsules. 3 to 4 feet.

CONVALLARIA. Lily-of-the-Valley. One of the charming spring flowers. We offer very strong clumps which will give twelve to twenty spikes of bloom the next season after planting. Plant in autumn.

COREOPSIS lanceolata grandiflora. One of the most popular hardy plants. The flowers are a rich golden yellow, of graceful form and invaluable for cutting; the main crop comes during the latter part of June, but it continues in bloom, more or less, the entire summer and autumn. It succeeds everywhere.

rosea. Finely divided, dark green foliage, and producing through August and September numerous small pale pink flowers; useful in the border or rockery. I foot.

DELPHINIUM. Hardy Larkspur. What is more graceful in the flower garden than the delicate blue Larkspur? Bold, attractive and perfectly hardy, it is of the easiest culture and will establish itself in almost any garden soil. Plant early in the spring in deep soil in a sunny position. Cut out the old flower-spikes as soon as through flowering and a succession of bloom will be the result.

Belladonna. Probably the finest of this fine family ; beautiful sky-blue flowers, always in bloom. 2 to 3 feet.

Chinensis. Grows about 18 inches high, and has large open panicles of handsome flowers in all shades of light blue to white.

elatum. Blue, with dark center.

Erskine Park Hybrids. These choice hybrids were developed from a number of the best English varieties grown by E. J. Norman, of Erskine Park, Lenox, and are sure to please all who see them. They are the most vigorous in growth we have seen, and give a profusion of bloom unsurpassed by any.

formosum. The old favorite dark blue variety; grows 3 to 4 feet high, and is in flower almost continuously from June to frost.

formosum coelestinum. A new variety of Formosum, of light color and an exquisite celestial bloom.

DIANTHUS barbatus. Sweet IVilliam. Choice strain of mixed colors. IVe alsooffer a strain of dark crimson.

deltoides. Maiden Pink. A low-growing, creeping variety with pink and white flowers; fine for rockery.

arenarius. Sand Pink. A single-flowering variety of the common garden pink; very sweet.

plumarius semperflorens. These are the old favorite hardy garden Pinks, bearing sweet, clove-scented flowers in May and June. 
Dianthus, Standard Sorts-

Her Majesty. Flowers of large size and purest white.

Homer. Rich rosy red with dark center.

Juliette. White, laced crimson.

Souv. de Salle. Soft rosy pink.

Dianthus, New Everblooming Sorts. These bloom from the latter part of May until fall. Sweet and spicy.

Comet. Bright rosy crimson.

Delicata. Soft delicate rose, finely fringed.

White Reserve. Nicely fringed; pure white.

Napoleon III. Double, brilliant blood-crimson, delightfully clove-scented.

DICENTRA. Bleeding-Heart. Combines a fernlike grace with the flowering qualities of a good hardy perennial.

DICTAMNUS. Gas Plant. Very showy border plants with fragrant foliage; spikes of curious flowers during June and July.

Fraxinella. Showy, rosy pink flowers; deeper veins,

Fraxinella alba. Pure white.

DIGITALIS. Foxglove. These well known plants give a wealth of bloom in June and July; are very effective in shrubbery and other half shady places. See cut on opposite page from a photograph in a celebrated Newport garden.

ambigua, or grandiflora. Showy flowers of pale yellow, veined brown. July and Áugust.

gloxiniaeflora. Very ornamental; color of the flowers varying from pure white to deep pink. We offer these in white, purple, lilac, rose and mixed colors.

lanata. Corolla gray; lip creamy white.

DORONICUM excelsum. Leopard's Bane. No plant is more effective than this for early bloom. Orange-yellow flowers 3 to 4 inches in diameter, on stems I8 to 20 inches long.

DRABA alpina. Very pretty, dwarf, compact alpine plants admirably adapted for the rock garden or front of a sunny border; flowers yellow.

borealis. Whitlow Grass. Very dwarf-growing rock plant; covered in early spring with small yellow flowers.

ECHINOPS. Globe Thistle. These plants are for naturalization in wild gardens and shrubbery. An English gardener with an eve for the picturesque recommends massing them against a background of such boldly contrasting vellow or white flowering plants as Helianthus multiflorus. They make excellent companions for the blue-stemmed eryngiums.

Ritro. Handsome, thistle-like foliage, with globular metallic-blue flowers; 3 to 4 feet high.

sphaerocephalus. Similar to the above, with blue flowers ; 2 to 3 feet high.

EPIMEDIUM. Barrenwort. Bishop's Hat. Dwarf plants with creeping trunks and leathery foliage, which assumes the most beautiful tints of color in autunin; they like peat and shade.

alpinum. Pretty foliage, with airy clusters of yellow flowers unique in form: blooms in spring.

muschianum. Clusters of deep rose-colored flowers.

ERIANTHUS. See Grasses.

ERIGERON. Flea Bane. Blooms much earlier than the aster, growing in tufts like the English daisy from 9 inches to 2 feet high. They do best when somewhat shaded from the midday sun.

speciosus. This is the most popular species: flowers large, purplish blue, with yellow center; July to September.

speciosus major. A variety with larger flowers than the preceding.

glabellus. Large, purplish violet flowers, from July to September: height, 6 to 20 inches.

ERINUS alpinus. A rery dwarf alpine plant forming a beautiful tuft of foliage close to the ground and producing bright rosy purple flowers early in June; excellent for the rockery.

ERYNGIUM. Sea Holly. Handsome ornamental plants from 2 to 3 feet high ; well suited for borders, woodland, wild gardens, etc. The flower-heads, which are produced from July to September, are useful to cut for vases or tọ dry for winter bouquets.

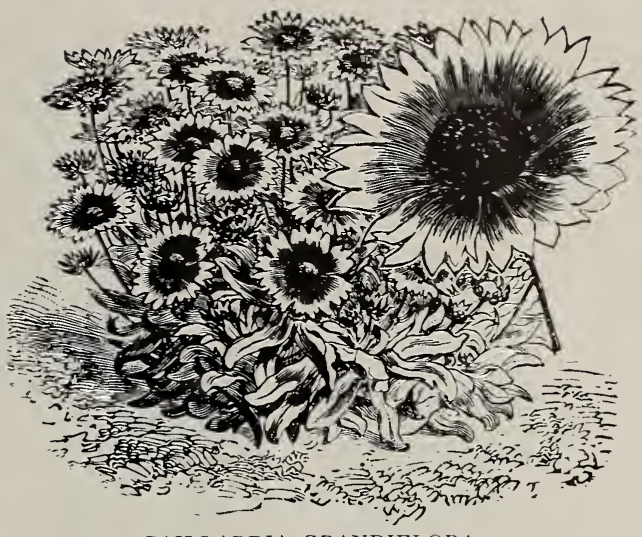

GAILLARDIA GRANDIFLORA

Eryngium amethystinum. The finely cut, spiny foliage and beautiful thistle of amethyst-blue make this a very ornamental plant.

yuccaefolium. Yucca-like foliage and heads of greenish white flowers.

EULALIA. See Grasses

EUPHORBIA corollata. Flowering Spurge. A showy and useful plant, growing is to 24 inches high: flowers pure white; fine for bouquets; June to August ; desirable for cutting.

FERNS. See page 26.

FEVERFEW. Little Gem. Large, double white flowers; June to October; I2 to is inches high.

FORGET-ME-NOT. See Myosotis.

FOXGLOVE. See Digi alis.

FUNKIA. Plantain Lily. The different species are free-flowering, with spikes of bell-shaped flowers, but the chief value is in the foliage.

caerulea. Blue flowers, broad green leaves.

subcordata grandiflora. Pure white, lily-shaped, large, fragrant flowers in clusters. This Day Lily is very attractive in bed or border.

undulata media picta. Green and white variegated foliage; purple flowers.

Thos. Hogg. Broad, glaucous foliage, white border.

GALTONIA(Hyacinthus) candicans. See Autumn Catalogue.

GAILLARDIA grandiflora. Blanket-Flower. One of the most effective and showy hardy flowering plants; beginning to flower in June they continue one mass the entire season; they will thrive in almost any soil, but respond freel $y^{*}$ to liberal treat ment. One flower is often a combination of yellow, orange and deep crimson.

GENTIANA. The Gentians. Some of the gems of the alpine garden are found among the Gentians. They are hard to cultivate and impatient of dis turbance.

acaulis. This is an alpine variety which forms a cushion of glossy dark green foliage surmounted with erect, bell-shaped flowers of intense blue. April to June. This is the flower so celebrated by tourists in the Alps, and is by far the most popular kind in cultivation.

Andrewsii. Blue Gentian. A pretty native species from New England, growing about 2 feet high. Flowers blue, appearing in autumn.

GERANIUM sanguineum. Crane's-bill. Desirable for rockery or border: foliage compact: about is inches high; has bright crimson-purple flowers.

GEUM. Avens. Pretty border plant growing about IS inches high, and producing bright colored flowers during the greater part of the summer and fall. atrosanguineum. Large dark crimson flowers. coccineum plenum. Flowers double, of a bright dazzling scarlet and very showy.

GLECHOMA variegata. Ground Iry. A most useful variegated creeper for banks and the rockery. April and May. 
GLOBE FLOWER. See Trollius.

GLOBULARIA trichosantha. A very pretty dwarfgrowing plant suitable for a shady position in the rockery. In July and August produces an abundance of blue, daisy-like flowers.

GYPSOPHILA. Baby's Breath. These beautiful flowers of easiest culture delight in open, rather dry places; they are especially desirable for rockwork; also good for covering unkempt places with a mass of delicate bloom.

cerastioides. A most useful variety for the rockery, growing but 3 inches high and producing from June to August small white flowers marked with pink.

paniculata. A very elegant light and graceful peren-

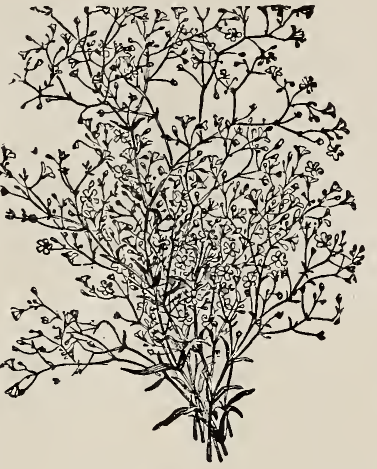

GYPSOPHILA bloom during August and September it forms a symmetrical mass, 2 to 3 feet in height, of minute pure white flowers, forming a beautiful gauze-like appearance. Excellent for cutting.

repens. An excellent trailing plant for the rockery, with clouds of small white flowers.

GRASSES, Hardy Ornamental. These make very attractive groups.

Arundo Donax. A massive variety, growing to a height of 12 feet.

Arundo variegata. A beautiful variegated form of the above. Foliage creamy white and green grows 6 to 8 feet.

Erianthus Ravennae. Grows 9 to 12 feet high frequently throwing up 30 to 50 flower-spikes. Closely resembles the Pampas Grass.

Eulalia gracillima univittata. Compact in habit narrow foliage, bright in color, with a silver midrib.

Eulalia Japonica variegata. A very ornamental variety, striped green and white and often yellow ; flower stalks 4 to 6 feet high.

Eulalia Japonica zebrina. Zebra Grass. The long blades of this variety are marked with bright yellow bands across the leaf.
HELIANTHUS. Hardy Sunflower. Where large borders are planted the perennial Sunflowers are among the most effective hardy plants. They are admirably free-flowering, succeed in any soil, and are fine for cutting.

Soleil d'Or. Deep golden yellow; quilled petals, similar to those of the dahlia; 4 feet; August and September.

multiflorus fl.pl. Double, hardy Sunflower. Flowers in great profusion during July and August ; one of the best.

multiflorus maximus. Gigantic single variety, growing 5 to 6 feet high, surmounted by single golden yellow flowers; August and September.

Maximiliani. The latest of all, perfecting its fine golden yellow flowers in long, graceful sprays in October, when all otlers have finished flowering; fine for cutting.

rigidus. One of the most desirable of our native varieties, beginning to bloom early in July and continuing until fall; flowers golden yellow, with dark centers; 3 feet.

Wolley Dod. The best of the September-flowering varieties; deep yellow flowers; distinct.

HELIANTHEMUM vulgaris. Rock, or Sun Rose. Exceedingly pretty, low-growing evergreen plant, forming broad clumps which are quite hidden with a mass of bloom during the summer months; fine for the front of the border or the rockery.

HELENIUM autumnale. Sneezewort. Deep golden yellow flowers. August and September. 5 to 6 feet. \$I.5O per doz.

Hoopesii. Bright orange flowers; 2 to 3 feet, in July and August. \$1.50 per doz.

HELIOPSIS Pitcheriana. Orange Sunflower. Growing 2 io 3 feet high, and a perpetual bloomer; deep golden yellow, about 2 inches in diameter; very graceful for cutting.

scabra major. Grand improvement on Heliopsis scabra, with large deep orange-yellow flowers, which are produced during the entire season; $3 \mathrm{ft}$.

HEMEROCALLIS aurantiaca major. Yellow Day Lily. New. Japanese variety, with brilliant orangeyellow flowers. Not so hardy as the other sorts.

flava. Few plants can be grown with so little trouble in the border and give such a valuable return as this one. It is so fragrant that it is sometimes called the yellow tuberose. The beautiful light green foliage curving gracefully is suitable for banks. Heavy plants.

Florham. Large, vellow, sweet-scented flowers during June and July; one of the best.

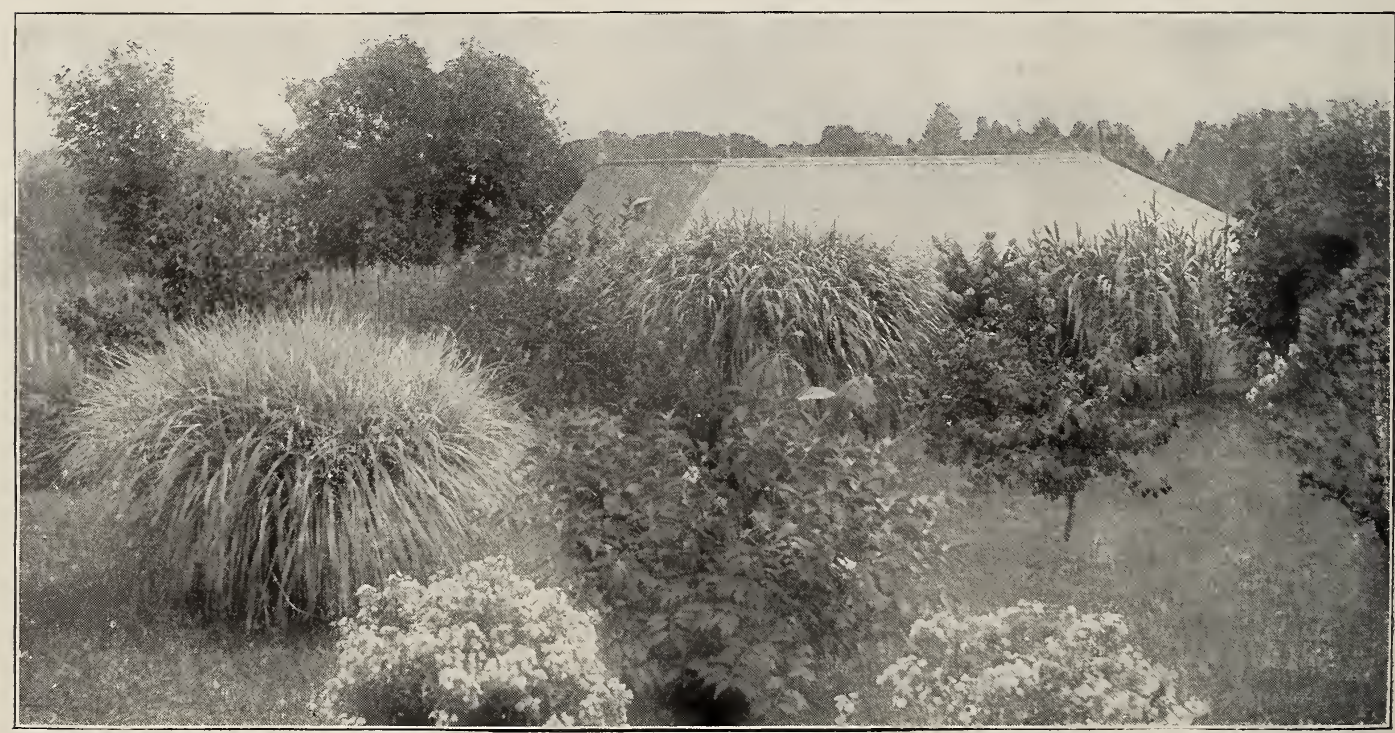

HARDY ORNAMENTAL GRASSES 


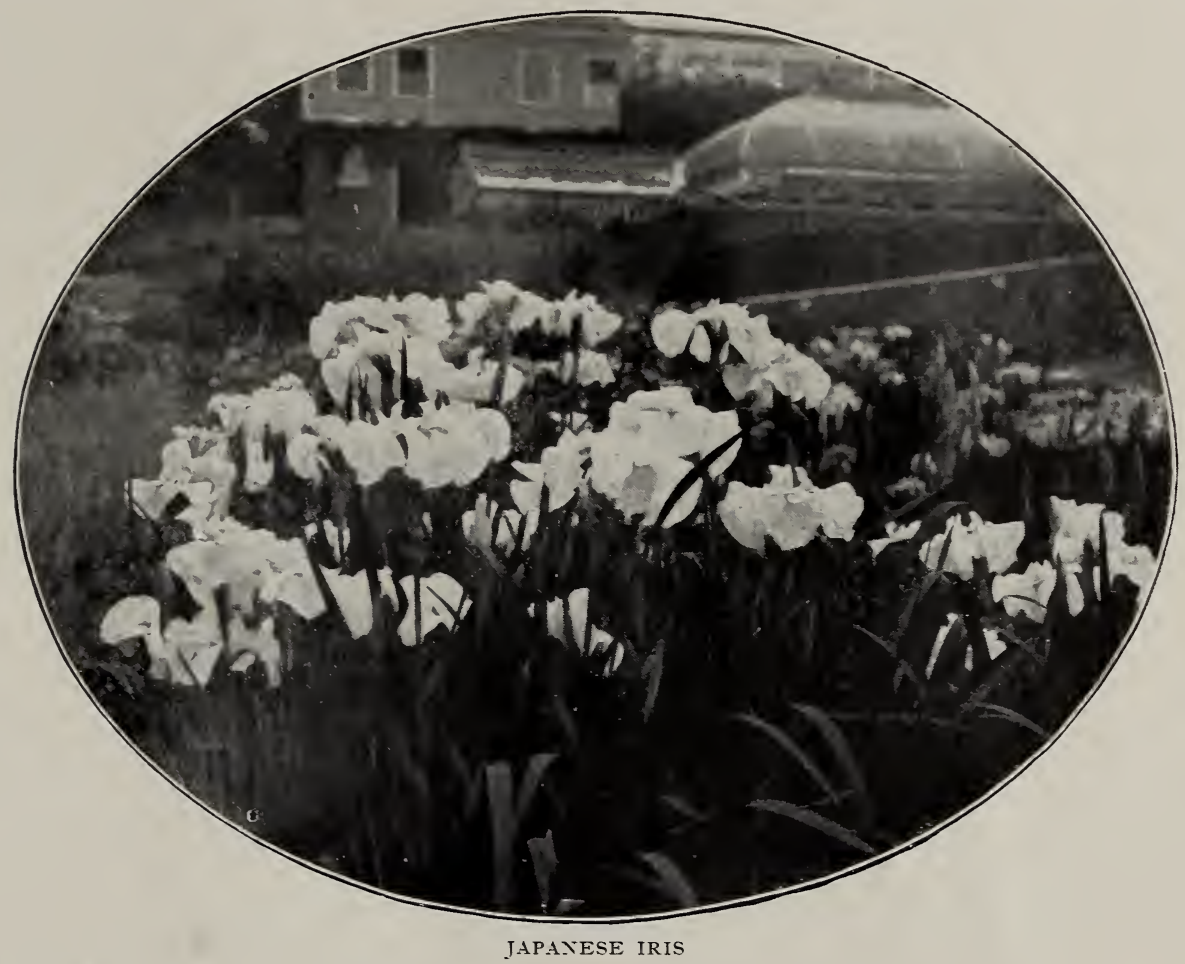

Hemerocallis Kwanso fl. pl. A rery free-flowering variety with double flowers of rich copper color: $t \mathrm{ft}$. Thunbergii. Lemon-yellow, flowering in July and August; 2 to 3 feet.

HERNIARIA glabra. Turk's Herb. A closely tufted moss-like plant with small greenish flowers, the foliage turning to deep red in winter: fine for the rockery.

HEUCHERA sanguinea. Alum Root. Handsome, dwarf, bushy plants of robust growth and easy culture: excellent for edge of bed or for rockery, as the foliage grows only 6 to 8 inches high and sends out beautiful spikes of coral-red flowers in great profusion during July and August; I to 2 feet high.

HIBISCUS. Rose Nallow. A valuable border plant. having handsome bright leaves and large showy blossoms.

albus. Crimson Eye. Large, showy white flowers; crimson eve. 4 to 5 feet. Blooms in August.

Moscheutos. Purplish red to nearly white, with darker eye: 5 feet; July to September.

roseus. Large, showy rose flowers. + to 5 feet.

HOLLYHOCK (Althae rosea). One of the noblest of hardy plants. It is well fitted to break up ugly. lines of shrubs or walls by its tall, stately growth. Deep cultivation, much manure and frequent watering in dry weather will secure fine spikes of flowers; flowers form rosettes of lovely shades of vellow, crimson, rose, pink, orange and white.

Allegheny Fringed. Semi-double, graceful and beautifully fringed at the edge of the petals ; 5 to 6 inches in diameter.

Old-fashioned Single. The old-time favorites in clioice mixture.

HOUSTONIA serpyllifolia. Bluets, or Quaker Lady. Low creepers, suitable for rockery in moist situation. They form broad carpets of foliage, almost hidden in spring by a cloud of showy light blue flowers.

HYPERICUM Moseranium. St. John's Wort. A beautiful, somewhat shrubby plant: dwarf habit: free and graceful: blooms in profusion in summer: flowers measure 2 to $2^{1 / 2}$ inches in diameter. A rich golden rellow:
IBERIS. Hardy Candytuft. A very desirable, lowgrowing evergreen plant for edging borders and for the rockery.

corraefolia. Compact heads of pure white flowers, about 9 inches high: MIay and June.

sempervirens. Evergreen Candytuft. Produces innumerable flat heads of pure white flowers during April and IIav.

sempervirens fl. pl. A pretty double form of the above.

\section{IRIS (Fleur-de-lis)}

These beautiful orchid-like flowers are divided into wo groups--bulbous and tuberous.

The bulbous kinds succeed in almost any light garden soil, but prefer sand, not too poor, but enriched with leaf-mold and rotten manure. They must have sun They need dry soil in winter to preserve the bulbs. The Spanish and English varieties are inexpensive and should be planted by the thousand. Left in same situation from year to year, they multiply with the least of care.

The tuberous kinds are fond of rich soil, abundance of moisture in summer, comparatively dry in winter. The most rigorous kinds are suitable for planting among large shrubs. Another good way is to place them here and there in carpets of low evergreens. Tufts of the finest kinds look very beautiful here and there among dwarf roses.

\section{SPANISH IRIS (Xiphoides)}

These choice early Irises give more flowers for the money than any other Iris. By covering the bed with glass in the beginning of April the flowers may be cut in War. Without glass ther bloom in early June. Plant only in autumn.

\section{ENGLISH IRIS (Anglica)}

For autumn planting. These beautiful flowers are second only to the Japancse in beautr; and some think ther are even more graceful, not being so heary. The markings are exquisite. They come into bloom after the German Iris and before the Japanese. 


\section{NEW HYBRID ALPINE IRIS}

These are perfectly hardy and useful for border or for forcing.

Charmer. Light cream-color.

Hayden. White, suffused with light blue.

Josephine. Pure white.

Meteor. Rich reddish purple with yellow beard.

Milton. Rich yellow, lined maroon; orange beard.

Stewart. Pure yellow.

\section{JAPANESE IRIS (Kaempferi)}

Flowers 9 to 12 inches in diameter; will grow in almost any soil that does not become too dry in summer. Prefer a warm sunny location, especially near water. As the Japanese names are unpronounceable, we give them by number. This set of varieties was selected from a large number of the best Japanese introductions and are, without doubt, as fine as any collection offered.

No. 31. Dense, pure white, yellowish blotches, petaloid stigmas; six petals.

No. 37. Ruddy crimson, primrose blotches with white halo; petaloid stigmas white tipped with purple; six petals.

No. 41. Lavender-blue with a blue halo surrounding the blotches and radiating out into feathers; petaloid stigmas red-lavender; a distinct and beautiful flower; six petals.

No. 43. Purple, overlaid with navy-blue, two standards; petaloid stigmas purple and blue; large orange blotches; six petals.

No. 47. Violet, double; several blooming close together at one time; six petals.

No.53. Clear white with large radiating yellow blotches; creamy standards; six petals.

No. 56. Blue with purple, heavily feathered white yellow blotches; standards blue, edged white; petaloid stigmas white, tipped blue; large flower; three petals.

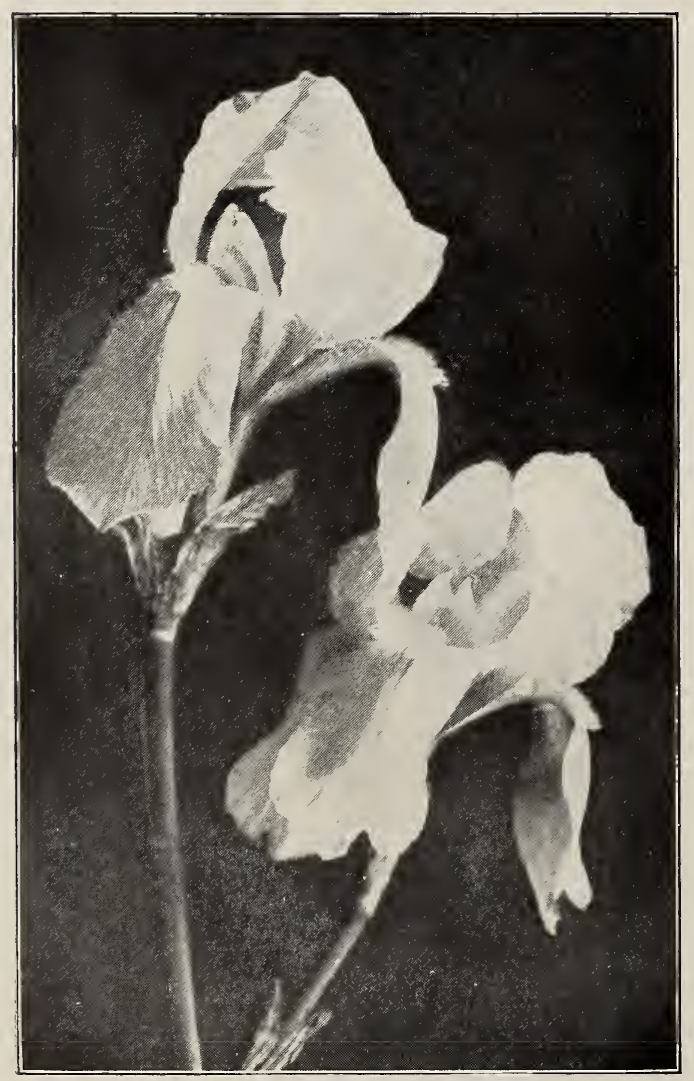

GERMAN IRIS, SILVER KING
No. 59. Intense tyrian blue; yellow blotches radiating into white; petaloid stigmas dark violet; six petals.

No.61. Sky-blue, veined white.

No. 63. Best double white; very tall.

No. 64. Deep blue.

No. 67. Deep lilac-purpie.

No. 71. Light violet-blue, slightly veined white.

No. 75. Deep crimson amaranth; yellow center.

No. 89. French white; extra large.

No. 91. Porcelain blue, veined; extra fine.

No. 15. Very early, pure white; three petals.

No. 4. The finest white; 6 petals.

No. 5. Six large petals; light violet purple, with few white veins.

No. 11. Three large petals; violet-purple, reined

No. 14. White ground, densely veined and mottled dark violet-purple; three large petals.

No. 16. Silvery white, suffused throughout with soft light blue; three extra large petals.

No. 26. Six large petals; deep purplish mauve, with yellow rayed center.

No. 29. Silvery white, densely veined and dotted with violet-blue; six large petals.

No. 43. Three white petals, deeply veined and suffused with violet-blue.

No. 57. Six petals; silvery gray, suffused and veined with violet-purple.

No.62. Three petals; white, mottled with violetpurple.

No. 65. Six petals, deep purple with yellow center; very effective.

No. 72 . Six round petals; bright violet-purple, shaded with blue.

No. 73. Three petals; white, delicately suffused with light parma-violet.

No.74. Six large white petals, densely marbled; spotted with bright violet-blue.

No. 78. Six large petals; bright violet, with a broad border of pure white in each petal.

No. 79. Three large petals; rose-tinted, white, reined violet-purple.

No. 80. Bright violet-purple veined with dark purple; three petals.

No. 83. Three large petals; a mottled violet-purple, shading to bright violet.

No. 87. Six petals; plumbago-blue, shading almost to pure white at center.

No. 91. Six petals; white, densely veined with rich violet-purple.

\section{GERMAN IRIS}

Apollon. Golden yellow, striped with plum color.

Atropurpurea. Purple; one of the best.

Augustina. Deep yellow, marked with maroon, giving a coppery hue.

Aurea. Clear golden yellow; fine

Bessie. Yellow and biown.

Bougere. Lilac and velvety purple; distinct.

Celeste. Delicate light lavender-blue.

Coelestine. Delicate lavender self.

Canary Bird. Lemon-yellow.

Common Purple. Purple; one of the best.

Delicate. Canary-yellow.

Deloismison. Lavender and purple.

Eugene Sue. Creamy white, with purple spots and stripes.

Falcata. Yellow, tinged with purple and purple stripes.

Flava. Pale yellow; fine.

Florentina. White, tinged with blue and yellow.

H. Cramer. Delicate pale blue.

Hector. Light bronze, stained with purple; fine.

Ignititia. White, suffused with purple.

Innocence. Lavender, fringed with white.

Jacquesiano. Deep maroon velvet, tinged with bronze and crimson; a rare and remarkable color.

Juliette. White, heavily veined with purple.

Lady Stump. Lavender and dark blue.

La Tendre. Lavender.

L'Avenir. Lavender; a beautiful shade.

Lemon. White, spotted with purple. and deep purple stripes: fine.

"A Woman's Hardy Garden." By Mrs. Elỵ. Sent free with a cash order of \$15 or more for perennials. 
Liabaud. Yellow and maroon; fine.

Louis Van Houtte. White, edged with blue.

Madame Chereau. White ground, fringed with blue. Ochroleuca. Golden yellow

Pancrea. Buff and purple; distinct; fine.

Pumila. Bluish purple; first to flower.

Reticulata superba. Centes lavender, outer purple; fine.

Sampson. Rich golden yellow; crimson-maroon, veined with white.

Sappho. Clear blue and indigo, beautifully blended. Silver King. Flowers silvery white; distinct and fine.

\section{CRIMEAN IRIS (Pumila Hybrids)}

A cross between the dwarf, early-flowering Ir is pumila and the large-flowering Iris Germanica. They grow about 6 inches high, and bloom a little later than Pumila, and have quite large flowers; exeellent for the hardy border or for early forcing.

Cyanea. Rich, royal purple, blackish shade.

Eburna. Pure white, creamy white shadings.

Florida. Beautiful lemon-yellow, shaded darker.

Formosa. Upper petals deep violet-blue, lower petals light violet.

\section{VARIOUS IRISES}

Cristata. Crested. Very fine species with small, orchid-like flowers; beautiful lavender; six inches high.

Pseudacorus. Common Water Flag. Whoever has in his garden a pond, ditch, or even a thoroughly damp spot, ought to plant this Flag; 2 to 3 feet.

Sibirica. Siberian Flag. Slender plant 2 to 3 feet high, with narrow grassy leaves; showy blue flowers, beautifully veined with white and violet.

LATHYRUS. Perennial Pea. Very desirable climbers producing a profusion of flowers during the summer; should be trained on a trellis.

grandiflorus. Everblooming Pea. Clusters of rosecolored flowers valuable for cutting; 3 to 4 feet.

LAVENDER vera. Well-known herb. Grows about I 8 inches high; flowers blue and very fragrant. July and August. I5 cts. each, \$r.5O per doz.

LIATRUS. Showy plants, with long spikes of purple and pink flowers. 15 cts. each, \$1.50 per doz.

pycnostachya. Kansas Gay-Feather. This most attractive plant blooms in midsummer; 3 to 4 feet high; rich, purple flowers which last for a leng time.

spicata. Large purple spikes; very compact.

Blanche Noba. Clear lilac; I foot. July and August.

LILIES. See page 26 .

LITHOSPERMUM coelestinum. An excellent lowgrowing plant for the rockery, with blue flowers; June.

LOBELIA cardinalis. Cardinal-Flower. Grown in an ordinary border this plant has a stunted appearance, but in a good soil, well supplied with moisture, the effect is grand; the most vivid scarlet flowers are borne in great profusion and last a long time; August to September.

LUPINUS polyphyllus. An effective plant producing large spikes of blue flowers. This is a fine plant for naturalizing, as it holds its own against stout weeds; 2 to 3 feet; June to September.

LYCHNIS alpina. Campion, Lamp-Flower. A diminutive form of L.Viscaria, the tufts seldom being more than a few inches high; grown without difficulty in the rock-garden or in rather moist, sandy soil; May and June.

Chalcedonica. A very desirable plant, bearing brilliant, orange-scarlet flowers; 2 to 3 feet high ; blooms all summer.

Chalcedonica fl. pl. Double-flowering form producing vermilion-scarlet flowers, exceeding the brilliancy of the brightest geraniums; July to September.

semperflorens plenissima. This pretty variety flowers throughout the entire summer. Color beautiful tender rose, and is produced in bushy spikes 12 inches long.
Lynchnis viscaria splendens fl. pl. German Catchfly. Forms a dense tuft of evergreen foliage surmounted by double, deep red, fragrant flowers, remaining in perfection for six weeks, during May and June.

LYSIMACHIA clethroides. Loosestrife. Japanese species. Long dense spikes of starry white flowers ; about 2 feet high. July to September.

nummularia. Money-wort. This is the most famil iar example of Loosestrife. No flower is more suitable for any position where long, drooping, flowerladen shoots are desired, whether on points of the rock-garden, in rustic vases or on steep banks; grows in any soil. Yellow bell-shaped flowers in June.

LYTHRUM roseum superbum. Rose Loosestrife A strong-growing, shrub-like plant 3 to 4 feet tall blooms from July to September. Flowers in large spikes of clear rose.

MERTENSIA Virginica. Virginia Cowslip, Bluebells. Formerly known as Pulmonaria. One of the most beautiful plants, both in foliage and in panicles of blue flowers borne early in spring in drooping clusters; stems $\mathrm{I}$ to $\mathrm{I} / 2$ feet high. Delights in moist, peaty, sheltered nooks. Charming old garden plant.

MONARDA. Bee balm. Showy flowers of the simplest culture, thriving everywhere. Excellent for naturalizing in woods and shrubberies.

didyma. Oswego Tea. Robust, about 3 feet high ; flowers bright scarlet, continuing in bloom a long in summer.

MORINA longifolia. Whorl-Flower. A handsome and singular perennial with large, spiny leaves, resembling those of certain thistles. Grows 2 to 3 feet high in ordinary soil, bearing robust spikes of rose and white flowers in whorls from June to Aug.

MYOSOTIS. Beautiful alpine plants, charming in all ways for rock-gardens.

alpestris. A compact plant forming a cushion of the loveliest blue flowers, thriving in moist, gritty soil.

palustris. A variety that is hardly ever out of flower; useful for a shady spot in the border; should be grown in partial shade or as a carpet to taller subjects, in moist, well-drained soil.

MONTBRETIAS. See page 27 .

OENOTHERA. Evening Primrose. These are among the most beautiful and attractive of hardy plants and are easily grown in all soils. Flowers are large, showy and pleasingly fragrant; from June onward they are in their beauty. Flowers large, bright yellow or white. The taller varieties are suitable for the wild gardens and shrubbery.

glauca Fraseri. Beautiful rich yellow flowers from June to September. 18 inches.

Missouriensis. Prostrate downy stems and clear yellow flowers, 5 inches in diameter, borne so freely that they may be said to cover the ground with gold. Especially valuable for rock-garden; delights in warm, light soil.

speciosa. The plant is erect, I4 to 18 inches high; large flowers, first white and changing to light rose; especially valuable for borders or the rougher part of the rock-garden.

OMPHALODES. Navelwort. Pretty dwarf rock plants. Very useful for the flower-garden.

verna. Creeping Forget-me-not. No plant is more worthy of naturalization; in cool, thin woods it runs about like a native plant, and in any position is one of the prettiest plants. Flowers deep, clear blue with white throats. July and August.

PAPAVER alpinum. Alpine Poppy. This has beautiful yellow flowers with white centers; similar to Iceland Poppy, but smaller in all its parts.

nudicaule. Iceland Poppy. Handsome for the rockgarden forming rich masses of cup-like flowers of rich yellow color; $x 2$ to $x 5$ inches high. Should be treated as an annual. Blooms from June to Oct.

orientale. Oriental Poppy. This is the most showy and noblest of all the Poppies. Effective for borders or in the shrubbery. Scarlet flowers, 6 inches in diameter borne on stems 3 feet high. 


\section{PEONIES}

No flower exceeds the Peonies in popularity, and none is more easily grown. They are not attacked by insects or diseases, and are perfectly hardy, requiring no covering in the severest weather. They thrive in all kinds of soil and flourish in a rich, deep loam. They demand much moisture at blooming time, and if grown in partial shade the blooms will, therefore, last longer and be equally fine in other respects. Plant eyes 2 inches below the surface and pack the earth firmly about the roots.

Although they may be planted in spring or late fall, best results are obtained if planted in September, as the plant becomes sufficiently established to mature the bloom the following June

\section{SINGLE JAPANESE}

They measure 6 to 7 inches across. Twelve varieties of the very finest in cultivation, including all the delicate shades from pure white to purple.

\section{DOUBLE CHINESE}

Hardy as an oak, thriving in any rich soil and with the least possible care. The choice double varieties named below should be in every garden. Heavy clumps which will bloom the first season.

\section{PAEONIA OFFICINALIS}

Alba plena. Double white, tinged red.

Rosea. Double crimson, changing to rose; fragrant. Rosea superba. Shining satiny rose; magnificent flower.

Rubra. Double crimson, of large size; fragrant; the old-fashioned red Peony.

Tenuifolia. Single, dark crimson; very rich fern-like foliage, flowers distinct; earliest flowering.

Tenuifolia fl. pl. Double, fennel-leaved; flowers of a bright scarlet-crimson, and quite double and globular; rare and fine.

\section{CHINESE PEONIES}

Ambroise Verschaffelt. Purplish crimson; very full, fragrant ; one of the finest.

Auguste Lemonnier. Velvety red; large, full and beautiful.

Atrosanguinea ( $\mathrm{C}$ a lot). Deep bloodred; metallic luster; early

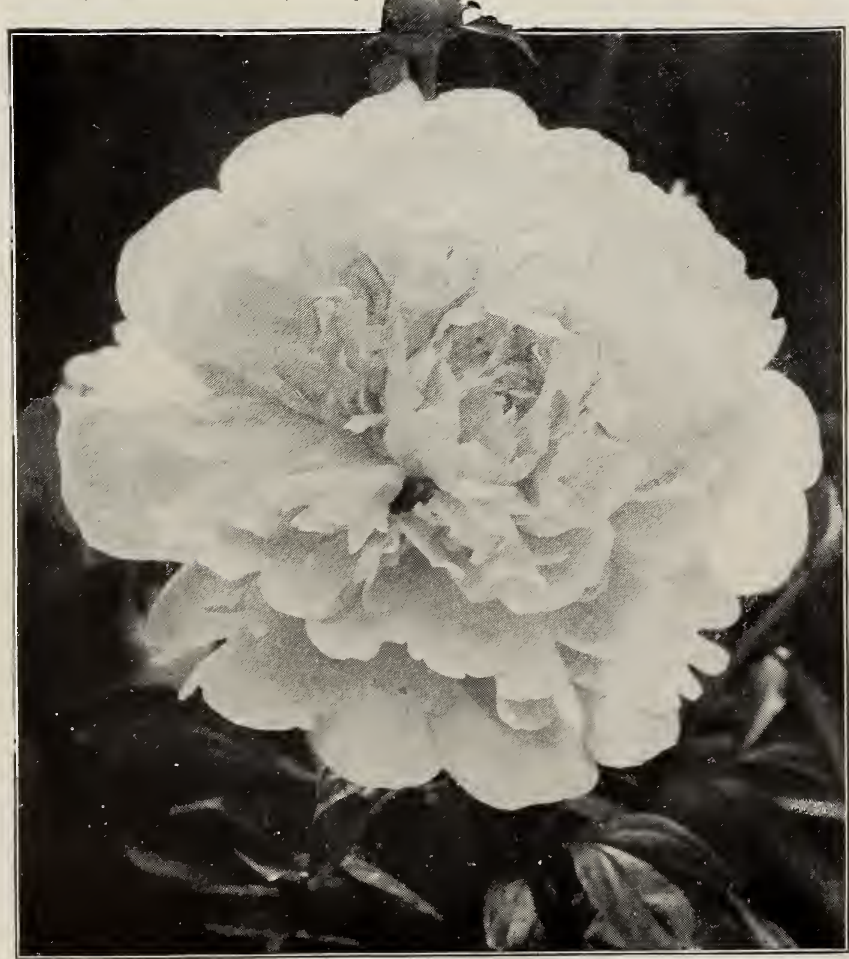

FESTIVA MAXIMA PEONY
Artemise. Rose of several tints; good form.

Berlioz. Late; large, full, globular; bright currant-red.

Carnea elegans (Guerin). Rose, one shade ; splendid shape.

Charles Binder。Violet-red; fragrant; good.

Charles Gosselin. Salmon-color, center light yellow.

Charles Verdier. Light lilac-rose; very large and of perfect form; a superb variety; late.

Charlemagne. Enormous flowers, very double, imbricated; flesh white, center tinted lilac and chamois; very fine.

Couronne d'Or. White, with yellow reflection, center petals bordered with red; extra.

Daniel d'Albert. Deep rose, shaded purple; large, globular flower.

Delicatissima. Delicate fine rose; very large, full and sweet.

De Candolle. Currant-red, tinged amaranth, distinct color; best of its shade; very large and double; fine.

Delachii. Dark purplish crimson, shaded violet; fine.

Dr. Bretonneau. Rosy violet; very large and fine; fragrant.

Duchesse de Nemours (Calot). Sulphur-white; fragrant; good shape; extra.

Duke of Wellington. Large, well-formed, sulphurwhite bloom; habit ideal; stems very firm and long; strong grower, very fragrant.

Edulis, or Fragrans. Violet-rose, all of one color; very full and sweet.

Felix Crousse. Bright red, distinct color; fine bomb shape; large and massive; no stamens.

Festiva. Pure white, with a few marks of carmine in the center.

Festiva maxima. Resembles the preceding, but flowers are much larger and in clusters; fragrant.

Fulgida. Crimson; profuse flowering; extra fine.

Golden Harvest. Very striking variety, producing large, tri-colored blooms, the guard petals being blush pink with a distinct blush white collar and blush center; a few of the center petals tipped and striped light crimson, the general effect of the flower being creamy pink ; delicate fragrance.

Grandiflora carnea plena. Very large; outside petals delicate blush; center fringed, yellowish; sweet and fine.

Henri Demay (Calot). Violet-purple; very large and full: fragrant; late; fine.

Humei. Purplish rose; very full and double; very large and showy, and one of the latest in bloom. As much as three weeks later than the earliest of the Peonies.

Insignis. Carmine-rose ; fine form, fragrant, good.

Jeanne d'Arc. Outside petals rosecolored, inside straw-colored, with crimson spots.

Jussieu. Deep black-purple; good.

Latipetala. Outside petals flesh-color, center ones yellowish white. Very large and fine.

La Tulipe. White, center rose; exterior bright carmine, center dark carmine striped; beautiful in bud and bloom.

Louis Van Houtte. Dark crimson; very compact, fragrant and late.

Louis Van Houtte (Calot). Bright purple-cherry; large, globular and full; fragrant; superb. 


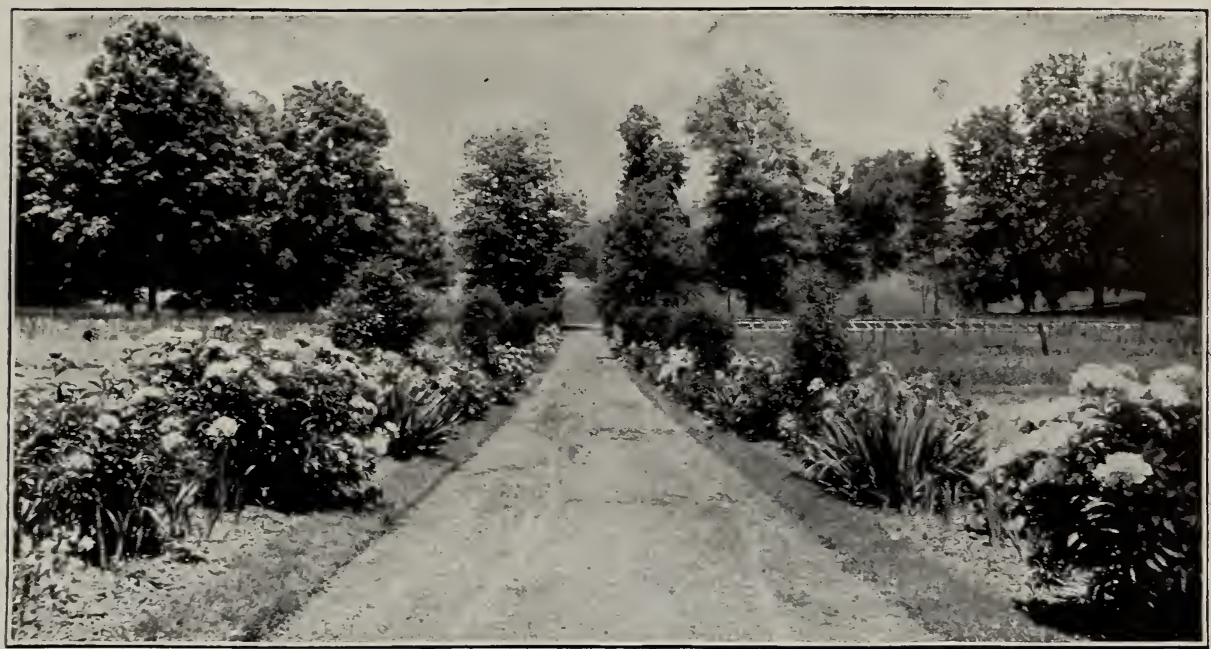

CENTER PATH IN THE GARDEN OF WM. ROCKEFELLER, TARRYTOWN, N. Y., SHOWING IRIS AND PEONIES

CHINESE PEONIES, continued

La Rosiere. Large flower; double, well-shaped; globular. Petals broad; center pale yellow, yellowish white border. This variety resembles a tea rose.

Madame deVerneville. Enormous well-shaped flower pure white; first-class variety, delightfully fragrant. Madame Crousse. White, tinted pink, center carmine bordered; very fragrant.

Mr. Krelage (Crousse). Deep rose-red, very fine shade; very full and free, and a fine variety.

Monsieur Dupont. White, tinged yellow, carmine bordered: late.

Madame Geissler. Silvery rose, shaded crimson; very large and full; fine form; one of the best.

Madame Lebon. Very large; bright cherry, some petals white; fragrant, good.

Marie Lemoine. Large; flesh white; fine dwarf habit; a fine sort.

Madame Victor Verdier. Crimson-rose, with light riolet; very large and full; late.

Modeste (Guerin). Deep rose; bright and showy; very large, distinct and fine-shaped; fragrant; superb variety.

Monsieur Boucharlat. Bright rosy lilac; large and full flower, imbricated like a rose; very late; fragrant.

Mont Blanc (Syns., Sulphuria, Solfaterre). Fine, large, early, fragrant; white, with lemon center, giving the general appearance of a light sulphuryellow; habit strong and vigorous; fragrance pronounced; excellent shipper.

Prince de Talindyke. Dark purple: large, distinct.

Purpurea superba. Purplish crimson, good shade; large and showy.

Papilionacea. Outside petals rose, center ones yellow, changing to white.

Rubra triumphans. Dark purplish crimson; petals large; very sweet; semi-double.

Rubra superba (Richardson's.) Dark purplish crimson ; petals large ; semidouble; very sweet.

Solfaterre. Sulphur-yellow; an extra good sort. See MIont Blanc.

Triomphe de l'Exposition de Lille. Delicate rose; dwarf habit ; fine.

Triomphe du Nord. Violet-rose, shaded with lilac; a fine color; beautiful.

Viscomtesse Belleval. Blush, center creamy white; beautifully fringed; fragrant.

Violacea. Deep purple-violet; very large and full.

Ville de Nancy. Deep brilliant crimson; late.

Mixed. Excellent sorts which cannot be positively identified as named varieties.
PENTSTEMON. Beard-Tongue. Most desirable perennials for either border or rockery. They like a friable loam with a mixture of well-decayed leafmold and sharp sand.

Barbatus Torreyi. Spikes of brilliant scarlet; very effective; height 3 to 4 feet; June to August. Digitalis. Large spikes of long, pure white flowers with purple throats; July and August.

pubescens. Pure rosy purple; $\mathrm{I} 1 / 2$ feet; July and August.

\section{HARDY PERENNIAL PHLOXES}

The author of "A Woman's Hardy Garden" says "There is no flower more beautiful, more easily cultivated, or giving so much bloom as the Phlox. I certainly could never have a garden without it." Like other perennials, the new varieties are most beautiful. After weeding out the dull reds, purple, magenta, etc., we offer only those rich colors that should be in every garden. Set in the fall, Phloxes bloom more abundantly than in spring. Plant in September and early October for best results. Plant also in April.

Amazon. Large flower; pure white. Fine.

Belvidere. Salmon-pink. A choice sort.

Bridesmaid. White, with large crimson center.

Beranger. White, suffused with pink; rosy lilac eye.

Caran d'Ache. Bright carmine-rose; distinct.

Coquelicot. Fine, rich scarlet, with deep carmine eye.

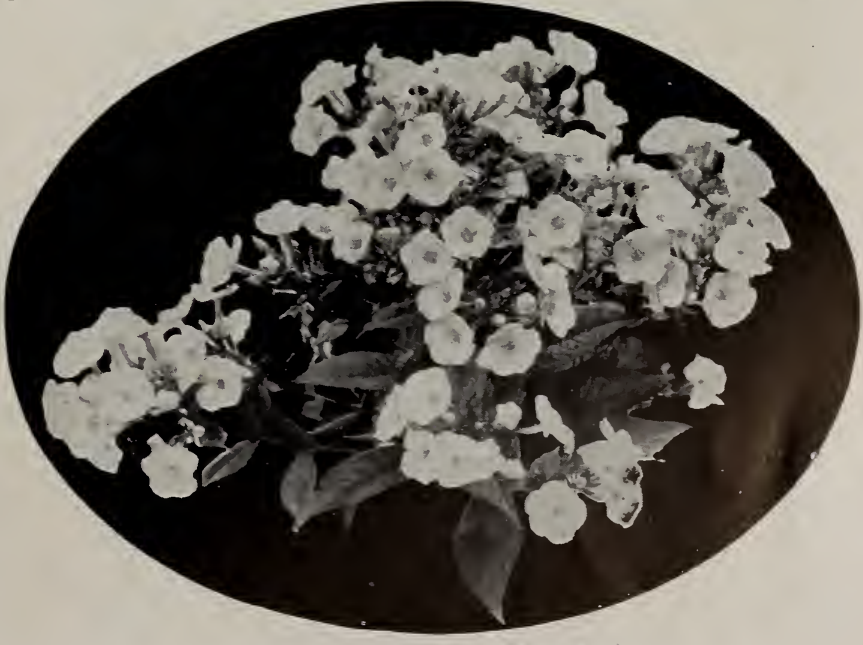

PHLOX, LA VAGUE (See page 24 ) 
HARDY PERENNIAL PHLOXES, continued

Cross of Honor. Each petal lilac color, with a white margin; beautifu1.

Flambeau. Large flower; bright orange-red, dark center; fine.

Henry Murger. White, with carmine eye; the best of its color.

La Vague. Large; rosy pink, with red eye; choice.

Lothair. Large; rosy salmon, with crimson eye.

Matador. Large flower; bright orange-red. Distinct and fine.

Professor Schlieman. Salmon-rose, with carmine

eye.

Pantheon. Deep salmon-rose; very fine.

Peachblow. Delicate pink, with white markings.

Pearl. Pure white.

Purity. Snow-white.

Queen. Pure white.

Pecheur d'Islande. Soft salmon-scarlet with a white center.

R. P. Struthers. Bright rosy red; crimson eve.

Sunshine. Deep salmon-pink; dark eye.

William Robinson. Flowers very large; pale salmon, with rose center. Fine.

Miss Lingard. We offer a fine stock of this new, everblooming variety. This Phlox blooms in May, fully six weeks earlier than the other sorts, and continues in bloom three months; a grand white variety, which should be in every collection; is not so tall a grower as Queen. Although the demand for this variety excels that of all other whites, we have put the price very low. Height 2 to 3 feet.

Phlox subulata (Moss Pink). Rose-pink. subulata alba. White.

PHYSOSTEGIA. False Dragon-Head. Handsome perennials forming dense bushes 3 to 4 feet high, bearing long spikes of delicate tubular flowers.

Virginica. Soft pink.

PINKS. See Dianthus.

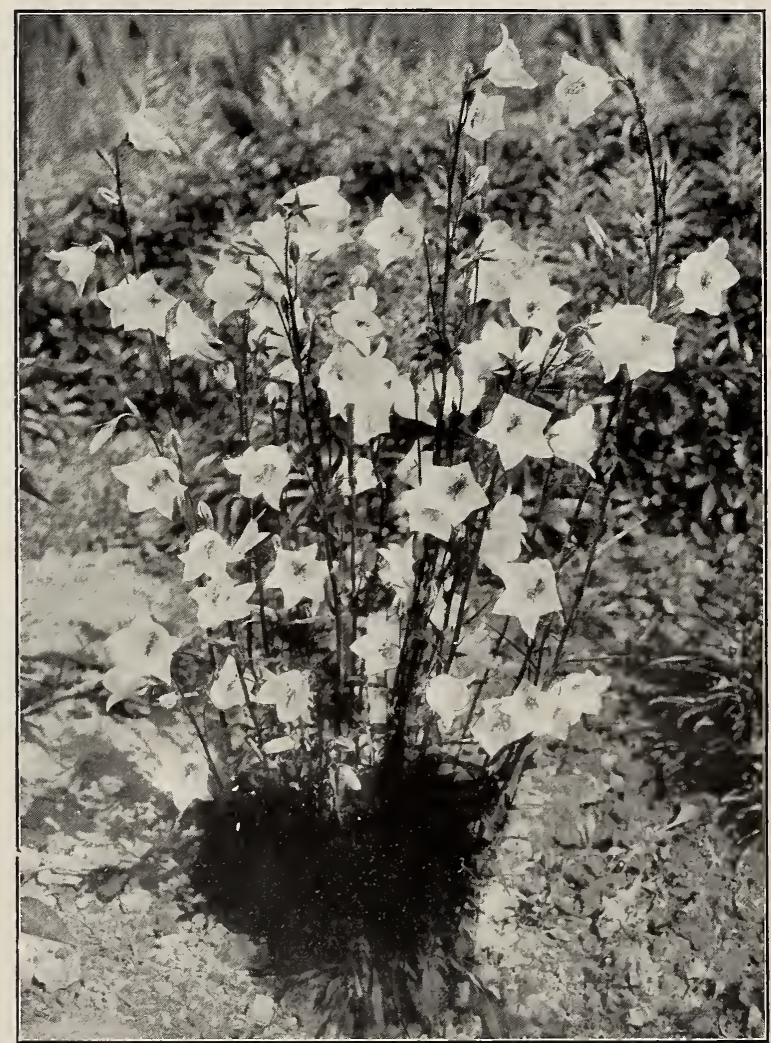

PLATYCODON GRANDIFLORUMI
PLATyCODON. The Balloon Flower. Closely allied to the Campanulas, bearing a succession of flowers from June until October.

grandiflorum. Deep blue-cupped, star-shaped flow ers; I $1 / 2$ Io 2 feet.

grandiflorum album. A white-flowered form of the above.

Mariesa. Deep blue, bell-shaped flowers, nearly 3 inches across, on plants I foot high.

POLEMONI U M caeruleum. Jacob's Ladder. Thrives best in a deep, rich but well-drained loam; fine for rock-garden or border. Pretty tufted foliage surmounted by spikes of deep blue flowers in June.

POLYGONATUM majus. Solomon's Seal. One of our most beautiful plants in foliage and flower, bearing pendent creamy white flowers from the axils of the leaves.

PRIMULA. Primrose (see also CEnothera). Some of the Primulas are at home in the sunny slope of the rock-garden-others in shade, many make excellent border flowers.

cortusoides Sieboldi. Japanese Primrose. Very vigorous growth and dark green foliage; throw up in the spring innumerable stems of large flowers; excellent for the rock-garden; should be planted in well drained soil or in raised positions in the rock-garden.

rosea grandiflora. One of the finest Primroses in cultivation. Very free-flowering; clear rose-color: Its flower stems, 4 to 9 inches high, are produced in early spring. Prefers a deep rich loam in the moist, shady part of the rock-garden.

veris superba. Giant form of the English Cowslip, producing individual flowers from $I$ to 2 inches across. Color canary-yellow with golden center.

vulgaris. English Primrose. An old favorite; a plant that should be found in every garden. One of the earliest flowers to open; bright canary-yellow and very fragrant.

PULMONARIA saccharata masculata. Lung-wort. Of easy culture and rivaling the choicest hothouse plants in the marking of its foliage. This little plant, growing one foot high, is very attractive at all times, and especially in May and June with its spikes of light pink flowers changing to blue.

PYRETHRUM. Flowers in June similar to those of the asters, ranging in color from the purest white to crimson. Excellent for cut-flowers.

Alfred Kelway. A fine crimson with lighter center.

Meteor. Deep rose-pink with white lips.

uliginosum. Giant Daisy. Grows 4 to 5 feet high and is covered with large white daisylike flowers 3 inches in diameter. July to September.

RUDBECKIA. Cone-Flower. This is the genus to which the Golden Glow belongs-a plant that has been very popular. Equally good is the species Newmanii, with flowers of a rich orange-yellow, with velvety maroon center. They are from 3 to 4 inches in diameter and borne in dense masses from July to late October. The plant is more compact than Golden Glow, growing only 2 to $2 \frac{1}{2}$ feet high.

Golden Glow. Heavy clumps.

Newmanii.

purpurea. Giant Purple Cone-Flower. Entirely distinct from all other perennials in formation and color of the flowers. They are peculiar reddish purple, 4 inches in diameter, with a brown cone-shaped center. 3 feet high; blooms from July to October.

SANGUINARIA. Bloodroot. Desirable native plant blooming in May. Flowers pure white; 6 inches.

SANTOLINA incana. Lavender Cotton. A dwarf plant of neat habit and having hoary foliage, useful for edgings and in the rockgarden. It is half-shrubby and holds its leaves through the winter. 
SAPONARIA ocymoides. Rock Soapwort. An elegant perennial trailer producing, during the summer months, masses of small, bright rose flowers.

SAXIFRAGA. Rockfoil. The Rockfoils thrive in any kind of soil. Being a foot high or less, they are desirable for the front of the border or for the rockgarden. They form masses of handsome broad, deep green foliage, and bloom very early in spring. cordifolia purpurea. This Siberian plant differs in aspect from the ordinary dwarf Rockfoils. May be used with good effect near cascades and on the rocky margin of streams. Fine foliaged plants of the rocks; height I foot. Rich purple flowers in April.

Himalaica. Rose-color; 2 inches.

ligulata. White flowers; anthers deep crimson. Should be given a sheltered situation and also a little shade.

SCABIOSA Caucasica. Pin-cushion Flower. A handsome hardy plant with flowers of beautiful soft lilac color. Fine for cutting; last a long time in water.

SCUTELLARIA alpina. Helmet-Flower, or Skullcap. A pretty trailing plant for the border or rockery. Flowers purple with yellow lip; August and September.

SEDUM. Stonecrop. Rock and alpine plants which thrive in nearly every soil. They are beautiful in the border and of the easiest cultivation. S. acre, from its creeping foliage called Golden Moss, has bright yellow flowers. S. maximum atropurpu. reum grows from I to 2 feet high, and from the vivid purple stems and leaves makes a showy mass. S. spectabile is distinct and beautiful. Its rosy purple flowers, in dense, broad corymbs, appear in August and last two months. The glaucous foliage forms a pleasing contrast to any highly colored foliage that may stand near it.

SILENE acaulis. Catchfly. Cushion Pink, or Dwarf alpine ; in summer giving a mass of pink or rosecolored flowers. Abundant in the northern part of the British Isles. Succeeds in almost any spot in the rock-garden.

alpestris. Alpine Catchfly. Succeeds in any soil and is 4 to 6 inches high; its white flowers appear in May. Should be used abundantly in every rock garden.

Schafta. Charming border or rock plant 4 to 6 inches high, blooming from July to October; thrives in almost any position in the rock-garden.

SPIREA. See Astilbe.

STACHYS lanata. Woundwort. This beautiful woolly-leaved plant is useful for edging. It thrives in any soil and makes a beautiful contrast with other foliage. Flowers inconspicuous.

STATICE latifolia. Great Sea Lavender. A valuable plant for either rockery or border; foliage tough, leathery and covered with immense heads of small, deep blue flowers. I5 to I8 inches high. June to September.

STOKESIA cyanea. This is one of the best blue flowers, blooming from early July to late October. Flowers handsome lavender-blue, 3 to 4 inches in diameter; effective in masses or beds; it grows almost 20 inches high and is of easiest culture.

SWEET WILLIAM. See Dianthus.

THALICTRUM. Meadow Rue. The Meadow Rues have fine foliage, but not showy flowers. The fernlike foliage is very pretty mingled with flowers in bouquets; more lasting, however, than fern fronds. They all do well naturalized.

adiantifolium. Finely cut, maidenhair-like foliage and yellow flowers; 15 to 18 inches.

aquilegifolium atropurpureum. This beautiful fern-like plant grows 3 to 4 feet high, and thrives in any soil. Its dark, purplish stems and deeply cut leaves are very useful with vases of flowers.

minus. May be grown in any soil, but the slender flower stems which appear in May and June should be pinched off; well suited for mingling with flowers in vases; looks well in borders or in carpets of dwarf subjects.

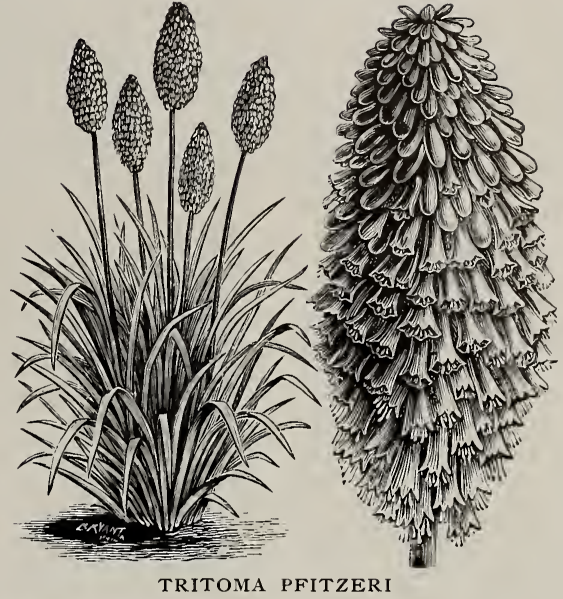

THYMUS. Thyme. Nothing can be more charming in sunny bank of rock-garden.

citriodorus aureus. Golden Thyme. A pretty, golden variegated variety; evergreen. Grows 9 inches high and is dense and compact.

lanuginosus. A trailing variety with white flowers and gray foliage. Thrives in any soil if exposed to the sun.

Serpyllum. Small, lilac-colored flowers in summer.

TRILLIUM erectum. Wake-Robin, or Wood-lily. A native early-flowering plant; color maroon; 6 to 9 inches ; in April.

grandiflorum. The finest of all the Trilliums. This is a free-growing plant suitable for a shady, peaty border, nooks in the rock garden or hardy fernery. 5 to 12 inches high; April.

TRITOMA Pfitzeri. Torch Lily. For color effect in orange-scarlet nothing equals this free-flowering, easily-grown plant. The spikes are 3 to 4 feet high, and heads of bloom Io to 12 inches long. July to September.

TROLLIUS. Globe-Flower. No garden plants are more desired than Globe-Flowers. Habit compact, and in both foliage and flowers are beautiful; flowers vary from a pale yellow to a deep gold; bloom in spring or summer. May be grown in beds or naturalized by ponds, streams or wet places.

Caucasicus. A new variety with large orange-colored flowers.

Europaeus. A giant buttercup in appearance; very fine; flowers bright yellow, 2 inches in diameter on stalks 2 to $2 \frac{1}{2}$ feet high; May to August.

Japonicus. "Excelsior." Very deep orange flowers. VERONICA. Speedwell. The Speedwells are mostly natives of New Zealand, flowers being of a blue shade, varying to rose and dull white. They succeed in any garden soil in sunny situations. The low-growing forms are good rock plants.

alpina. Slender, delicate plant, bearing small blue or violet flowers; adapted to the rock-garden.

incana. A dwarf plant with silvery leaves; dark, rich purple flowers.

longifolia subsessilis. A pretty species with blue flowers produced on spikes I to I $1 / 2$ feet long, continuing in bloom the entire summer.

spicata. Fine border plant, about is inches high, producing spikes of bright blue flowers in summer.

VINCA caerulea minor. Myrtle, or Periwinkle. A blue-flowering, trailing evergreen. Excellent for carpeting the ground under trees where grass will not grow.

major variegata. Trailing habit; leaves variegated green and yellow; fine for graves and boxes.

VIOLA cornuta. Tufted Pansy. These plants are becoming general favorites. If planted in a partially shaded bed they will flower for nearly eight months of the year. While the flowers are not as large as those of the pansy, their bright colors will make them welcome additions to the garden. 
Viola, Admiration. Soft purple-lilac, with dark blotch.

lutea splendens. Rich, golden yellow.

Papilio. Violet-lilac, with a dark eye.

White Perfection. A fine white.

YUCCA filamentosa. Adam's Needle. This has no rival in its peculiar habit and style of growth. The

\section{Yucca filamentosa, continued}

effect of Yuccas is equal to that of any hothouse plant that may be planted in the open air for the summer, while they are green and ornamental at all seasons. The Yuccas are so vigorous that it is almost impossible to kill them. When first planted they die down to the ground, but if left alone they will renew their growth.

\section{LILIES}

"So extensive and beautiful is the genus Lilium, so varied in form, color and periods of blossoming, that, like the daffodil, a garden night be composed of it alone." Although there are a great many species, we cunfine ourselves to those of easy culture. Lilies like a rich, deep, well-drained but moist soil and partial shade. If planted in full exposure to the sun it is well to mulch around the roots. They should be planted deep, the top of the bulb at least six inches below the surface, using plenty of coarse sand about the bulb. After hard frosts set in, four or five inches of litter or leaves should be placed over them. Japanese Lilies are very effective among Rhododendrons and Azaleas, and flourish under the same culture. The best soil for growing in pots is leaf-mold and sand or other light, rich mixture. No manure should be used near the bulbs. Begin with the smallest sized pot, and shift to larger ones as the plants grow. Give cool temperature and liberal watering after growth begins.

\section{GARDEN LILIES}

For several years I have made a special bulb offer of these gorgeous flowers, and that my customers have been delighted with the results may be seen from the rapidly increasing sales. Other choice varieties with prices on application, together with books treating of their necessary culture. Buibs arrive late in autumn.

Candidum (Madonna, or St. Joseph's Lily). Coming into bloom with the roses and blue larkspur, what a pageant they form! This Lily is easy of culture, quick to increase, and thrives in almost any soil and position. Like other Lilies, they should not be disturbed. Plant in early September for best results.

Japanese Lilies may be planted in spring or fall with excellent results. They are especially appropriate for garden or border of old-fashioned flowers, including the Tiger Lily. The following varieties are choice and easy of culture: Auratum, Speciosum album, Speciosum rubrum, Speciosum Melpomene, Tigrinum splendens.

\section{HARDY FERNS}

But comparatively few of hundreds of Ferns known are sufficiently hardy to be planted in our northern climate. We have selected only such as are known to be perfectly hardy in northern New England. As a rule, they do well for shady locations and for filling in places where other things cannot be grown, but they must not be planted under trees, whose roots would rob them of all moisture. They need a good dark soil, such as leafmold and turf-loam mixed with sand, and where they can have plenty of moisture. Such a place may be prepared for them if the soil is not favorable. Where leaf-mold is not handy, well-decayed peat will take its place, or fine chip dirt well rotted. We have named some varieties, also, adapted to fairly dry positions. Let us know the positions in which you wish to plant and we will make up an appropriate assortment. The rockery is fine for Ferns.

Adiantum pedatum. Maidenhair. This well-known Fern makes a good plant when it can have sufficient moisture and drainage. Will grow either in shade or sun.

Dryopteris cristata. Commonly found around old stumps and decayed trees in open meadows and pastures. Delights in wet ground; one of the best.

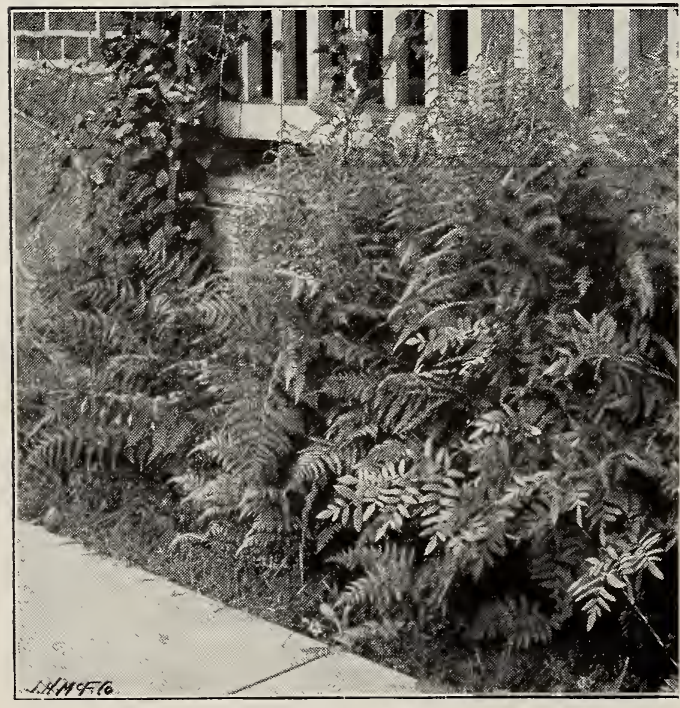

HARDY FERNS
Dryopteris marginalis. Marginal Fern. Very satisfactory in partially dry positions. Its light green fronds, which have a bluish tinge, are evergreen, and will last a long time as cut specimens; especially desirable for the rockery.

D. spinulosa. A beautiful evergreen variety of medium size and finely divided fronds. A fine plant for any corner; height about $\mathrm{I} / 2$ feet.

D. thelypteris. Lady Fern. Will thrive in either shade or full sunlight, if it have plenty of moisture. Fronds about 2 feet high, long and narrow.

Onoclea sensibilis. Sensitive Fern. Although easily grown in almost any location, it is not so popular as some of the others because of its coarse nature.

O. struthiopteris. Ostrich Fern. This is one of the largest of the handsome Ferns, growing 3 to 4 feet high, with handsome dark green fronds in vase form; likes plenty of moisture, and shade a part of the day.

Osmunda cinnamomea. Cinnamon Fern. This Fern derives its name from its cinnamon-colored fertile fronds. Thrives in wet soil, although it will do well in almost any location.

O. Claytonia. Interrupted Fern. Similar to the Cinnamon Fern except that some of the fronds are interrupted by being covered with spores. Not so partial to moisture as the above.

O. regalis. Royal Fern, or Buckhorn Brake. In favorable situations this Fern grows to a height of 5 or 6 feet; in the garden it will grow only about half that height. Delights in wet places; rather coarse, but especially appropriate in some locations.

Polystichum acrostichoides. Christmas Fern. This is the well-known, evergreen hardy Fern so easy to grow. It is used by the trade in bouquets; delights in rocky, half-shady hillsides; will do well anywhere.

Polypodium vulgare. Rock Polypod. Evergreen species covering rocks with a sheet of low-growing green, in locations not too dry and with little sun. 


\section{GLADIOLI}

Probably no summer-flowering bulbs are more attractive since the wonderful improvements in the size and coloring of Gladioli, and no flowers of equal value are so cheaply and easily produced, as they thrive in almost any soil and climate. By planting at intervals from April to June, flowers may be had in succession from July to September. Many of the flowers are 5 to 6 inches in diameter, and their exquisite coloring defies description. Cut the spike when the first flower opens, and the blooms will last nearly a week if the water in the vase is changed daily.

Plant in full exposure to the sun, in well-enriched garden soil, but use no manure near the bulbs. Where the soil is stiff clay, fill the trench with sandy loam. Plant a double row in the trench made the width of the spade and 4 to 5 inches deep. Deep planting has two advantages: the bulbs are not apt to suffer from drought, and soil above them forms a strong support to the stem, thus avoiding the necessity of staking. In double rows, also, one stalk acts as a support to another. Before the ground freezes in the fall, lift, dry and store the bulbs from frost as you would potatoes for spring planting.

\section{GRAND NAMED GLADIOLI}

America. A new variety now offered for the first time, having been thoroughly tested, and is conceded to be one of the finest varieties ever sent out; color a beautiful soft flesh-pink; growth and general habit perfect.

Augusta. A lovely white variety.

Brenchleyensis. The best scarlet; useful for color effect among other flowers or shrubs; whole spike of 15 to 25 florets open together.

Emma Thursby. The best variegated white ground, with deep rose marking and blotches through all the petals.

Eugene Scribe. Delicate rose, variegated with darker rose. One of the best.

George Paul. Enormous flowers of a rich rubygarnet shade.

Gil Blas. Immense orchid-like flowers of a rosy salmon cclor, with a fiery red blotch on straw-colored ground.

Giant Nanceanus. This grand race has flowers of immense size and transcendent beauty, rivaling the finest orchids.

Groff's Gold Medal and Silver Trophy Strain. This is a mixture of the cream of Groff's seedlings, all colors, including the new blue-lilac and heliotrope tints. Nothing better can be found than this.

Groff's Hybrids. No words can tell the beauty of Groff's Hybrid Gladioli.

Isaac Buchanan. A clear, rich yellow, slightly tinted on the lower petals.

Klondyke. Another new sort, offered for the first time, but by test proven highly satisfactory; color is a clear yellow, with a vivid crimson-maroon blotch in the throat; very free grower.

Lemoine's Butterfly Hybrids. Lemoine, of France, developed this grand strain, which held first place until the introduction of Groff's Hybrids in 1900 Some persons still think them equal to Groff's.

May. This very handsome Gladiolus should be more extensively planted. It makes beautiful spikes, compact and perfect. Its color is one of the most attractive, being almost a pure white with markings of bright rosy crimson. It is a strong, healthy grower and will give immense satisfaction in all localities for all purposes.

Mme. Monneret. A clear delicate rose; short spike; very fine late bloomer.

"1900." Fiery crimson flowers with prominent white blotch on each of the petals.

Princeps. This is one of the most vigorous and britliant of the new Gladioli. The color is rich crimson,

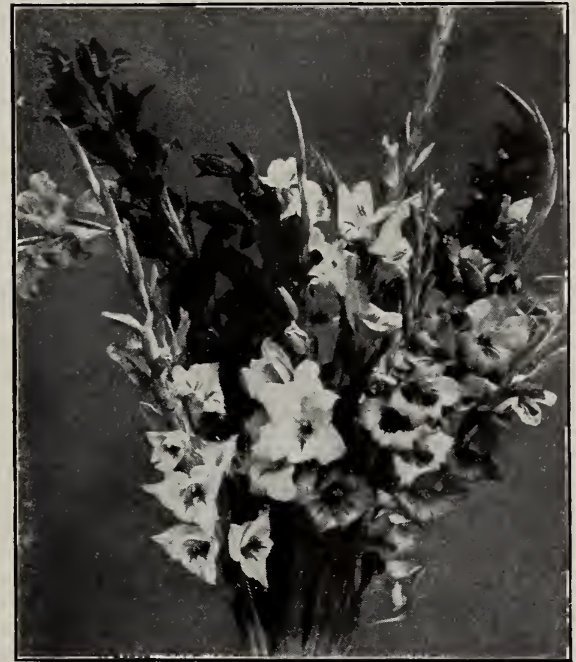

NEW HARDY GLADIOLI

with intense shadings in the throat and broad white blotches across the lower petals, which serve to intensify the brilliancy of the crimson. Flowers are 5 to 6 inches in diameter; petals are wide and much rounded, forming an almost circular flower.

Senator Volland. A most startling variety, with large flowers of pure blue, with dark blotch and yellow stain striped blue.

Ceres. Another highly valuable variety, one of the best of the white or light-colored ones; good free bloomer and fine grower; color white, flaked with purplish rose.

Shakespeare. Ivory-white, slightly suffused with carmine-rose, large rose blotch; early and constant.

White Lady. Most beautiful of all white Gladioli; extra strong grower.

William Falconer. A grand pink sort; immense flowers in spike.

\section{MIXTURES}

General Mixture, composed of all colors of good sorts, including many from the above.

Mixed Childsi

White and Light

Scarlet and Red Shades

Pink Shades
Orange and Yellow

Striped and Variegated

\section{MONTBRETIAS}

In growth the flowers resemble the gladioli, and produce spikes of brilliant flowers in shades of orange, yellow and red. The following varieties are all very fine :

Crocosmaeflora. Deep golden orange.

Etoile de Feu. Bright vermilion, yellow center. Gerbe d'Or. Splendid golden yellow.

Rayon d'Or. Yellow and brown.
Pottsii grandiflora. Golden orange, outside bright red.

Transcendent. Orange and vermilion.

Tigridia. Rich orange. 


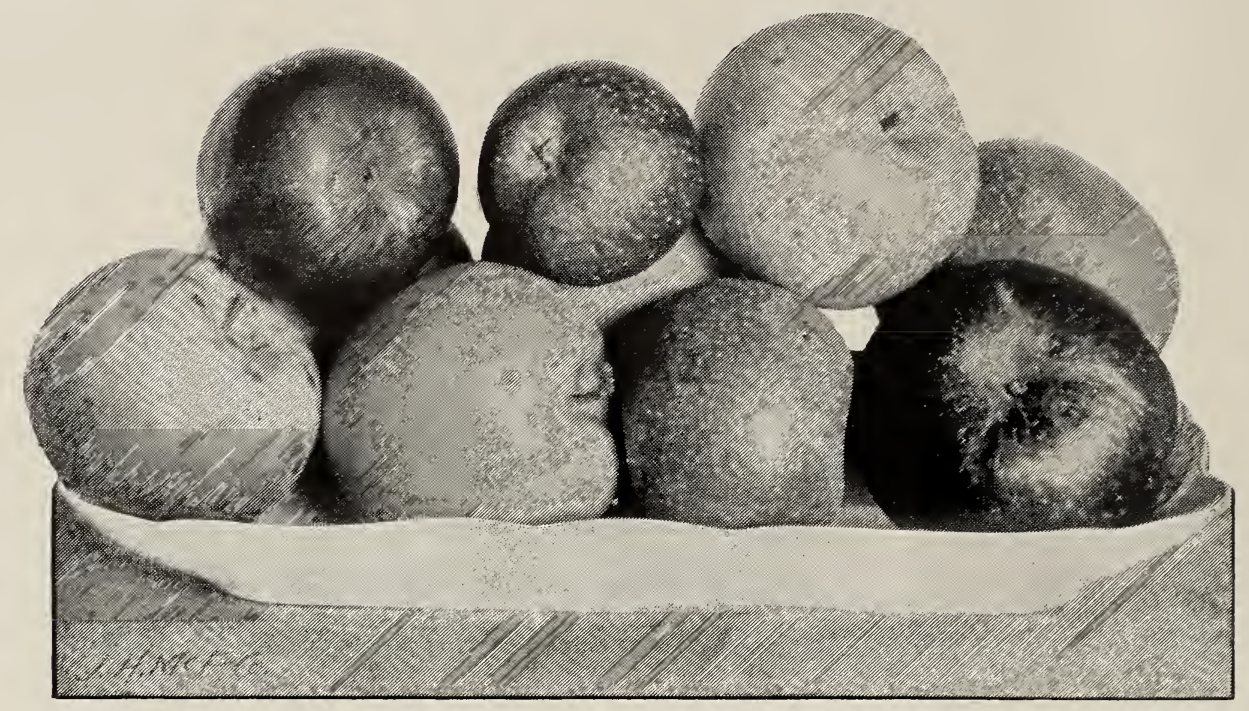

\section{New Fruits}

Two new berries have proven themselves so hardy, growing in the cold climate of the Berkshire Hills, at Lenox, Mass., and having so many other good qualities, that we procured the entire stock for introduction. Below is the description by Supt. Norman, of Erskine Park Estate.

Raspberry, Erskine Park Eberbearing. "This berry does not begin to fruit until the thed perhaps, when you were here it fruits on the narieties are through. As you no-

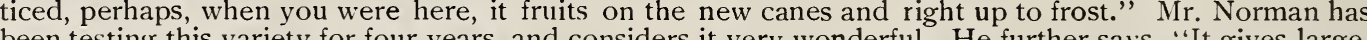
been testing this variety for four years, and considers it very wonderful. He further says, "It gives large, fine berries of excellent flavor. As to hardiness, it has stood 20 degrees below zero without protection."

Blackberry, Erskine Park Seedless. Of this Mr. Norman writes: "The Blackberry my notice was its hardiness. We always tie the canes up to their fruit stakes in the fall, never protect them at all, and as you know, they fruit right out to the tips of six-foot canes. I do not grow any other variety, for its long fruiting season enables me to trust to that variety alone. The fruit is the largest berry I know, fine flavor, no core, no seeds."

\section{CHOICE FRUITS}

It is a matter of pride with us that we can point to many large estates and fruit farms which we supply with select fruit trees. Although only small space is here given to a list of varieties, we are prepared to ship any varieties desired, and have selected below only a few of the choicest kinds, suitable for planting anywhere. Our fruit trees are grown by a reliable house of over fifty years' experience, and their name is a synonym for reliable fruit and best quality of stock.

Fruit trees should be well cut back when planted, and currants, gooseberries and peaches should be cut back every spring; some varieties of plums and pears need similar pruning for best results. To insure best treatment, we offer free, with every cash order of \$10 worth of fruit trees, Bailey's excellent book, "The Principles of Fruit-Growing," 5I4 pages, I20 illustrations; full directions as to selection of varieties, planting, tillage, harvesting and marketing, also renovating old orchards. On cash orders of \$15 we will send "The Pruning Book," by the same author. See page 47 of this Catalogue for description of the book. Special rates per I, ooo for orchard planting.

\section{APPLES}

Selected trees, 5 to 7 feet, first-class SUMMER

Early Harvest Red Astrachan Sops of Wine

Fa11 Pippin Gravenstein Wealthy
Sweet Bough

Yellow Transparent

Golden Sweet

\section{AUTUMN}

Fameuse, or Snow Apple Duchess of Oldenburg Red Bietigheimer

WINTER APPLES

Baldwin Greening

Newtown Pippin

Russett

Rambo

Sutton's Beauty

Hyslop Yellow Siberian

\section{CRAB APPLES}

Ben Davis

Hubbardston Nonesuch

Northern Spy

King

Twenty Ounce

Spitzenburg

Red Siberian Montreal Beauty 


\section{CHERRIES}

Selected trees, 5 to 7 feet, first-class

Black Oxheart

Black Tartarian

Early Richmond

Iay Duke

Reine Hortense

SWEET

Governor IVood

Napoleon Bigarreau

Windsor

SOUR

Montmorency

Olivet

Ostheim

\section{PEARS}

Selected standard trees, 5 to $7 \mathrm{ft}$.; Dwarf trees, 3 to $4 \mathrm{ft}$.

Those marked * grow best as dwarfs

Bartlett

Tyson

Kieffer

Doyenne d'Ete

Bosc (Beurre Bosc)

:Duchess

Seckel

IVorden-Seckel

\section{Clapp's Favorite}

*Anjou

Boussock

Beurre Clairgeau

Howell

Sheldon

Idaho

\section{PLUMS}

Selected, first-class

Coe's Golden Drop

German Prune

Imperial Gage

Lombard

IcLaughlin

Shropshire Damson

Yellow Egy

JAPANESE

Ogon

Satsuma

Burbank

Jaune Hative
Coe's Transparent

Souv. du Congress

RASPBERRIES

Cutlibert

Marlboro

Gregg

RED

Columbian

Erskine Park Everbearing

BLACK

Ohio

Kansas

STRAWBERRIES

Bederwood

Brandywine

Gladstone

Nick Ohmer

IIcKinley

Marshall

Parker Earle

Rough Rider

\section{CURRANTS}

Two-year-old plants, first-class

Black Naples

Cherry

Fay's Prolific

Pomona

Perfection (new)

Red Cross
Versailles
WVilder
White Grape

\section{GOOSEBERRIES}

Two- and three-year-old plants, first-class

Wyndam. English, imported plants.

Industry. This is the best red American variety.

Columbus. This is one of the most valuable introductions of recent years in small fruits, and it fully sustains the high opinion first formed of it. The fruit is of largest size, handsome, of a greenish yellow color, and the quality is excellent. The plant is vigorous and productive and does not mildew. It merits a place in every garden.

\section{NECTARINES}

Boston

Early Violet

Victoria

\section{PEACHES}

Selected trees, first-class
Crawford's Early

Morris White

Crosby (new)

Foster

Champion (new)

\section{QUINCES}

Rea's Iammoth

Orange

Crawford's Late

Mountain Rose

Elberta (new)

Hale's Early.

Oldmixon Free

Wonderful

\section{APRICOTS}

Acme

Harris

Ioorpark

\section{HARDY GRAPES}

BLACK

Concord

Hartford Prolific

Worden

Campbell's Early.

IVilder (Rogers" No. 4)

RED

Agawam (Rogers' No. I5) Brighton

Salem (Rogers' No. 53)

Lindley (Rogers' No. 9)

Catawba

WHITE

Niagara

IVinchell

Lucille (new)

Gærtner (Rogers' No. I4)

Ic Kinley

\section{BLACKBERRIES}

Snyder

Rathbun

Erie
IV'ilson's Junior
Stump the World

Erskine Park Seedless

\section{NUT TREES}

WALNUT

Black

Butternut

English

English, Dwarf

CHESTNUT

American Sweet

Numbo

Japanese

Paragon

Ridgley

Spanish

\section{ASPARAGUS}

Columbian Mammoth Conorer's Colossal Barr's Mammoth Palmetto

\section{RHUBARB}

Early Crimson Paragon
Mỵatt's Linnæus, best of all.

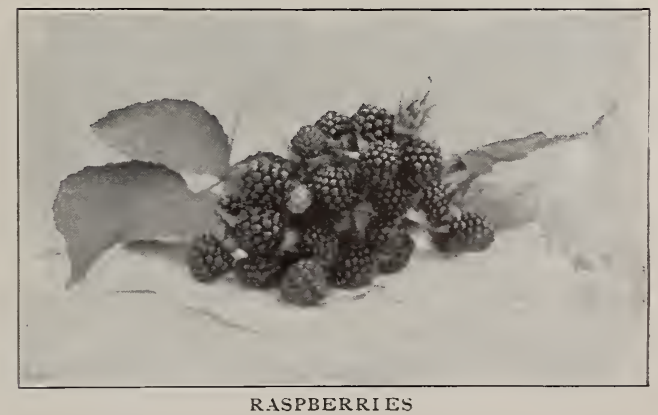




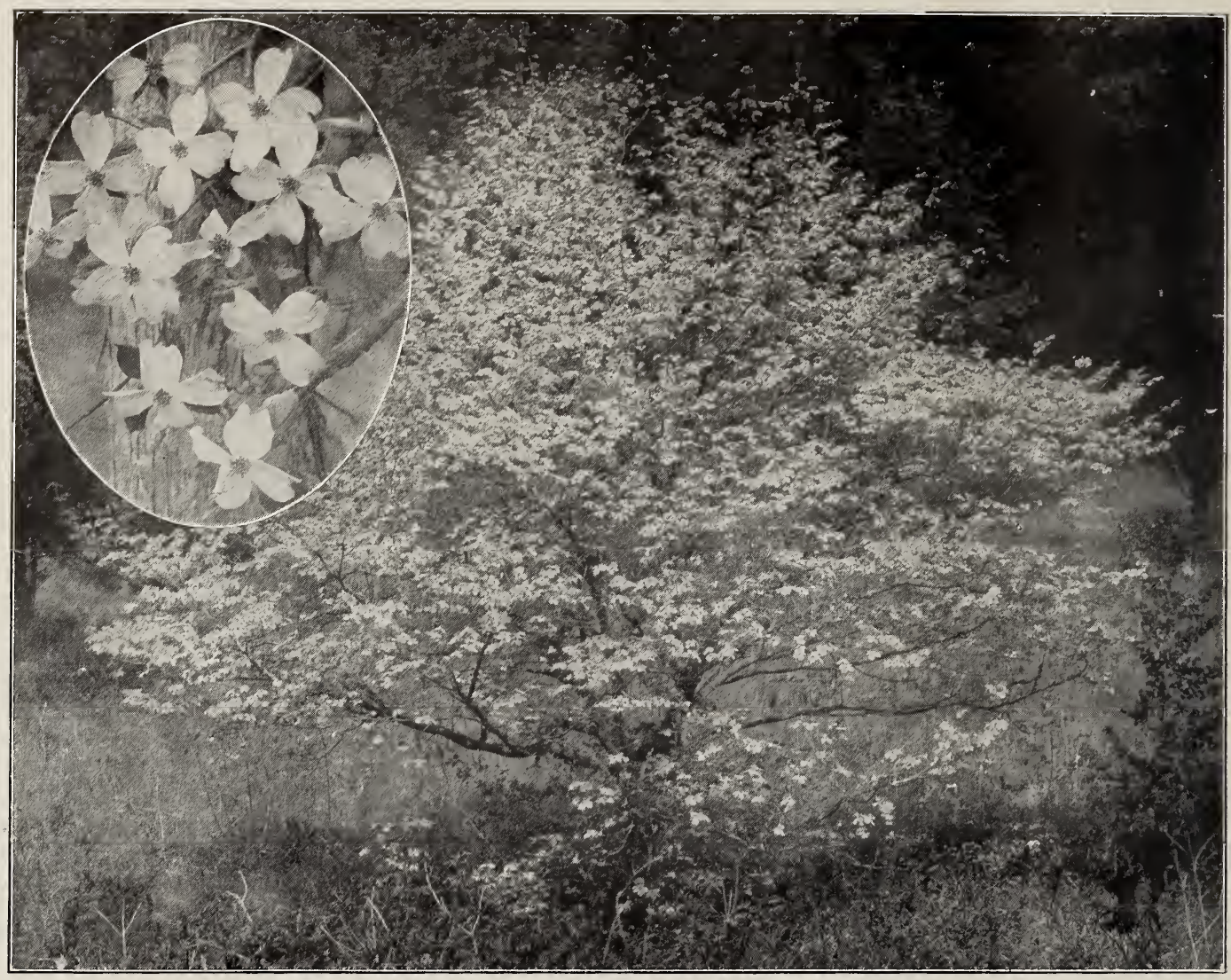

CORNUS FLORIDA TREE AND SPRAY OF BLOSSOMS. (See page 32,

\section{Ornamental Trees}

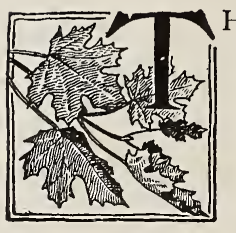

HERE is no department of our work in which we take more pride than this. We offer a magnificent stock of all the leading varieties in several sizes, including many specimen trees, both evergreen and deciduous. The more expensive evergreens are shipped with a ball of earth, which insures their success. A visit to our grounds will well repay intending purchasers.

We have successfully filled some unusually large orders, - one an order for 6,000 evergreens, another for 10,200 , and another for seven car-loads which included a great variety of both deciduous and evergreen. As such orders are not placed at random, it goes without saying that our stock is unexcelled. This means that it has been transplanted a sufficient number of times to produce good roots and has been given proper care in pruning and cultivation to produce proper form and size.

We would call particular attention to our Firs, Spruces, Pines, Retinosporas, Maples, Lindens, Birches, Planes, Oaks and Poplars.

\section{ACER. Maple}

There is no part of the landscape so neglected as the selection of trees. From fifty varieties of Maples often not more than five varieties are to be found on a large estate. There are four magnificent varieties of Norway Maples alone; three of the Sycamore Maple: six of the Japanese Maple, to say nothing of Wier's Cut-leaved, Sugar, Scarlet, and other well-known varieties. Prices will vary according to size and kinds.

Grand stock; prices low; sizes up to 20 feet Acer dasycarpum. White, or Silver Maple. This is not only the largest, but most rapid-growing Maple. Moderate trimming the first few years will give it fine shape.
Acer dasycarpum Wierii. Wier's Cut-leaved Silver Maple. One of the best Maples in cultivation. Rapidity of growth, graceful and airy form, and abundant silvery foliage give it rank among the most attractive lawn trees.

A. platanoides. Norway Maple. On account of its stout, vigorous growth, rounded and symmetr cal form, and deep green shining foliage-which remains on late in autumn-this tree has become very popular, not only as a lawn tree, but also for street planting.

A. p. laciniatum. Eagle's Claw Norway Maple. A small-growing variety of the Norway, whose leaves are deeply lobed and sharply pointed, resembling an eagle's claw. 
Acer platanoides Reitenbachi. Reitenbach's Norway Maple. An excellent, medium-sized variety, valued for its highly colored foliage in summer and autumn.

A. p. Schwedleri. Purple Norway Maple. Young shoots and leaves of a bright crimson color, changing to purplish green in the older leaves.

A. Pseudo-platanus. European Sycamore Maple. Well-known rapid-growing tree; large, green foliage.

A. P. foliis atropurpureis. Dark, purple-leaved Sycamore Maple. Pretty ornamental tree on account of the deep purple color on the under side of the leaves.

A. P. tricolor. Tricolored Sycamore Maple. This is one of the most showy of all Maples, except the dwarf Japanese varieties. Leaves are distinctly mottled with three shades of green; no two leaves alike in color.

A. P. Worlei. Worle's Golden-leaved Sycamore Maple. Foliage golden yellow in spring. The young growth continues brilliant throughout the summer; very effective planted with Schwedler's variety.

A. saccharinum. Sugar, or Rock Maple. Although a little slower in growth than most large Maples, its compact and stately growth, high color in autumn, and resistance to strongest winds renders this second to none as a street tree.

\section{JAPANESE MAPLES}

Like most other plants introduced from Japan, thes have become very popular. The demand is so great that prices are nearly double those of other Maples. Attaining small size ( 6 to 15 feet in height), beautiful form and foliage, which is often very highly colored, they are graceful either singly or in groups.

Acer polymorphum. This is the parent form of many Japanese Maples in cultivation. Its leaves are green and feathery, changing to a lovely dark crimson in autumn.

A. p. atropurpureum. Dark Purple-leaved Japan Maple. Foliage dark purple, deeply cut; one of the very best small trees in cultivation.

A. p. dissectum atropurpureum. Cut-leaved Purple Japan Maple. Very dwarf. Leaves beautiful rosecolor when young; change to a deep and constant purple. Drooping, delicate and deeply cut foliage gives it an elegant fern like appearance.

A. p. nigrum. Similar to Atropurpureum, except that the foliage is almost black.

A. p. palmatum. Palm-leaved Japan Maple. Leaves 5- to 7-lobed, deep green, changing to crimson at autumn. Upright; very compact.

A. p. sanguineum. Blood-leaved Japan Maple. Reddish crimson in June; foliage five-lobed and serrated.

A. p. roseum marginatum. Dwarf, attractive sort. Leaves are tipped or bordered with rose.

\section{AESCULUS. Horse-Chestnut}

From seven varieties I select two of the best. The absence of fruit and litter is greatly in their favor.

AEsculus rubicunda. Red-flowering.

AE. fl. pl. Double-flowering.

\section{ALNUS. Alder}

Alnus glutinosa laciniata imperialis. A stately tree with deeply cut foliage. Excelled by none as a specimen tree.

\section{AMYGDALUS. Almond}

Amygdalus communis roseo fl. pl. Large, doubleflowering Almond; vigorous grower, covered with double rose-colored blossoms in May.

\section{BETULA. Birch}

Betula alba. Rapid in growth and highly graceful in form; its drooping branches render the tree very attractive in landscape.

B. fastigiata. Pyramidal Birch. Bark silvery white elegant pyramidal habit like the Lombardy poplar.

B. pendula laciniata. Unique and highly ornamental not only on account of the silvery white bark, but also for the pleasing lightness and airiness of its foliage. It is this variety which Coleridge pronounces "the most beautiful of all forest trees," "The Lady. of the Woods."
Betula pendula Youngii. Young's Weeping Birch. Grafted on stems 5 or 6 feet high, its branches droop gracefully to the ground.

B. papyracea. Paper, or Canoe Birch. This is the native Birch used by the Indians in the construction of their canoes. In many respects this is the best of white-barked Birches. Bark is pure white, leaves large, growth rapid.

\section{CASTANEA. Chestnut}

Castanea vesca. There are no other trees so well adapted for avenues that will at the same time yield profitable returns for the land occupied as our native nut-bearing trees, and none more suitable for shade and ornament about farm buildings, along farm lanes or in pasture fields. The difficulties attending the grafting and transplanting of them are the greatest obstacles in the way of their more general cultivation. Numbo, Spanish and Paragon are two of the best and most productive kinds with very large nuts.

\section{CATALPA}

Catalpa speciosa. Finer and hardier than the southern variety. Blooms in July.

C. Bungei. Of dwarf habit, growing 3 to 5 feet high. Top-grafted or standard; is very effective. Standard top-grafted, I-year, 2-year and 3 -year heads, 6 to 8 feet. See photo-engraving, page 32 .

\section{CERASUS. Cherry}

A very ornamental family of flowering trees. Among the ten varieties it is difficult to select. We call attention to three upright and two weeping as especially desirable.

Cerasus Japonica pendula. Feathery and graceful flowers, single white.

C. J. rosea pendula. Branches slender, and fall gracefully to the ground. Flowers rose-colored and appear before the leaves.

C. Rhexi fl. pl. A fine double, white-flowered variety, appearing like a huge bouquet of small roses.

C. Sieboldi rubra plena. Semi-double; white flowers tinged with red.

C. Sinensis fl. pl. Chinese Double-flowered Cherry. Very fine, with large double white flowers.

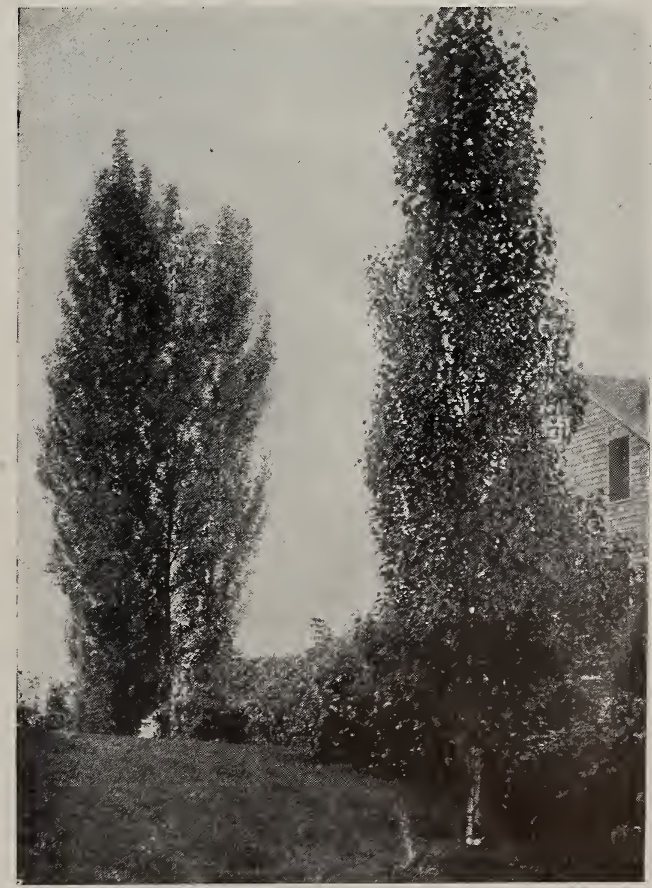

LOMBARDY POPI.AR PYRAMIDAL BIRCH 


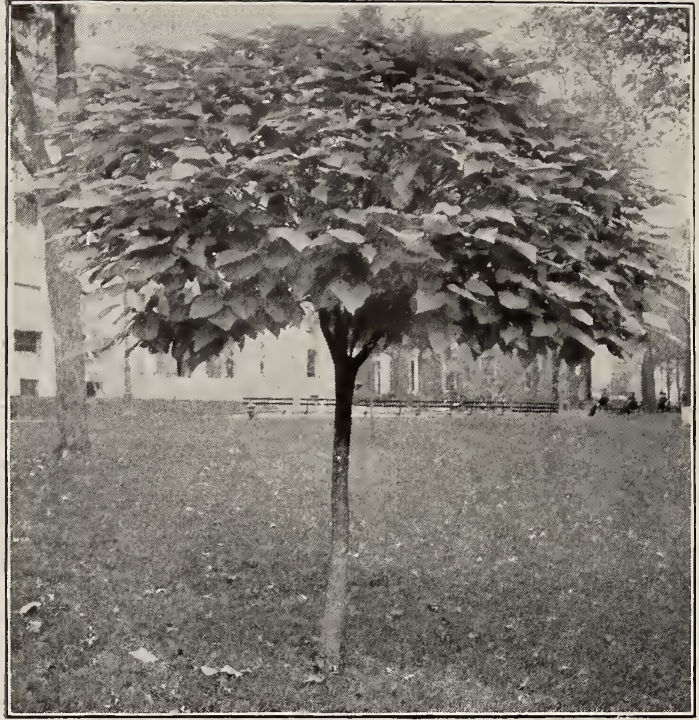

CATALPA BUNGEI (See page 3r)

\section{CHIONANTHUS. White Fringe}

Chionanthus Virginica. No small tree surpasses this in flower or foliage; blossoms in May.

\section{CERCIS. Red Bud}

Cercis Canadensis. This is valuable as an ornamentai tree, no less on account of its exceedingly neat foliage, which is exactly heart-shaped and of a pleasing green tint, than for its pretty pink blossoms. It is one of the most ornamental trees, and a fine effect is produced by planting it with the Magnolias and Dogwoods.

C. Japonica. Japan Judas Tree. This is especially desirable in certain places because of its smaller size. Flowers literally cover the branches before the leaves appear, and their rich reddish purple flowers are unique. Foliage is very beautiful.

\section{CLADRASTIS. Virgilia}

Cladrastis tinctoria. Yellow-wood. No description can do this tree justice. Medium in size; compound foliage; racemes of sweet-scented white blossoms in June. It is certainly one of the most beautiful of flowering trees. Each leaf is composed of seven or eight leaflets 3 or 4 inches long, the whole leaf being more than a foot in length. These expand late in spring about the middle of May, and are followed by numerous clusters of charming and pea-shaped blossoms, pure white. These clusters are 6 to 8 inches in length. The flowers are daintily formed and arranged in a gracefully loose and easy manner. The tree grows very rapidly and is very agreeable in form and foliage even when young.

\section{CORNUS. Dogwood}

Cornus florida. White Dogwood. Grows from 20 to 30 feet in height. No medium-sized tree excels in beauty this native tree, whether viewed at the time of its beautiful bloom in early spring, its massive glossy green foliage in summer, or its gorgeous coloring of fruit and foliage in autumn. The whole tree assumes a deep lake red. The flowers, which appear as those of the Magnolias are falling, maintain a succession of bloom about two weeks. In autumn coloring, it is unrivaled except by the Scarlet Oak.

C. rubra. We have been trying for some time to get sufficient stock of this tree to supply the great de mand, and yet we fear that only early orders will be honored.

C. pendula. Weeping Dogwood. Unique.

\section{CRATAEGUS. Thorn}

The Thorns, comprising many varieties, are classed among the most beantiful flowering trees of low growth. In front of old evergreens their flowers and foliage are shown to the highest advantage, and in autumn their fruit is highly effective. Their sweet-scented flowers appear in great profusion in May and June.

Crataegus Oxyacantha fl. pl. Double IVhite Thorn. This variety, with its small double white flowers, makes a striking contrast with the Double Scarlet. C. O. coccinea fl. pl. Pauli. Paul's Double Scarlet Thorn. Flowers light red. Best of its color.

\section{CYTISUS}

Cytisus Laburnum. Golden Chain. A native of Europe; foliage smooth and shining. The name Golden Chain alludes to the long drooping racemes of yellow flowers, which appear in June.

\section{FAGUS. Beech}

For specimen trees on the lawn, no tree surpasses the Beech. They are beautiful from the first, but in a few years they are superb. Where room is given for a large tree to develop, the common American Beech gives a magnificent specimen. It has smooth gray bark and shining oval leaves, making it beautiful in summer, and in winter the smooth gray bark makes it distinctive among trees.

Fagus ferruginea. American Beech.

F. sylvatica. European Beech.

F. s. heterophylla. Fern-leaved Beech. A small tree with fern-like foliage. Its young, shoot-like tendrils give it a graceful aspect.

F. s. pendula. Weeping Beech. A grotesque, largegrowing tree.

F. s. purpurea Riversii. The finest of all purpleleaved trees.

F. s. purpurea pendula. Weeping Purple-leaved Beech. Habit similar to the IVeeping Beech.

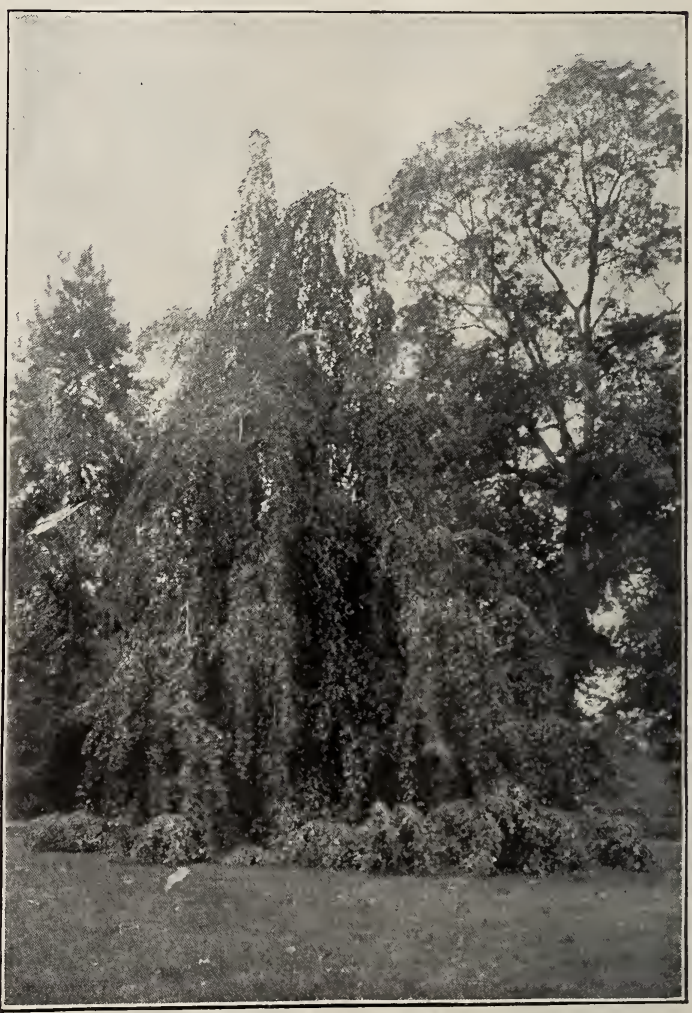

WEEPING BEECH 


\section{KOELREUTERIA}

Koelreuteria paniculata. A hardy, small, roundheaded tree from China. Its large vellow flowers in July, when nearly all other trees are out of bloom, make it especially desirable.

\section{LARIX}

Larix Europaea. European Larch. One of the most attractive lawn trees in spring because of its early deep green foliage, followed by purple cones.

\section{LIQUIDAMBAR}

Liquidambar styraciflua. Sweet Guin. One of the finest American trees. Form symmetrical; beautiful in foliage, and especially attractive in autumn when it is decked in colors almost too bright and vivid for foliage. The prevailing tint is a deep purplish red, sometimes varied by a shade deeper or lighter, and occasionally an orange tint is assumed. Planted near other trees remarkable for their autumnal coloring, the effect is almost magical. It grows well in moist and even wet situations, although it will accommodate itself to a drier soil.

\section{MACLURA}

Maclura aurantiaca. Osage Orange. This interesting tree, a native of the Mississippi valley, attains a height of 50 to 60 feet. The blossoms are greenish; the fruit about the shape and size of a large orange, but the surface is very rough. The bright glossy hue of its foliage and especially the unique appearance of a good-sized tree covered with large orange-like fruit render it one of the most interesting of our native trees.

\section{MAGNOLIA}

Magnolia macrophylla. Great-leaved Magnolia. A superb species; leaves 2 feet in length, giving it a tropical effect. Flowers, appearing in June, are from 8 to Io inches in diameter.

M. tripetala. Umbrella Tree. A medium-sized tree, with immense leaves and large flowers, appearing in June.

M. conspicua. Flowers large, pure white, and rery fragrant.

M. Soulangeana. In habit resembling Conspicua; shrubby and branching when young, but becoming a fair-sized tree. Flowers white and purple, 3 to 5 inches in diameter. Blooms later than Conspicua.

M. speciosa. Showy-flowered Magnolia. Blooms a week later than Soulangeana and flowers remain upon the tree longer than those of any other variety.

M. stellata. Hall's Japan Miagnolia. This is a very dwarf grower and blooms in April. Its double white fragrant flowers make it one of the most desirable.

\section{MORUS. Mulberry}

Morus Tatarica pendula. Weeping Russian IIulberry. The finest umbrella-shaped tree. Its slender branches droop to the ground.

\section{PAULOWNIA. Empress Tree}

Paulownia imperialis. A magnificent tropical-like tree from Japan. It surpasses all others in size of its leaves, which are from 12 to 14 inches in diameter. Cut back every spring it may be kept low, and the leaves will be much larger.

\section{PERSICA. Peach}

The double-flowering Peaches are among the choicest flowering trees, literally covering many of the branches in May with large double flowers. They will bloom the second year.

Persica vulgaris alba pleno. Double white. P. v. rosea. Double rose.

P. v. sanguinea pleno. Double red: superb.

\section{PLATANUS. Plane Tree}

Platanus orientalis. Oriental Plane. Rapid-growing tree of the very largest size. No tree was in greater esteem with the ancients. IVe are told that the Academic groves, the neighborhood of the public schools, and all those favorite haunts where the Grecian philosophers were accustomed to resort, were planted with these trees; and beneath their shade Aristotle, Plato and Socrates delivered the choicest wisdom and eloquence of those classic days." The great merit of the Plane tree is its extreme vigor and luxuriance of growth and ease of transplanting. In a good soil it will readily reach a height of 35 to 40 feet in ten years.

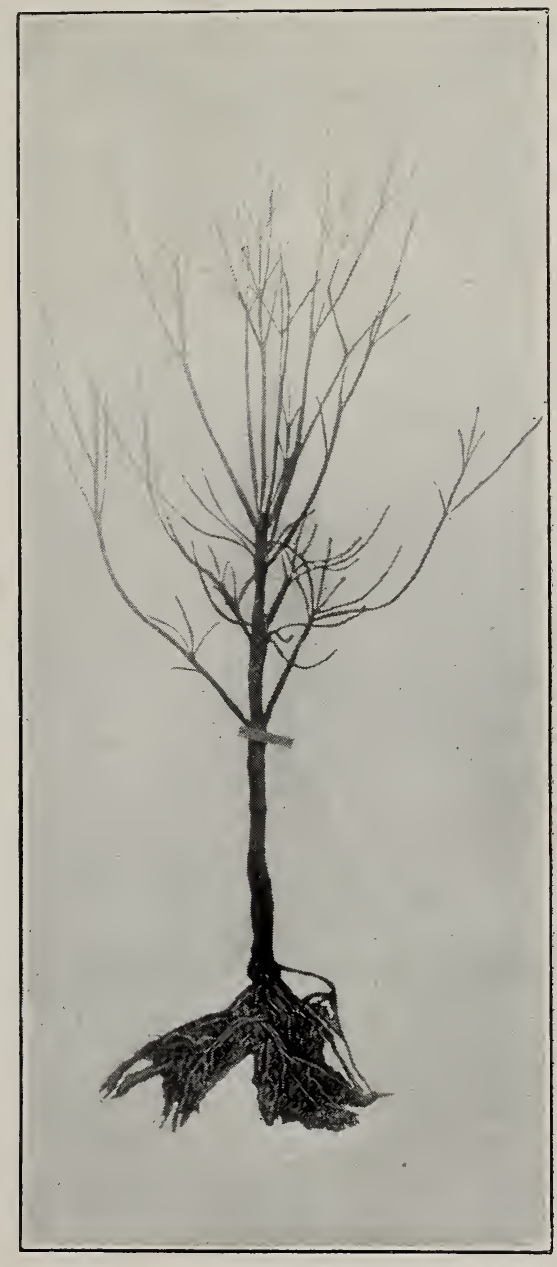

RED-FLOWERING DOGWOOD (See page 32)

\section{PYRUS. Crab}

Pyrus angustifolia. Bechtel's Double-flowering Crab. Tree of medium size, blooms young. The double flowers are sometimes mistaken for pink roses. Their fragrance tends to increase the delusion.

P. Malus Parkmani. One of the most beautiful recent introductions from Japan. Flowers very double, dark rose, dangling gracefully on slender stems, retaining their color until they drop.

P. M. spectabilis alba fl. pl. Chinese Double White-flowered. Double white, fragrant flowers in clusters in May.

P. M. s. rosea fi. pl. Has double rose-colored, fragrant flowers learly 2 inches in diameter, in May. 


\section{POPULUS. Poplar}

Some of the American Poplars, as the Balsam and Gilead Poplars, have their buds enveloped in a fragrant gum ; the Lombardy Poplar "shoots up its spire and shakes its leaves in the sun." It is remarkable for its conical and spire-like manner of growth. The Lombardy Poplar is a beautiful tree and in certain situations produces a very elegant effect. It may be employed with singular advantage in giving life and variety to a scene composed entirely of round-headed trees. It may also, by its striking and marked contrast to other trees, be employed to fix the attention to some particular point in the landscape.

Populus Bolleana alba. A very compact grower, resembling in form the Lombardy, with leaves glossy green above and silvery beneath.

P. alba. Abele, or Silver Poplar. More wide-spreading than any of the other Poplars. Leaves glossy dark green above and pure white beneath.

P. monolifera. Carolina Poplar. One of the best for street planting and for screens.

P. fastigiata. Lombardy Poplar. Majestic in form and size, attaining a height of 150 feet. A remarkably erect, rapid grower.

\section{QUERCUS. Oak}

From many species and varieties we select five of the best of the Oaks. No tree can fill the place of the Oaks. Let none hesitate to plant this sturdy tree because of its slow growth. It is grand even when young.

Quercus palustris. Pin Oak. Grows to a height of 60 to 80 feet, is hardy and grows rapidly upon moist soils.

Q. coccinea. A noble tree of rapid growth, often 80 feet high. Native in the middle states. The great beauty of this tree is its deep scarlet tint in autumn. when it may be distinguished at a great distance from all other forest trees.

Q. Robur. English Oak. A well-known tree of spreading slow growth.

Q. R. Concordia. Golden Oak. A superb variety which retains its color throughout the season. The best golden-leaved tree.

Q. R. fastigiata. Evergreen Oak. A remarkable medium-sized tree of pyramidal habit, like the Lombardy Poplar. Foliage spotted with silver. Superb.

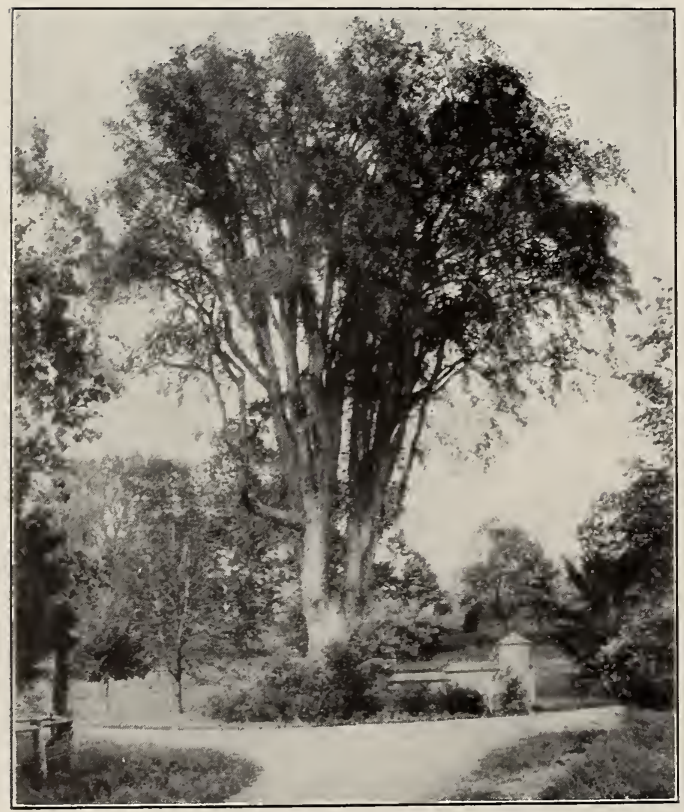

THE AMERICAN ELM

\section{ROBINIA. Locust or Acacia}

Robinia hispida. Rose or Moss Locust. A native, spreading, irregular tree, with long elegant clusters of rose-colored flowers in May and at intervals all the season.

R. pseudacacia. Black or Vellow Locust. The value of this tree lies in its extremely rapid growth when young, as during the first ten or fifteen years it exceeds in thrifty shoots almost all other forest trees; but it is short-lived, and in twenty years' time many other trees would completely outlive and outstrip it.

\section{SALISBURIA. Maidenhair Tree}

Salisburia adiantifolia. A picturesque tree of rapid growth. The foliage is fern-like, whence its name rare and beautiful; perfectly hardy south of Albany. This tree is so great a botanical curiosity and so singularly beautiful, the form and outline so pleasing and harmonizes so well with buildings, that it should be planted near the house, where it may be readily seen and appreciated.

\section{SALIX. Willow}

No trees are so little known as the IVillows. Easily transplanted, of exceedingly rapid growth, and of fine habit. These are strong arguments in their favor.

Salix Babylonica. The well-known Weeping Willow from Asia.

S. B. ramulis aurea. Golden-barked Weeping Wil low. Habit same as the type, but has beautiful golden bark in winter.

S. regalis. Royal Willow. Elegant tree, with rich silvery foliage. Very effective in groups.

S. rosmarinifolia. Rosemary-leaved Willow. A rery striking and beautiful tree, with feathery branches and silvery foliage.

S., Wisconsin Weeping. Of drooping habit. Valuable on account of its ability to resist severe cold

\section{TAXODIUM. Deciduous Cypress}

Taxodium distichum. A native of the South; perfectly hardy to a latitude of 43 degrees; a distinct tree of rapid pyramidal growth and soft feathery foliage of bright green tint in loose, airy tufts, which give it a character of elegance. With other trees the Cypress produces a pleasing effect, especially with hemlocks and firs, with which it harmonizes well in form and foliage, while its light green is beautifully opposed to their richer and darker tints. Of rapid growth.

T. d. pendulum. A fine weeping sort.

\section{TILIA. Linden}

The Lindens are symmetrical in form, rapid in growth and of great beauty when given room to develop naturally. The flowers are large, handsome and heart-shaped in form; ther open in June, hang in loose pale yellow clusters, and are quite ornamental and very fragrant

Tilia Americana. American Linden.

T. Europaea. European Linden Broad-leaved.

T. E. alba. White-leaved Linden. Particularly noticeable among trees by its white appearance. A beautiful tree with large foliage and symmetrical form. T. E. alba pendula. Weeping Linden. This is one of the best of weeping trees. It droops just enough to be graceful.

T. E. alba spectabilis. This differs from the white leaved in having larger leaves, but not so downy beneath.

\section{ULMUS. Elm}

Ulmus Americana. American Elm. This tree is a rapid grower, long-lived, attains a large size, and its umbrella form gives shade while it does not obstruct the view. No more majestic tree either for lawn or street than this. It often reaches a height of 80 to 100 feet and a diameter of 40 to 50 feet. The charming villages of New England, including Lenox and Stockbridge, attain a greater portion of their peculiar loveliness from the wonderfully beantiful elms which decorate their fine streets. Very easilj transplanted. 


\section{Shrubs in Tree Form or Standards}

The increasing interest in formal gardening has created a great demand for shrubs grown in tree form. They are rery effective in formal yardens, bordering walks or in lines back of the bush forms.

Standard Bay Trees and Box are more satisfactory in tubs. Other kinds named below may be grown as easily in the open ground as are the same species in bush form. Stems about 3 to + feet high.

AZALEA mollis. See description on page 43 .

BOX (Buxus semperirens). See under Evergreen Shrubs, page 4I.

CATALPA Bungei. See Deciduous Ornamental Trees, page $3 \mathrm{I}$.

FORSYTHIA. See page 44.

HIBISCUS (Althea). See Shrubs, page 44 .

H Y D R A NGE paniculata grandiflora. This plant is very effective and showy for center of beds or rear of borders.

LIGUSTRUM. Privet. Useful for formal gardens, or other decoration where Bay trees are used. Stems 4 to 5 feet; heads, 2 to 3 feet.

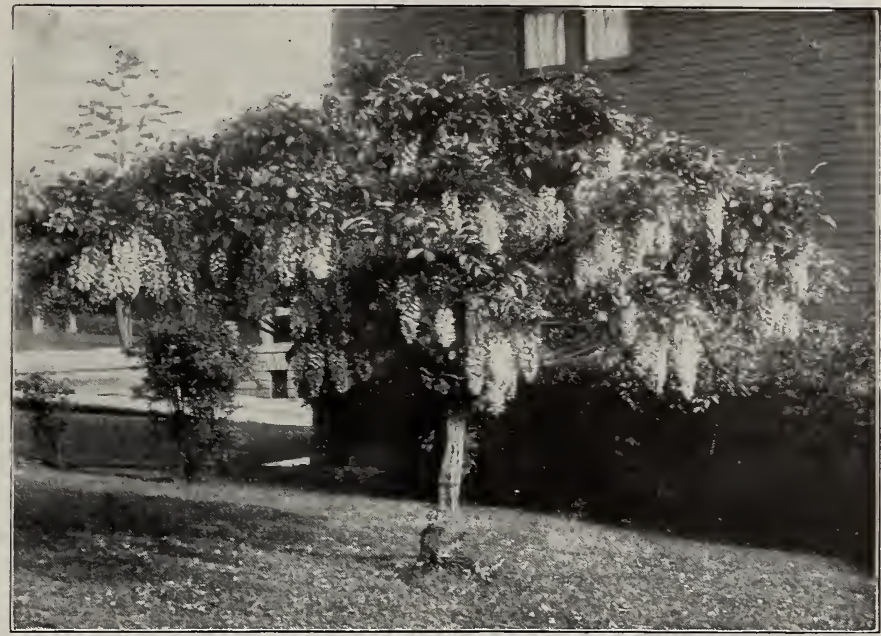

STANDARD WISTARIA

LILAC. Very fine pot-grown plants, 5 feet high, set with bloom-buds.

VIBURNUM plicatum. Japan Snowball. Stout stem, well-branched head; fine for immediate effect.

WISTARIA. Very showy as a specimen plant.

\section{LAURUS NOBILIS. Bay Trees}

\begin{tabular}{|c|c|c|c|c|c|c|c|c|}
\hline \multicolumn{4}{|c|}{ STANDARDS } & & \multicolumn{4}{|c|}{ PYRAMIDS } \\
\hline CROWN & STEMI & TALL & TUB & PRICE & TALL & DIAMETER AT BASE & TUB & PRICE \\
\hline 28 to $30 \mathrm{in}$. & $4^{8} \mathrm{in.}$ & $7 \frac{1}{2} \mathrm{ft}$. & I $5 \mathrm{in.}$ & $\$$ IO OO & $6 \mathrm{ft}$, , io in. & 26 to 48 in. & I3 in. & $\$$ IO 00 \\
\hline 32 to 34 in. & $48 \mathrm{in.}$ & 7 to Io $\mathrm{ft}$. & I 7 in. & 1250 & $\begin{array}{l}0 \mathrm{ft} ., \text { Io in. } \\
8 \mathrm{ft}, 6 \mathrm{in} .\end{array}$ & $\begin{array}{l}42 \text { in. } \\
34 \text { in. }\end{array}$ & $\begin{array}{l}\text { I } 8 \text { in. } \\
\text { I } 7 \text { in. }\end{array}$ & $\begin{array}{l}1250 \\
1500\end{array}$ \\
\hline 34 to 36 in. & $48 \mathrm{in.}$ & $\tau$ to $10 \mathrm{ft}$. & I 7 in. & 1500 & $7 \mathrm{ft} ., 6$ in. & 48 in. & $20 \mathrm{in}$. & 2000 \\
\hline $3:$ to $40 \mathrm{in}$. & $48 \mathrm{in.}$ & $8 \mathrm{ft}$ & I 8 in. & I8 00 & $9 \mathrm{ft}$. & $48 \mathrm{in}$. & $21 \mathrm{in}$. & 4000 \\
\hline 40 to 42 in. & 45 in. & $8 \mathrm{ft}$. & $20 \mathrm{in.}$ & 2000 & & COLUMN & & \\
\hline $4^{8}$ in. & $45 \mathrm{in.}$ & $8 \mathrm{ft}$. & $2 \mathrm{I}$ in. & 2250 & $9 \mathrm{ft}$. & $28 \mathrm{in.}$ & 17 in. & 2500 \\
\hline
\end{tabular}

\section{Hedges}

Hedges are becoming more popular, and justly so, for they combine beauty with usefulness. Moreorer, the cost is less than for a substantial fence. At Newport, the most beautiful summer resort in America, hedges are abundant, and walls and fences are becoming a thing of the past. At Elberon, Ocean Grove and Long Branch are miles of Privet, and the effect is fine. We make a specialty of hedge plants and can furnish the best by the Io,ooo rate.

\section{UNTRIMMED HEDGES}

Berberis Thunbergii. Japanese Barberry. Of dwarf, graceful habit and very thorny; this is one of the best plants for an untrimmed hedge. It need never be touched with the shears. Its small leaves assume a gorgeous crimson color in autumn (though beautiful at all times), but its fruit is its most attractive feature. The slender branches droop beneath their load of red berries, which hang on all winter. As it never grows over 3 or 4 feet high, it is fine for the edge of terrace and along roads and walks, and, being as thorny as a gooseberry bush, boys and animals will let it alone. Plant 15 inches apart.

Mahonia Aquifolium. Beautiful at all seasons of the year: in winter the prickly; shiny, purplish leaves turn to the finest bronze and crimson. "In spring the whole picture changes, the polished leaves are green again, and the bushes are full of tufted masses of brilliant yellow bloom, and fuller of bee music than any other plant then in bloom." Grows 4 or 5 feet high. Plant is inches apart.

\section{TRIMMED HEDGES}

Buxus sempervirens. See page $4 \mathrm{I}$.

Hemlock Spruce. Undoubtedly the best evergreen hedge. Perfectly hardy, it bears the shears well, and keeps its rich green color all winter. No matter how severely it is trimmed, its new growth is feathery and graceful. Plant 18 inches apart for low hedge and 2 feet for high one.

California Privet. This is the most popular plant for a trimmed hedge, because of its low price and rapid growth. It will grow right up close to a large tree, where others will not. It holds its foliage until midwinter and bears the shears well. Plant 8 inches apart. Our plants are grown on sandy loam, which gives many fibrous roots.

Rosa rugosa. Japanese Rose. The glossy green foliage and large single red flowers, followed by the large red heps, which hang on into winter, make this one of the most attractive hedge plants.

Norway Spruce and Arborvitae make a cheap, tall-growing hedge for shelter.

\section{Trees for Formal Effect}

Rose Trees (page 12); Birch (page 3I); Catalpa (page 3I); Evergreens, Arborvitae, Yews, Etc. (pages 36 to 39 ); Poplars (page 34 ); Shrubs in Tree Form (page 35 ). 


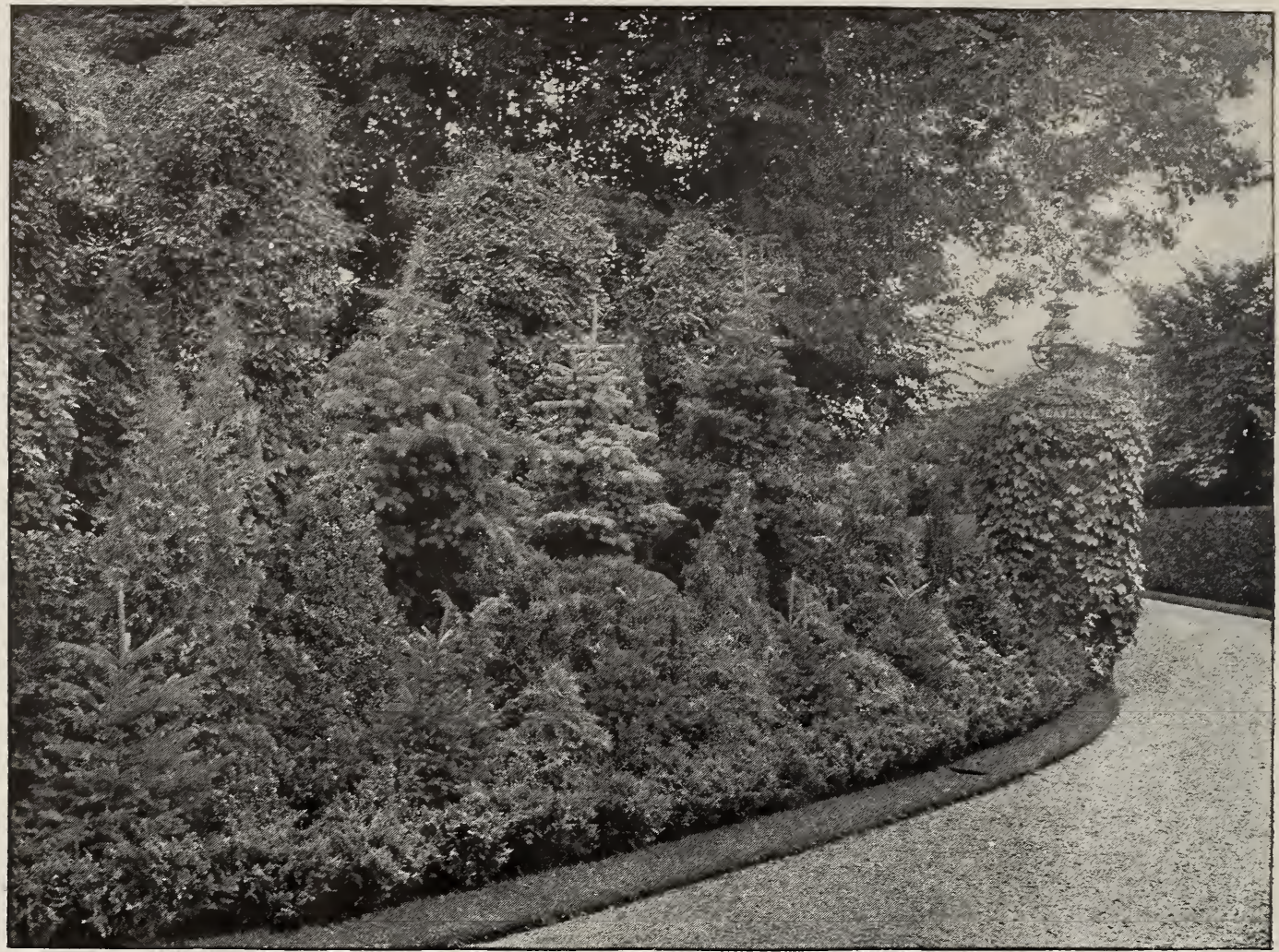

EVERGREENS MAKE A MOST EFFECTIVE ENTRANCE

\section{Cone-bearing Evergreens}

A PINETUM

A collection of Pines, Firs and other evergreens planted where they may be allowed to develop themselves in their full beauty and proportion, called a Pinetum, not only adds great beauty to a large estate because of its contrast of forms and its peculiarities, but permits of growing many more delicate species which if exposed singly would perish. It is becoming customary on many fine country estates to select an extensive and suitable locality where all the species may be collected together. To those who have not seen such a planting, it is scarcely conceivable how much they add to the beauty of a country residence in winter. In exposed quarters, also in all bleak situations, groups of evergreens form the most effectual shelter at all seasons of the year. Noreover, many of them may be recommended to grow upon the most meager soil.

The effect produced by evergreens, although the plants may be of small or medium size, is immediate. The symmetrical form and beauty of verdure of young plants is no less effective than the picturesque beauty of the rugged and time-worn tree. No material, therefore, is more adapted for planting new places than are evergreens.

Planters should be cautioned about planting too large sizes.

\section{ABIES. Fir}

Abies concolor. Silvery Fir of Colorado. Tree of graceful habit; bright handsome foliage, bluish above, silvery beneath; very distinct and exceedingly rare. This is one of the best Fir trees, which withstands heat, drought and cold. It is very hardy, grows rapidly and rivals the Nordmanniana in beauty.

A. Nordmanniana. Nordmann's Silver Fir. This variety is native in the mountains of Crimea, where it attains a height of 100 feet. The foliage is of the darkest green, silvered underneath, retaining its color throughout the year. It contrasts well with lighter evergreens, is very hardy and of rapid growth.

\section{JUNIPERUS. Juniper}

All the Junipers are valuable or namental plants-the upright species as single specimens or in groups, and the low forms well adapted for rocky slopes or banks. Junipers thrive best in a sandy, loamy soil, moderately moist, but do well in rocky and gravelly soils in sunny, open situations. Excellent for seaside planting.

Juniperus communis Hibernica. Irish Juniper. Neat and effective with other small evergreens.

J. Japonica. Japan Juniper. Native of China and Japan. A dwarf, dense, bushy evergreen with light green foliage; forms a compact bush 3 to 5 feet in height. 
Juniperus Japonica aurea. Variety of the preceding; the vounger growth tinged with golden yellow, which it retains throughout the summer.

J. J. variegata alba. Silver Variegated Japan Juniper. Dwarf, dense, bushy evergreen, with glaucous green foliage interspersed with branches of a pure white tint; very hardy.

J. prostrata. Prostrate Juniper. Well adapted for covering rocks, since it rises only a few inches high and covers a considerable area with a thick carpet of verdure.

J. Sabina. Savin's Juniper. Dwarf-spreading shrub with trailing branches. Grows in the poorest soil.

J. squamata. Scaled Juniper. Low and spreading ; suitable for rockwork.

J. communis Suecica. Swedish Junipe.. A native of northern Europe. Conical, upright-growing bush, from I2 to 20 feet. Very hardy.

J. Virginiana. Red Cedar. Fine for hedge plants.

\section{PICEA. Spruce}

Picea alba. White Spruce. A native tree of medium size, varying in heiglit from 25 to 50 feet. Of pyramidal form; very shapely in appearance. The foliage is silvery gray; one of the hardiest of evergreens and is adapted to sections where many others would fall. IVill thrive in light, moist soils.

P. Alcockiana. Alcock's Spruce. Foliage pale green, silvery underneath. One of the choicest ornamental evergreens as a specimen on the lawn. Rapid grower, bears cones when young.

P. Douglasii. Douglas' Spruce. A rapid-growing tree with nice deep green foliage. We offer the hardy Colorado variety.

P. excelsa. Norway Spruce. No evergreen is more generally planted than this because of its exceedingly rapid growth and extreme hardiness, which adapt it for shelter and massing for effect. It will grow 3 feet annually when well established.

P. e. inverta. IVeeping Norway Spruce. Very grotesque, with foliage lighter and brighter than the species.

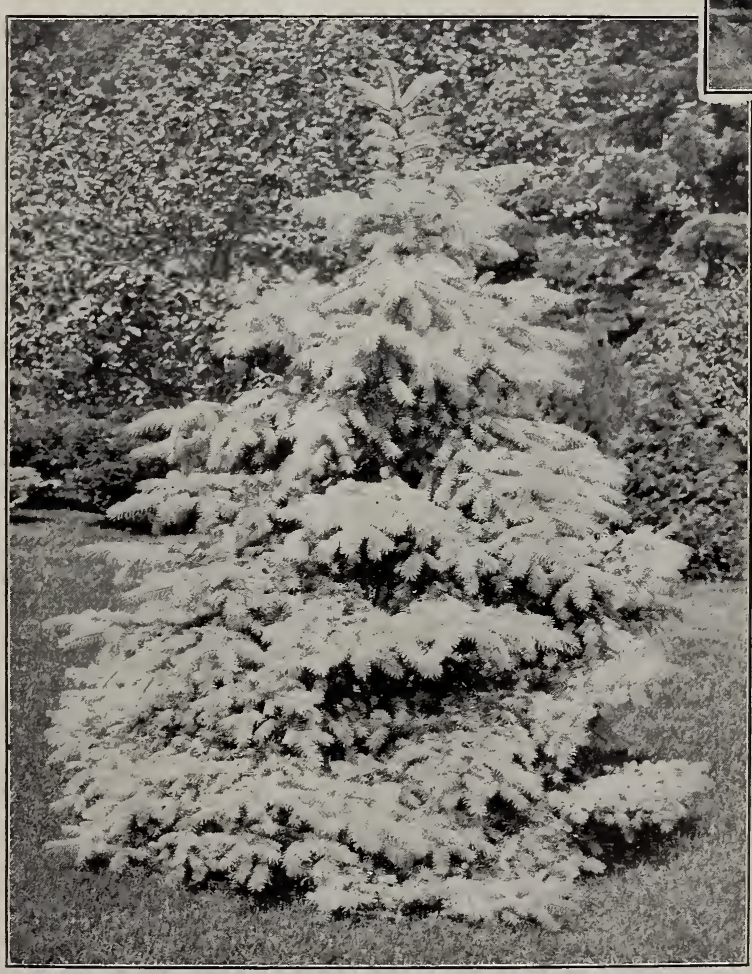

KOSTER'S BLCE SPRTCE

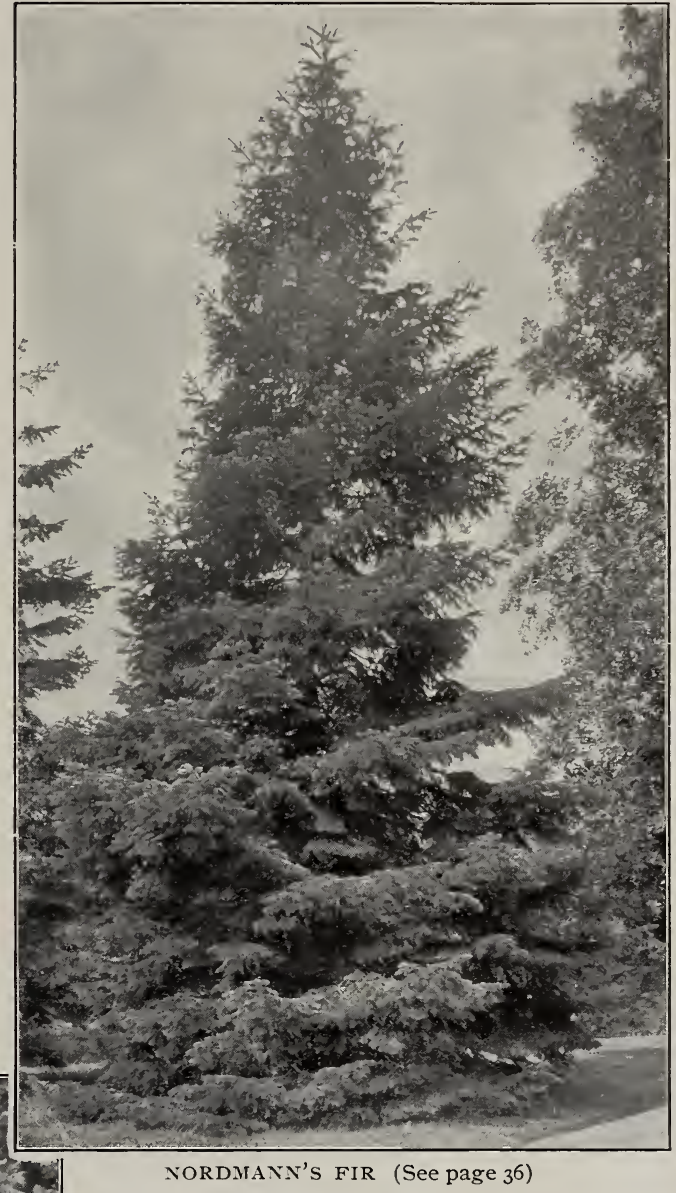

Picea orientalis. Eastern Spruce. Foliage smaller and more dense than that of the other Spruces; color deep glossy green, brighter and richer than the Norway Spruce; hardy as far north as Boston. Attains a height of 50 to 60 feet. We consider this one of the most elegant of all the conifers.

P. polita. Tiger-tail Spruce. A distinct Japanese species from the Island Nippon It is of erect and conical habit and graceful in outline. It is a very hardy, free grower and accommodates itself well to our climate. Somewhat drooping in old age.

P. pungens glauca. Selected blue seedlings. P. p. g. Kosteri. Koster's Colorado Blue Spruce. This we consider one of the finest native evergreens; in fact, no finer evergreen exists. Foliage of the richest blue or sage color; perfectly hardy everywhere. All our stock is grafted from the original Koster specimen and its descendants, and therefore all alike in color. Seeing the splendid form and color of our trees, one customer ordered 200 of them.

P. p. g. pendula. This is the greatest acquisition in conifers in many years. All the branches, even the young shoots, are very drooping; has the same striking blue color as Koster's Blue Spruce.

\section{PINUS. Pine}

The Pines are essentially inhabitants of the poor sandy soils and dry situations. Their stout root system enables them to seek the scanty water supplies where other species find it diffi- 


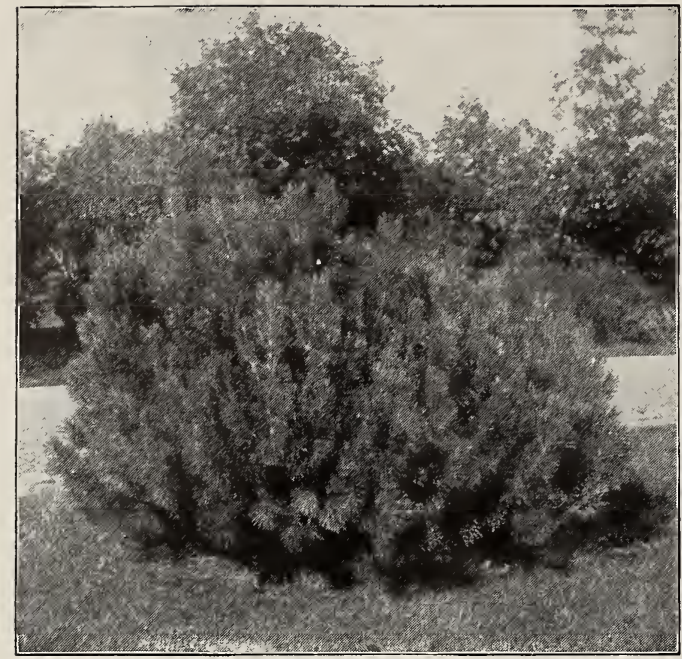

PINUS MUGHO

cult. Some, like the White Pine, are adapted to a variety of soil conditions, but only a few can endure a surplus of water.

Pinus excelsa. Himalayan or Bhotan Pine. Majestic rapid-growing tree; should be planted in poor soil lest it grow too rapidly. In its native habitat it reaches a height of 150 feet. Taken all in all, it is a great favorite, "having a charmingly graceful habit and soft, pretty, glaucous foliage."

P. Strobus. White, or Weymouth Pine. It is beautiful in every situation of its growth, from a plant to a stately tree of 150 feet. When well established, this tree will grow from $2^{1 / 2}$ to 3 feet every year. There is no prettier native Pine than this, and it is easily grown on all soils; in fact, were we to consider its economic importance, its adaptability to climate and soil or its ornamental use, we must give it chief place among our native Pines.

P. Austriaca. Austrian or Black Pine. A massive and handsome tree of spreading habit. Foliage deep blackish green. One of the best Pines for forming screens and shelter for more tender trees. Is perfectly hardy and thrives in any moderately dry soil. Flourishes near the seacoast and on high bleak hills.

P. Cembra. Swiss Stone Pine. This is dwarf, of conical growth ; very compact and symmetrical. We consider this one of the choicest dwarf evergreens in the list. We offer a fine stock.

P. Mugho. Dwarf Mountain Pine. A bushy species, indigenous to northern Europe. Forms a dense bush and keeps below 4 feet in height for many years. This is one of the scarcest varieties in the market. Our stock is unusually fine.

\section{RETINISPORA}

Retinisporas are dwarf and compact, handsome, formal-growing evergreens, particularly useful for the planting of evergreen beds and as specimens in front of larger-growing evergreens. They thrive best in moist soils and situations not too much exposed to wintry gales. No group of evergreens is more used than this for ornamental gardening.

Retinispora filifera. Very graceful, with its long, drooping tips ending in slender tassels. The color is most beautiful green and the shape pyramidal.

R. f. aurea. This is a dwarf golden variety of the preceding; it is the most graceful of all the Retinisporas; scarce and expensive.
Retinispora obtusa. This is the strongest grower of the Retinispora family and forms a handsome specimen ; foliage fern-like and of a clear green color.

R. o. aurea. Identical with Obtusa except in color, which is a deep golden yellow; one of the most striking in colored evergreens.

R. o. compacta. A very strong-growing, dwarf form; color very similar to that of Obtusa.

R. o. nana aurea. Deep green, glossy foliage, tipped yellow; a gem among evergreens. Choice plants.

R. plumosa. Light green; soft feathery plume-like foliage; very graceful habit.

R. p. aurea. One of the most beautiful golden evergreens at all seasons.

R. pisifera. Fine feathery foliage, with delicate branches.

R. p. aurea. A beautiful golden form, with same delicate foliage as Pisifera. Growth tesselated and very wavy; vigorous habit. One of the best.

R. squarrosa Veitchii. A handsome glaucous tree, striking in appearance and color.

\section{SCIADOPITYS}

Sciadopitys verticillata. Umbrella Pine. Like many others of our choice plants, this beauty comes from Japan. It is unique among evergreens. The peculiar growth of the leaves in parasol-like whorls gives the variety its name. This tree is hardy as far north as Portland, Me. (according to Professor Bailey). Its compact, conical form, glossy dark green foliage and adaptation to all soils, render it a very desirable tree. No collection should be wanting in this species. WV offer a fine stock.

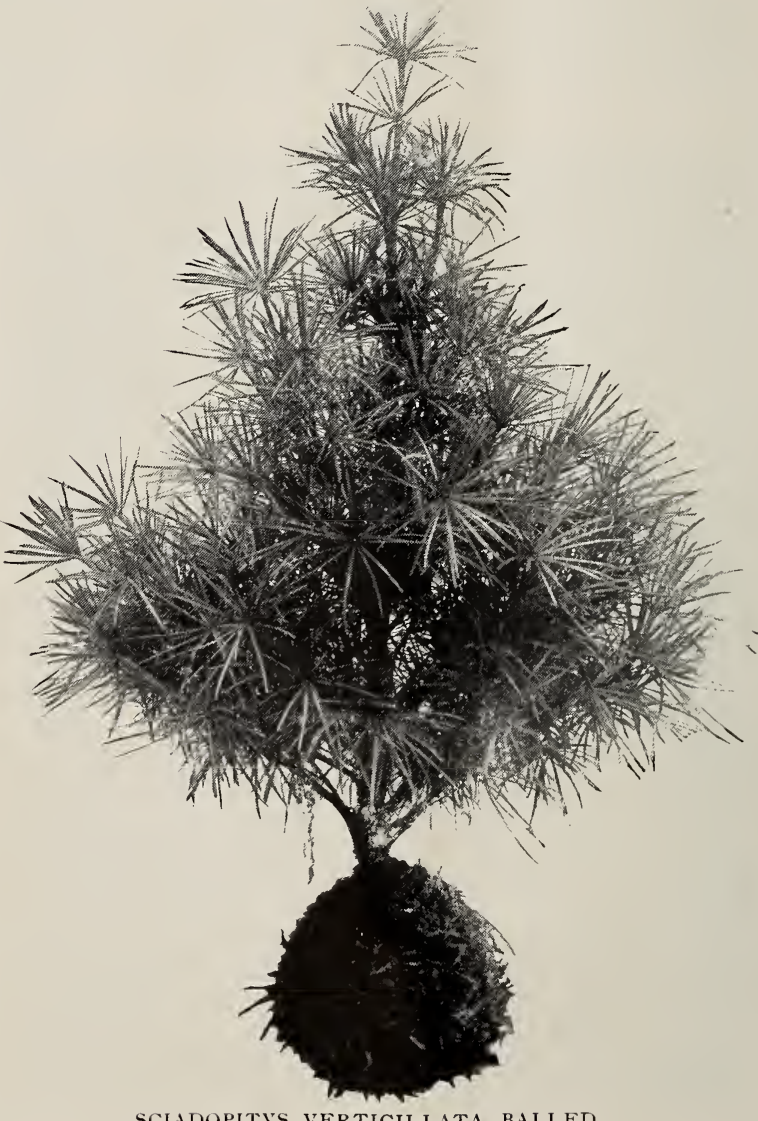

SCIADOPITYS VERTICILLATA, BALLED 


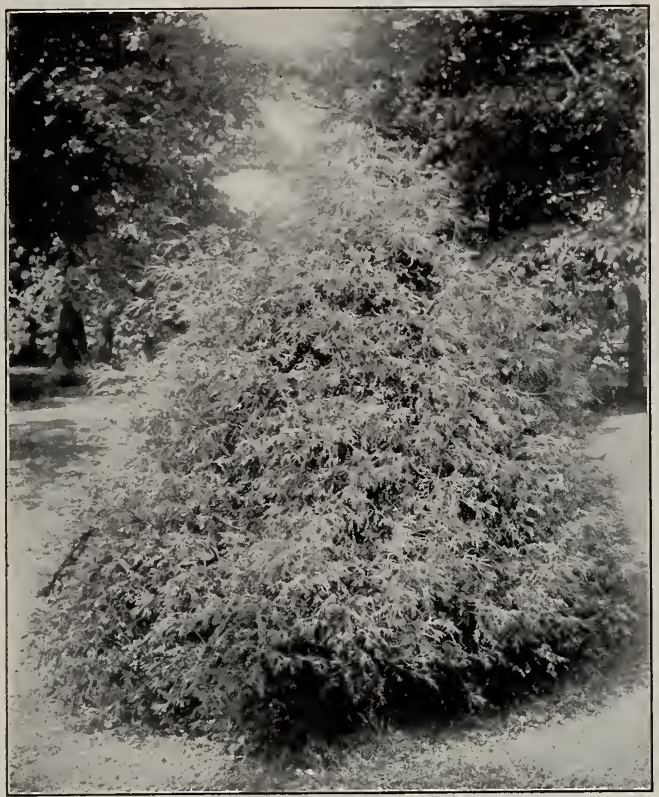

RETINISPORA FILIFERA (See page 38)

\section{TAXUS. Yew}

The Yews are very desirable evergreens for park planting. They are densely clothed with dark green foliage, well suited for hedges and easily trimmed in in any desirable shape. They thrive best in a moderately moist, sandy loam, and endure shade well; easily transplanted if a sufficiently large ball of earth is taken with the roots.

Taxus baccata. English Yew. Hardy as far north as Rhode Island and northwestern New York.

T. b. elegantissima. Golden English Yew. One of the most valuable golden-leaved evergreens. In June and July the leaves of the new growth are a bright straw-color, rendering the plant highly effective whether planted alone or with other evergreens; one of the very hardiest of the Yews.

T. cuspidata. Japanese. Beautiful spreading habit, foliage light green.

T. Hibernica. Irish Yew. A most beautiful fastigiated form of dark evergreen. The hardiest of the Yews.

T. H. aurea variegata. Very beautifully striped and margined yellow. Choice specimen plants; perfect pyramidal shape.

T. Washingtoni. Washington's Golden Yew. Foliage handsomely variegated with yellow spots and stripes.

\section{THUJA. Arborvitae}

Ornamental evergreen trees of narrow, pyramidal habit. Thujas are favorites for formal gardens because of their regular, symmetrical habit. Well adapted for hedges and windbreaks. They thrive best in a somewhat moist, loamy soil; easily transplanted.

Thuja occidentalis. American Arborvitæ. Beautiful, native tree commonly known as the White Cedar. Especially useful for hedges and screens.

T. o. compacta. A very dwarf, densely branched variety, which assumes an oval form. The foliage is richly colored and very beautiful. Nuch used in planting evergreen borders or beds; also for cemetery and house decoration.

T. o. globosa. Globe-headed Arborvitæ. Dense, low bush with rich green foliage; keeps its color well through the winter.

T. o. Hoveyi. Hovey's Golden Arborvitæ. A dwarf seedling from the American. Globular outline and bright green foliage with a golden tinge.
Thuja occidentalis lutea. Peabody's Arborvitæ. Finest and hardiest of the golden Arborvitæs. Its golden hue is the brightest and most permanent. Ilakes a fine contrast with darker-colored evergreens.

T. o. pyramidalis. Pyramidal Arborvitæ. The deep green color and upright, pyramidal form of this species renders it conspicuous in contrast with other evergreens. It is very hardy and vigorous.

T. o. Sibirica. One of the most useful of the Arborvitæs. It forms a beautiful compact specimen without shearing; foliage is full and of a peculiar dark green color throughout the year.

T. o., Tom Thumb. Dwarf variety originated in Rochester. It is remarkable for its slow growth and compact, symmetrical habit. Useful for decoration of gardens or cemeteries where large trees may not be used; also for small evergreen hedges.

T. o. Vervaeneana. A distinct and handsome yellow variety of the American Arborvitæ.

\section{THUJOPSIS}

Thujopsis cupressus Nutkaensis. Nootka Sound Cypress. A tree of nearly columnar form growing to a height of 80 to 100 feet. Resembles the Lawson Spruce, but is more robust and hardy; thrives in any ordinary soil that is not too dry.

\section{TSUGA. Hemlock}

Tsuga Canadensis. One of the most beautiful native trees; being especially rapid in growth and absolutely hardy, together with the fact that it transplants easily, makes it a very useful evergreen. Its fine feathery foliage and graceful habit make it a great favorite. The best evergreen for hedge planting. It bears the shears well and may be kept at any size and shape. Thrives in more shade than most evergreens.

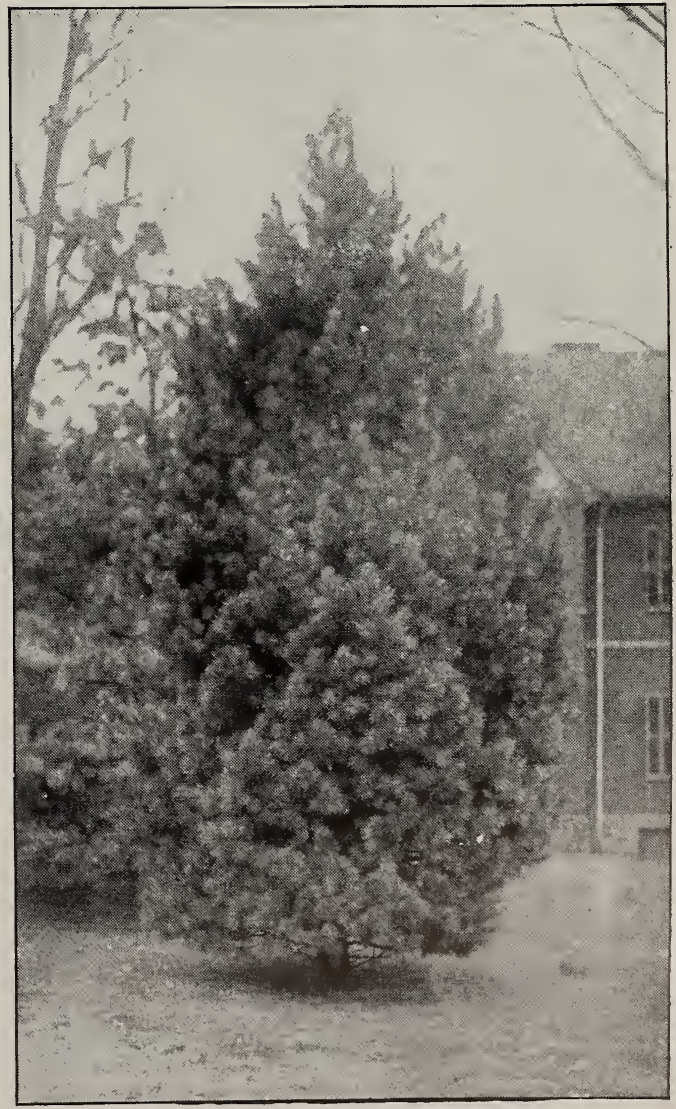

PINUS CEMBRA (See page 38 ) 


\section{Ornamental Shrubs}

\section{Group I.-Evergreen Shrubs}

This class of shrubs, as a rule, do much better in the shade, or partial shade, than in the sun. There are a few varieties, however, which do well in both sun and shade, like the Rhododendron, Kalmia, Mahonia and Ilex. They seem to stand any amount of heat and cold from twenty below zero to one hundred degrees. The foliage, however, is much finer in winter when they are planted in the shade.

Take it all in all, we consider the Mahonia one of the most valuable of all shrubs, deciduous or evergreen, since it does as well in sun as in the shade. It is perfectly hardy, a most rapid grower, with very attractive yellow flowers in the spring and succeeded by purplish berries in autumn. While it is evergreen, it has what is even better, a most superb brown, rich tone mingled with the most gorgeous scarlet and crimson, and leaves covered with a brilliant luster-like varnish. It is much improved by keeping it back by occasional clipping, as it sometimes has a tendency to straggle.

\section{RHODODENDRON. Rosebay}

Orders Booked Now for Spring Delivery

The Rhododendrons are certainly without a rival among hardy flowering shrubs, either for making a magnificent display of bloom in May and June, or for rich massive foliage at all seasons of the year.

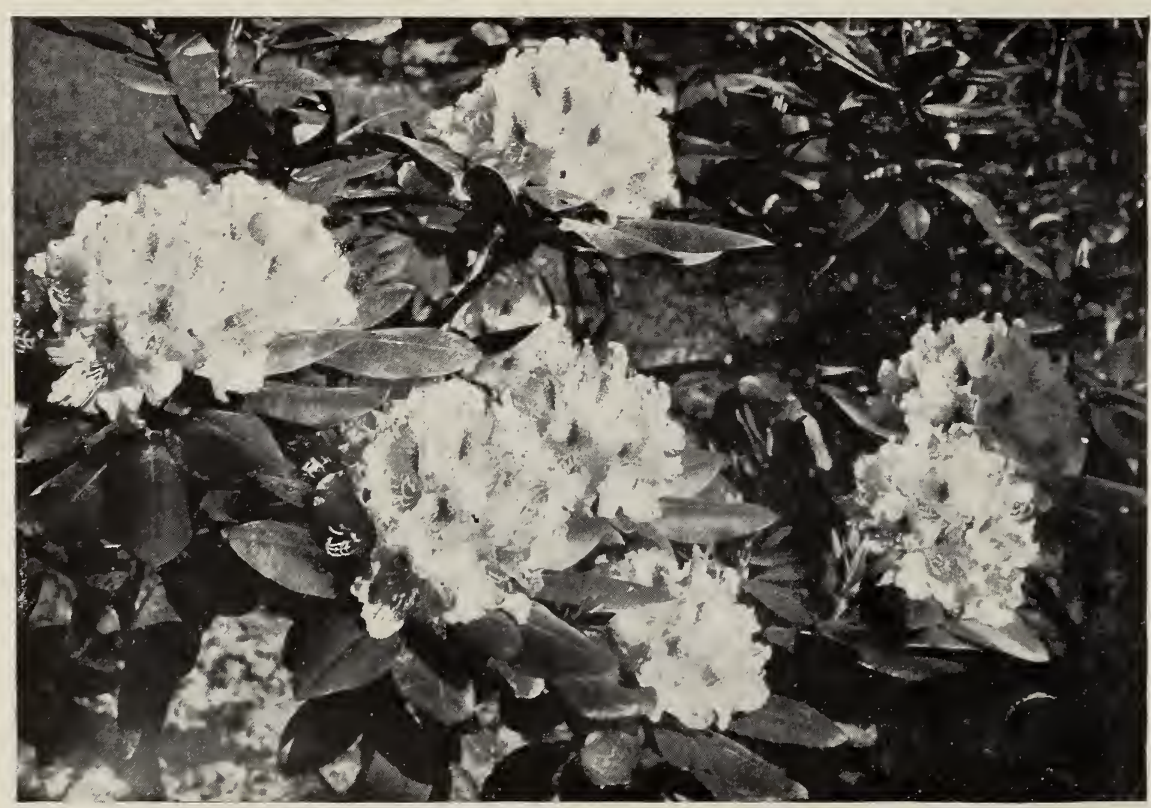

HARDY RHODODENDRON

They are steadily increasing in popularity as planters learn better how to manage them. They like a light soil in which there is plenty of peat or leaf-mold, and prefer partial shade. After the flowers havefaded the seed-pods should be re. mored, in order that the plant may use all its vigor to form bloom buds for the following season. About the middle of July the plants should be well mulched to $\mathrm{guard}$ a gainst drought, to which they are very sensitive.

Although the prices are given according to height, such classification is not entirely satisfactory, as a well-grown plant, $\mathrm{r} / 2$ feet high, is better than a poorly grown plant twice as high. Then, too, the varieties vary in height according to habit of growth. The following named varieties, thoroughly tested for hardiness, will give perfect satisfaction :

Album elegans. French white. Atrosanguineum. Deep scarlet. Caractacus. Fine purplish crimson; large truss.

Charles Bagley. Cherry-red.

Delicatissimum. Blush white.
Everestianum. Rosy lilac; large truss.

H. H. Hunnewell. Dark crimson. President Lincoln. Rose.

Kate Waterer. Rose, with yel-

low spots.

Lady Armstrong. Rosy pink.
Minnie. White, finely spotted.

Mrs. R. S. Holford. Salmon-rose.

Old Port. Plum-color.

Roseum elegans, Rose-color

Stella. Lilac, chorolate blotch.

Parson's gloriosa. Lilac.

Dear Sir:-The trees have arrived. They are fine ones, and I am well satisfied. The Rhododendrons are a fine lot, also, and I could use another hundred. Please let me know when I may expect them.

Very truly yours, 


\section{RHODODENDRON MAXIMUM. Great Laurel}

This is the native Rhododendron which blooms in midsummer and makes the wooded hillsides and mountains of the eastern and middle states so magnificent with their white, blush and delicate pink flowers. They are used in great numbers on large estates, being much cheaper than the grafted varieties and more suitable in certain locations, although the bloom is not so attractive as that of the latter.

A mass of these superb shrubs were planted in the spring of 1900 , under the trees where grass could not be made to grow, on one of the finest estates in Ossining. Every plant did well, notwithstanding the seasor? was the most trying for many years. This is about the only plant that will succeed in such dense shade where grass will not grow at all. My foreman has had large and successful experience in handling this native Rhododendron and Kalmia latifolia (Mountain Laurel) and knows just how to select and lift with large balls of earth, so that plants are sure to grow.

Plants carefully selected, well set with buds, bushy nearly to the ground, and lifted with large balls of earth, give universal satisfaction. The fact that I sell thousands of these plants every year and ship to the same buyers two and three years in succession proves not only the quality but the price to be correct.

Sizes run from I to 6 feet in height, with diameter nearly equal to height, Sizes will be graded or any particular sizes selected as desired. Superb plants. Special prices on car and halfcar lots. A mass of these native Laurels, bordered with the choice grafted sorts we import from England, makes the greatest addition pos sible to the shrubbery planting.

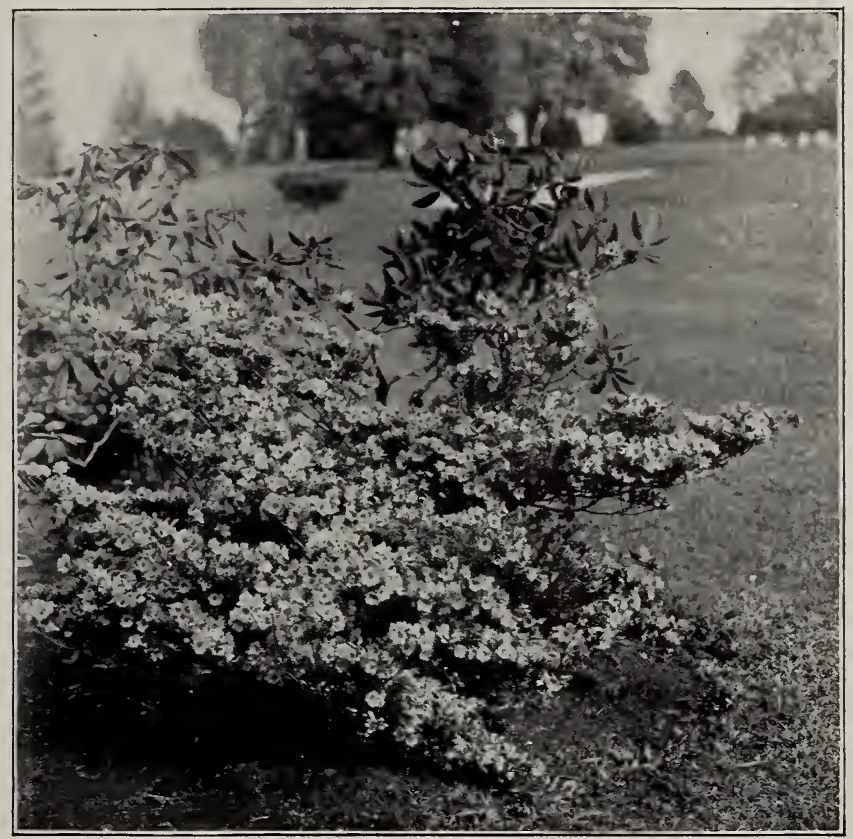

AZALEA AMCENA

\section{AZALEA}

Azalea amoena. The most showy of very dwarf evergreen shrubs. : The bushes fairly cover themselves with bright rose-colored flowers; in winter foliage turns bronzy purple. Very useful for bordering other Azaleas and Rhododendrons. Plants, all hushy and well budded.

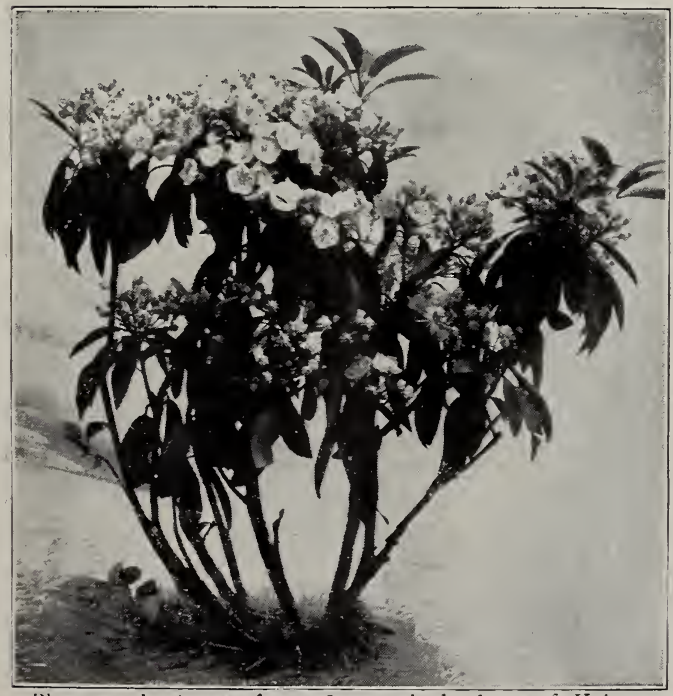

Photograph ot one of our I8- to 24 -inch plants
KALMIA. Mountain Laurel

Kalmia latifolia. Next to the rhododendron in beauty, this native shrub is being planted extensively in the finest landscape work. For cut-flowers it is most satisfactory. Cut in the bud they will last in bloom in vases of water for two weeks. It blooms later than the named varieties of rhododendrons, and earlier than Rhododendron maximum. Requires same treatment as rhododendrons. Car and half-car lots priced on application. We also offer fine nursery-grown stock, well budded.

\section{BUXUS. Box}

Buxus sempervirens. The Tree Box is a beautiful shrub well adapted for small places, and may be used to good advantage with small evergreens in larger plantings, and it is now in great demand for formal gardens. Superb plants. See page 35 .

B. S. nana. Dwarf Box Edging. This little gem is again in great demand for edging walks in oldfashioned flower-gardens.

\section{MAHONIA}

Mahonia Aquifolium. Holly-leaved Mahonia. Beautiful at all seasons of the year; in winter the prickly. shiny, purplish leaves turn to the finest bronze and crimson. In spring the whole picture changes-the polished leaves are green again and the bushes are fuller of bee music than any other plant then in bloom. Grows + to 5 feet in height. Strong, stocky plants.

Seeing the superiority of our stock, one customer ordered nearly $\$ 4,000$ worth 


\section{Group II.-Hardy Climbing Shrubs}

\section{ACTINIDIA}

Actinidia polygama. Silver Sweet Vine. A new and beautiful climber from Japan. The flowers are creamy white, appearing in profusion in June, and resemble the lily-of-the-valley in fragrance. The growth is vigorous; does well in shade.

\section{AKEBIA}

Akebia quinata. Japanese vine, with fine foliage, purple flowers and ornamental fruit.

\section{AMPELOPSIS}

Ampelopsis quinquefolia. Virginia Creeper. Very fine quick effect on rocks and trees.

A. Veitchii. Japan Creeper. Boston Ivy. No plant is more extensively used than this for covering walls, rocks, stumps, etc., to which it clings without any support. The handsome foliage takes on a gorgeous crimson in autumn. Extra heavy plants.

\section{ARISTOLOCHIA}

Aristolochia Sipho. Dutchman's Pipe. A native species of rapid growth, with large leaves and pipeshaped flowers; excellent for shade.

\section{CELASTRUS}

Celastrus scandens. Climbing Bittersweet, or Waxwork. A native twining plant of rapid growth, especially suitable to twine about some tall support, where its yellow flowers and clusters of orange-capsuled fruit show off to the best advantage. Will grow ro or

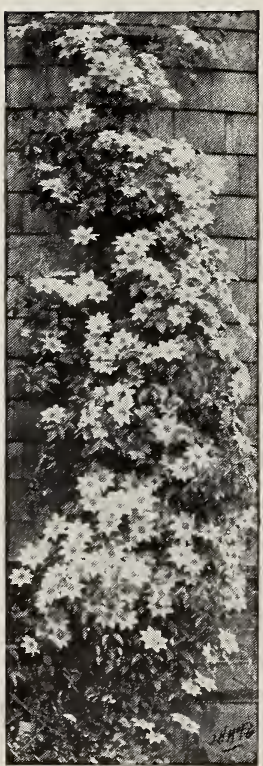

CLEMATIS feet in a season.

\section{CLEMATIS}

\section{Virgin's Bower}

The Clematis is the most showy of all climbers. It may be used in any place where a climber would be suitable except the dense shade. Plant in a sunny spot in good garden soil, dug very deep, placing the crown of the roots $3 / 4$-inch below the surface of the soil. We recommend the application of well-rotted manure in holes a few inches away from the plant in opposite directions. The feeding roots reach out to these holes, which may be watered freely, with better success than when the manure is applied directly to the base of the plant It likes plenty of moisture at the roots when in bloom.

\section{SMALL-FLOWERED}

Clematis coccinea. Flowers scarlet, bell-shaped, small.

C. Flammula. Eu ropea

Sweet. Flowers small, white and fragrant.

C. paniculata. This is the best of the small-flowered Clematis. It will grow 2o feet in a single season. Flowers are small, fragrant and very abundant.

\section{LARGE-FLOWERED}

Clematis Henryi. Very large, white; good grower, free bloomer.

C. Jackmani. This is the most vigorous and freeblooming of the large-flowered varieties; royal purple.

C., Mme. Koster. A bright rosy carmine, not so ricl in color as Mme. Andre, but a stronger, freer grower. Blooms freely in the nursery, having hundreds of flowers at two years old.
Clematis, Mme. Edouard Andre. Beautiful velvety red; free bloomer.

C., Duchess of Edinburgh. The best of the double white varieties.

C., Sieboldii. Large bright blue flowers.

C., General Grant. Lavender.

\section{EUONYMUS}

Euony mus radicans. An evergreen vine; clings to walls after the manner of ivy. Excellent for stont foundations.

E. r. variegata. Similar to the above, but with leaves margined with white.

\section{HEDERA}

Hedera Hibernica. Irish or English Ivy. Succeeds best on north sides of buildings, since it suffers from exposure to the sun in winter

\section{LONICERA. Honeysuckle}

Lonicera brachypoda aureo reticulata. Japan Golden Honeysuckle. Most beautiful netted foliage. Suitable for covering rocks.

L. Japonica. Chinese Twining Honeysuckle. A wellknown vine, holding its foliage nearly all winter. Blooms in July and September, and is very sweet.

L. periclymenum. Common Woodbine. A strong, rapid grower, with very showy flowers, red outside, buff within. June and July.

L. Belgica. Monthly fragrant, or Dutch Honeysuckle. Blooms all summer. Red and yellow, very fragrant flowers.

L. Halleana. Hall's Japan Honeysuckle. A strong grower, almost evergreen. Flowers open pure white. changing to yellow. Very fragrant and blooming in profusion from June to November.

\section{PERIPLOCA}

Periploca Graeca. Silk Vine. A rapid grower. Especially beautiful twining around a tree to the height of 30 or 40 feet. Owing to the somewhat unpleasant odor of its flowers, it should not be planted against a dwelling. Covered at midsummer with brownish red, velvety flowers.

\section{PUERARIA}

Pueraria Thunbergiana. Kudzu Vine. The most rapid-growing in cultivation. Foliage large, affording dense shade. Bears small racemes of rosy purple blossoms in August.

\section{TECOMA. Trumpet Flower}

Tecoma radicans. An old garden favorite. Clings like ivy to walls or other support. Its large, orange. trumpet-shaped flowers in August are unique and beautiful.

T. r. grandiflora. A Chinese variety with large flowers, but not so vigorous.

\section{WISTARIA}

The Wistaria should be planted in sunny places in any good soil and well pruned each year. Frutescens and Sinensis are equally suitable for arbors, trellises and pergolas, and may be grown also in shrub form on the lawn.

Wistaria Sinensis. Chinese Wistaria: A very strong grower after once established. It blooms very profusely early in summer and again more sparingly. later in the season. Flowers sky-blue, in pendulous clusters.

W. S. alba. Chinese White IVistaria. Habit same as the blue. Both may be trained up to a single stem or tree form on lawn.

W. multijuga. Dark blue flowers, borne in racemes often 2 feet or more in length.

W. m. alba. Magnificent racemes of white flowers. 


\section{Group III.-Deciduous Shrubs}

\section{ARALIA. Angelica Tree}

Aralia pentaphylla. A choice Japanese shrub of very rapid growth. . The pale green foliage gives fine contrast with other shrubs.

A. spinosa. Hercules' Club. Valuable for tropical effects when planted in groups. Should be planted in sheltered locations at the far North. Blooms in September, wlien few other shrubs are in bloom. Grows to Io or 12 feet high.

\section{AZALEA}

The Azaleas share in popularity with the rhododendron. They are perfectly hardy, having stood the exceptionally severe winters of 1903-'04 and I904-'O5 without the least protection. They seem to do equally well in either sun or shade. Effective as undergrowth among tall trees or as a border for large shrubbery.

\section{NEW AZALEAS}

Azalea Hinodegiri. An extremely hardy introduction from Japan, growing about $2 \frac{1}{2}$ feet high and producing great masses of small, single, but bright, fiery red flowers. It is claimed that this is even brighter than Azalea amonea.

A. Yodogama. Japanese Azalea. This is a perfect gem for outdoor planting, forming a strong, bushy shrub about 3 feet high, which in May is literally covered with lavender-pink flowers.

\section{OTHER AZALEAS}

Azalea Pontica. Ghent Azalea. No words can picture the beauty of this magnificent tribe of hybrids, in colurs from white to scarlet. Choice plants.

A. amoena. See page $4 \mathrm{I}$.

A. mollis. The flowers are larger and open earlier than those of the Ghent. Planted in bed or border they make a charming effect. Selected, well-budded plants, assorted colors, which will fairly cover themselves with bloom a month after planting.

A. mollis, Standard Form. Fine specimens trained in tree form; stems 3 to 4 feet, surmounted by large, well-shaped heads I2 to I 8 inches high, and as broad as high. We have secured a large stock of these plants from one of the best growers in Holland. Their Azaleas are equal to any. To introduce them to our customers we have been selling them at very low rates, and they have evoked much praise.

\section{CALYCANTHUS}

\section{Sweet-scented Shrub}

An old garden favorite valued for the fragrance of its chocolate-colored double flowers. It blooms in June and at intervals afterward; grows as well in shade as sun; 6 to 8 feet.

\section{CLETHRA. Sweet Pepperbush}

Clethra alnifolia. Spikes of white, sweet-scented flowers in August, when flowers are very scarce. Will grow on poor soil, and flourishes in wet, shady places.

\section{CORNUS. Dogwood}

Cornus sanguinea. European Red Osier Dogwood Very ornamental in winter, when the bark is bloodred.

C. Sibirica. Red Siberian Dogwood. Rare and beautiful in winter because of its bright red bark

C. S. foliis albo marginatis. Silver-leaved Dogwood. One of the finest silver-margined leaved shrubs; graceful in form and foliage.

C. Spaethi. Similar to the last named, except that the margin of the leaves is pale yellow instead of white.

\section{CORYLUS. Filbert}

Corylus Avellana atropurpurea. Purple-leaved Filbert. One of the best purple-leaved shrubs. Very dark; foliage large and beautiful.

C. A. aurea. Gold-leaved Filbert. Appears to fine advantage planted with the purple-leaved variety.

\section{CYDONIA. Japan Quince}

One of the most useful shrubs, whether as a bush on the open lawn, or on the border of shrubbery. Its large brilliant flowers, appearing in great profusion in early spring before the leaves, make it very attractive. The foliage is glossy and beautiful. Three varieties-Pink, White and Scarlet-crimson.

\section{DAPHNE}

Daphne Mezereum. Pink Mezereum. A small shrub that loads the air with the delightful fragrance of its pink flowers as soon as it is released from the icy bonds of winter.

D. M. alba. White flowers.

\section{BERBERIS. Barberry}

Berberis Thunbergi. Japanese Barberry. Of dwarf, graceful habit, and very thorny. This is ont of the best plants where a low, untrimmed hedge is desired. Its small leaves assume a gorgeous crimson color in autumn, and the slender branches droop beneath their load of red berries, which hang on all winter; it thrives in partial shade or full sun, in any soil. This is one of the few shrubs suitable for border of shrubbery, and is effectively used in Central Park.

B. vulgaris. European Barberry. A handsome shrub, with yellow flowers in drooping racemes in May or June, followed by orange-scarlet fruit.

B. v. purpurea. Purple-leaved Barberry. An interesting shrub with violet-purple foliage and fruit. Effective in groups and masses or planted alone.

\section{CEANOTHUS}

Ceanothus Americanus. A lowgrowing shrub; flowers July to September; valuable for shady places.

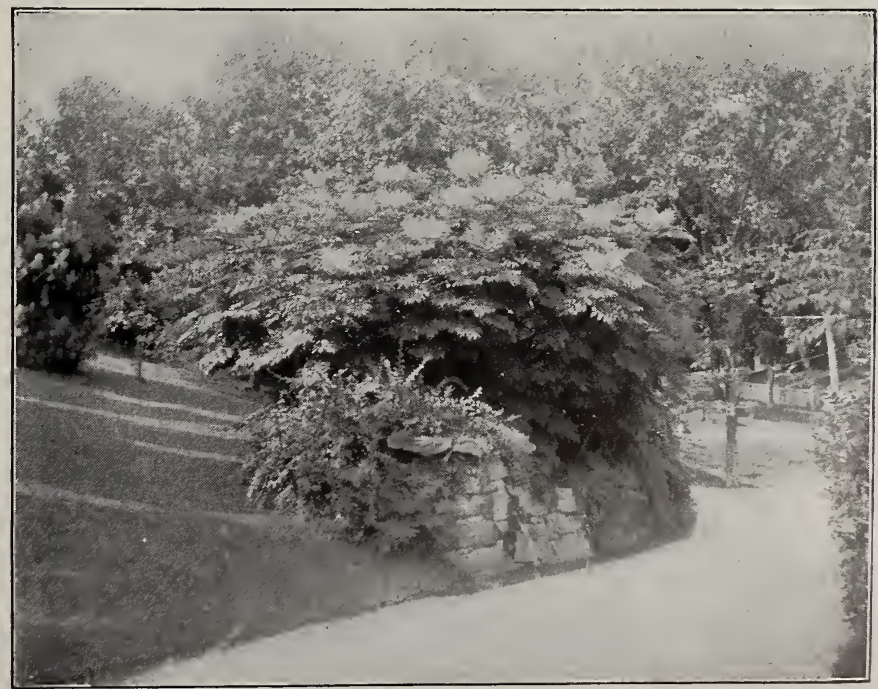

ARALIA SPINOSA 


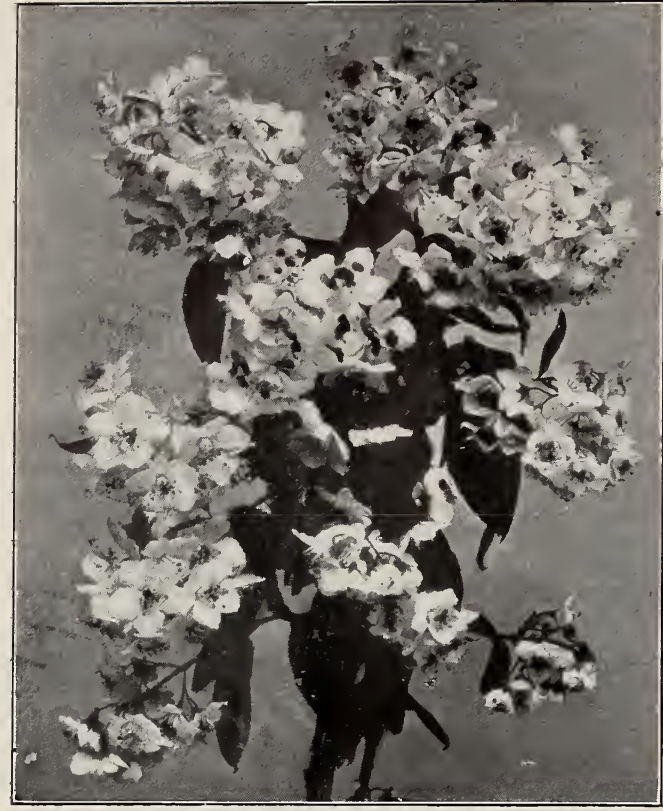

BRANCH OF DEUTZIA LEMOINEI

\section{DEUTZIA}

All the Deutzias are valuable and very profuse bloomers in June.

Deutzia crenata. Flowers double, white, tinged with rose. This is one of the best tall varieties.

D. c., Pride of Rochester. In size of flower, length of panicle and profusion of bloom, unexcelled by any of the genus.

D. gracilis. A charming shrub of dwarf habit, growing only 3 to 4 feet high, making it especially desirable in certain locations. One of the prettiest and most popular small shrubs. Very fine for forcing.

D. hybrida Lemoinei. Flowers pure white. Habit dwarf and free-flowering. Superior to D. gracilis. A great acquisition.

\section{DIERVILLA. Weigela}

Many hybrid varieties have been recently added to the beautiful species of IVeigela, some blooming in June and July, others in autumn, and varying in shade from white to dark reddish purple, which makes this one of the most useful groups for decorative purposes.

Diervilla candida. White-flowered Weigela. This variety does not bloom in June so profusely as some, but continues to bloom at intervals through the summer.

D. hortensis, A. Carriere. Bright rose; one of the best.

D. hybrida, Eva Rathke. A charming new Weigela. Flowers brilliant crimson.

D. hybrida Lavallei. Producing dark reddish purple flowers; one of the darkest varieties.

D. nana. Variegated Weigela. A neat, dwarf shrub, valuable alike for its clearly defined variegation of green, yellow and pink in its leaves and its profusion of delicate rose-pink blossoms.

D. rosea. Of erect, compact growth.

D. r. amabilis, or splendens. Dark foliage and pink flowers; blooms freely in the autumn. Distinct and beautiful.

D. r. floribunda. Flowers dark red; blooms freely.

\section{ELAEAGNUS. Oleaster}

Elaeagnus longipes. Japanese Silver Thorn. A useful new shrub. The dark brown of the new growth and the bright green leaves, with a silvery undersurface, and the abundant crop of bright-colored edible fruit make it a plant doubly valuable.

\section{EUONYMUS. Strawberry Tree}

Euonymus Europaeus. Very large shrub; espe cially attractive in autumn for the coloring of its fruit and foliage.

E. latifolia. Broad-leaved Burning Bush. Grows to a height of 15 feet, with broad; glossy leaves, which turn to purplish red in autumn. Fruit large and highly colored. Choice.

\section{EXOCHORDA. Pearl Bush}

The pure white flowers are borne on light, wiry branches which bend beneath their load of blooni. making an airy and graceful appearance, and the buds are like small, round beads of pearly whiteness.

\section{FORSYTHIA. Golden Bell}

Among the earliest-blooming shrubs; of medium size and graceful habit. Flowers yellow.

Forsythia Fortunei. Fortune's Forsythia. Growth upright, foliage dark green.

F. suspensa. Weeping Forsythia. Resembles For-

tunei, but of graceful, drooping habit.

F. viridissima. Leaves and bark deep green.

\section{HALESIA. Silver Bell Tree}

A large shrub with beautiful white, bell-shaped flowers in May. It has four-winged fruit I to 2 inches long. Very desirable.

\section{HIBISCUS. Althea, or Rose of Sharon}

The Altheas are symmetrical, rapid-growing, freeflowering shrubs. Very desirable because of their August and September bloom. They should be pruned very close in early spring.

Hibiscus Syriacus. Assorted named varieties. Standards, see page 35

H. S., var. Boule de Feu. Large, very double, wellformed flowers, of a beautiful violet-red color. Plant vigorous; flowers late.

H., var. Jeanne d'Arc. One of the best new shrubs. Flowers pure white, double; plant is a strong grower.

H., var. Leopoldii flore pleno. Large flowers; very double, flesh-color, shaded rose; leaves laciniated.

H., var. rubra pleno. Double Red Althea. Clear red; one of the best.

H., var. totus alba. Single, pure white; very fine.

H., var. variegatus flore pleno. Double Variegated, or Painted Lady Althea. White, with purple outside; petals shaded pink.

\section{HYPERICUM. St. John's-Wort}

All the Hypericums have large, yellow flowers. They possess many good qualities and no objectionable ones. They grow from $\mathrm{I}$ to 3 feet high.

Hypericum aureum. One of the finest in form and foliage.

H. calycinum. A low, trailing species; excellent for rocky places; a continuous bloomer.

H. Kalmianum. Succeeds well in shade.

H. Moserianum. Rich golden flowers resembling roses, produced in great profusion from July to October. Hardy with slight protection.

\section{HYDRANGEA}

Hydrangea paniculata grandiflora. This is the shrub most popular in all sections of the country. It blooms in great profusion from July to September. Tree or standards, see page 35 .

\section{KERRIA}

Kerria Japonica. Slender, green-branched shrub, 5 to 7 feet high, bearing a profusion of yellow flowers from July to October

K. J. fl. pl. Double-flowered Corchorus. Same habit as the preceding, with double flowers.

K. J. Argentea variegata. The Silver Variegatedleaved Corchorus. A dwarf variety from Japan; small green foliage edged with white; one of the prettiest and most useful of our dwarf shrubs, especially for edging other shrubs. 


\section{LIGUSTRUM. Privet}

The Privet is almost an evergreen, grows freely in all soil and will grow in shade where very few other shrubs will thrive. It bears shearing at will. Add to these qualities the bloom in June and July, and you have a group worthy of extensive use.

Ligustrum ovalifolium. California Privet. This is not only useful for hedges, but also for groups, because of its fine habit and foliage. See Hedges, page 35.

L. o. variegata. A form of California Privet with beautifully variegated foliage. Dwarf.

L. Ibota. Chinese, or Japanese Privet. This is one of the hardiest of all the Privets, and is now being used extensively at the North, where the California Privet has not proven hardy. Flowers large, white and very fragrant; produced in great profusion. Add to this its black berries, handsome foliage, rapid growth and the fact that it thrives in either sun or shade, and you have one of the most desirable shrubs in cultivation.

L. vulgaris. Common, or European Privet. Narrow foliage; showy white flowers; somewhat hardier than Ovalifolium. Flowers in June, followed by shining black fruit.

\section{LILAC. See Syringa}

The Lilacs have been so much improved in recent years that no less than seventy distinct varieties are offered by some growers, including early and late, double and single, and all shades. Some of the new varieties give panicles of bloom 18 inches long. By proper selection Lilacs may be had in bloom six weeks.

\section{LONICERA. Upright Honeysuckle}

The following varieties are erect shrubs valuable for their showy fruit. The climbing sorts will be found under Climbing Shrubs.

Lonicera bella albida. White flowers and showy red fruit in great profusion

L. b. candida. Another fine variety, with showy red fruit.

L. b. rosea. A choice variety with rose-colored flowers and showy fruit.

L. fragrantissima. A spreading shrub with deep green foliage, almost evergreen; fragrant flowers appear before the leaves.

L. Morrowi. A fine Japanese sort, valuable for its handsome fruit.

L. Ruprechtiana. A choice variety from Manchuria, particularly valuable for its showy fruit.

L. Tatarica. Tartarian Honeysuckle. An old and popular shrub. Beautiful pink flowers in June.

L. T. alba. White Tartarian. Creamy white fragrant flowers.

\section{PAVIA}

Pavia macrostachya. Dwarf White Horse-Chestnut. A beautiful spreading shrub growing about 6 feet high and producing numerous large, showy spikes of bloom in June. Verv fine.

\section{PHILADELPHUS Syringa, or Mock Orange}

The Syringa, an old favorite on account of its fragrant, beautiful white flowers, produced in great profusion, has not always been judiciously used. Most of the varieties form large-sized shrubs, Io to 15 feet high, and should not be planted near the house except for screen. If severely pruned. as these and many other large growers often are, they become anything but beautiful. There are some divarf varieties, but they do not flower freely. All flower in June, closely following the Weigela. We name a few of the best:

Philadelphus coronarius. Garland $\mathrm{Sy}$ ringa. Early.

P. c. flore pleno. Double-flowered Syringa.
Philadelphus foliis aureis. Golden-leaved Syringa. Useful for creating pleasing effects with purple-leaved shrubs, since it keeps its golden color well all summer.

P. Gordonianus. Gordon's Syringa. A vigorous and profuse bloomer, valuable on account of its late bloom and slightly fragrant flowers.

P. grandiflorus. Large-flowered Syringa. Vigorous, upright grower: slightly fragrant, large flowers in June; branches somewhat straggling.

P. Lemoinei erectus. Lemoine's Erect Syringa. A choice variety of upright growth, bearing small, fragrant white flowers which cover the plant in June. Height about 4 feet.

P. Yokohama. A very fragrant species from Japan, of upright, compact habit. A great acquisition.

\section{PRUNUS. Plum and Almond}

Prunus Pissardi. Purple-leaved Plum. This shrub vies with the purple filbert in color and has the advantage of retaining its color to the end of the season. Flowers small, white, single, covering the tree.

P. Japonica fl. rubra plena and alba plena. The well-known Double-flowering Almond.

\section{RHAMNUS}

Rhamnus cathartica. Buckthorn. A fine robust shrub, with dark green foliage, white flowers and small, dark fruit. A popular hedge plant.

\section{RHODOTYPOS}

Rhodotypos kerrioides. White Kerria. A choice and rare Japanese shrub, with deeply cut leaves and pure white flowers borne at intervals all summer, succeeded by numerous black fruit.

\section{RHUS. Sumac}

Rhus Cotinus. The well-known Purple Fringe or Smoke Tree. Its hair-like flow'ers, covering the whole surface of the plant for weeks, give it the appearance of a cloud of smoke or mist.

R. glabra laciniata. Cut-leaved Sumac. One of the most beautiful of shrubs, whether we think of the fern-like foliage or its brilliant color in autumn.

\section{RUBUS}

Rubus odoratus. Flowering Raspberry: The very large foliage, rosy purple flowers, and branches gracefully curving to the ground, render it one of the most effective shrubs for edging of larger shrubbery.

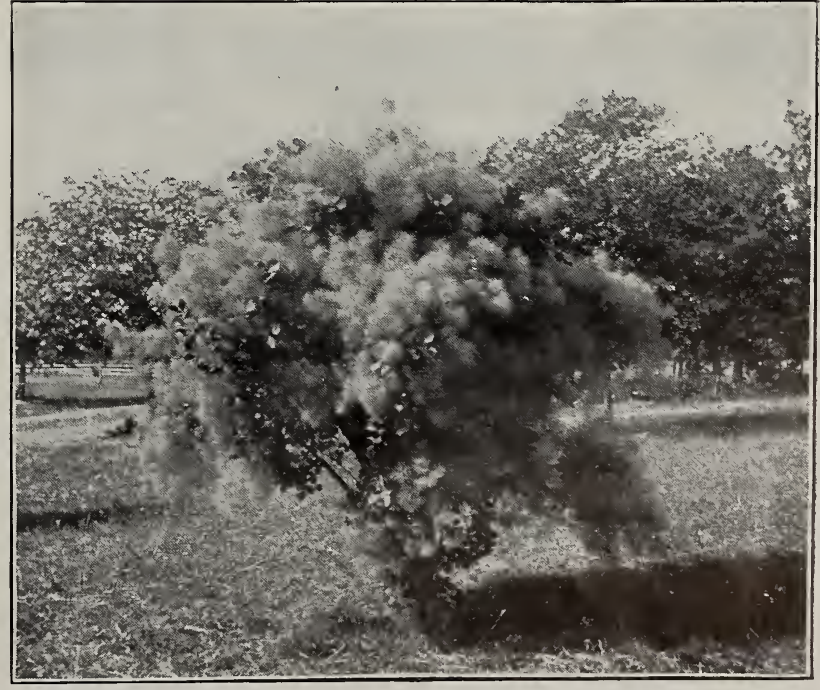

PURPLE FRINGE (RHUS CUTINUS) 


\section{SAMBUCUS}

Sambucus Canadensis. Common Elder. Broacl panicles of white flowers in June, followed by purple berries in autumn; a well-known native shrub.

S. C. acutiloba. Cut-leaved American Elder. New. A beautiful variety, with deeply and delicately cut dark green foliage. It is valuable on account of its beauty, hardiness and rapid growth, and the ease with which it is transplanted.

S. nigra. Black-berried Elder. Native of Europe; of medium size and bearing a profusion of black fruit in September.

S. n. aurea. Golden-leaved Elder. One of the most valuable large shrubs for enlivening shrubbery. The golden color is remarkably bright and constant.

S. n. laciniata. Cut-leaved Elder. A valuable variety on account of its beautiful drooping habit and deeply cut leaves.

S. racemosa foliis aureis. Cut-leaved Golden

\section{SPIRAEA. Meadow Sweet}

The Spireas are all low-growing shrubs, and among the most useful of all for profusion of bloom and graceful habit. Of many species and varieties, the following are the best.

Spiraea Anthony Waterer. Fine new d warf Spiraea, with dark, crimson flowers. Very fine: blooms constantly from June to October. Received a first-class certificate from the Royal Horticultural Society.

S. Billardi. The flowers are bright rose-color, borne in rather dense panicles; July and August.

S. Bumaldi. Very handsome species from Japan, dwarf but vigorous; bears rose-colored flowers in great profusion during midsummer and autumn.

S. callosa. Fortune's Spirea. Grows freely and blooms all summer. Rose-colored flowers.

S. c. alba. White-flowered variety.

S. opulifolia. Nine-Bark. The largest of all, and useful for screens. Grows well in shade.

S. o. aurea. Very conspicuous yellow foliage. Blooms in June, following Van Houttei.

S. prunifolia fl. pl. Double-flowered, Plum-leaved Spirea. Bridal Wreath. A beautiful variety from Japan, with pure white flowers in May; one of the earliest to bloom and keeps in flower a long time.

S. Thunbergii. All things considered, this is the most valuable Spirea. One of the first to flower, yraceful in foliage and form all summer, holding its high crimson foliage very late in autumn. Grows well in shade. Elder. A charming novelty; fern-like foliage, which retains its golden color through the season.

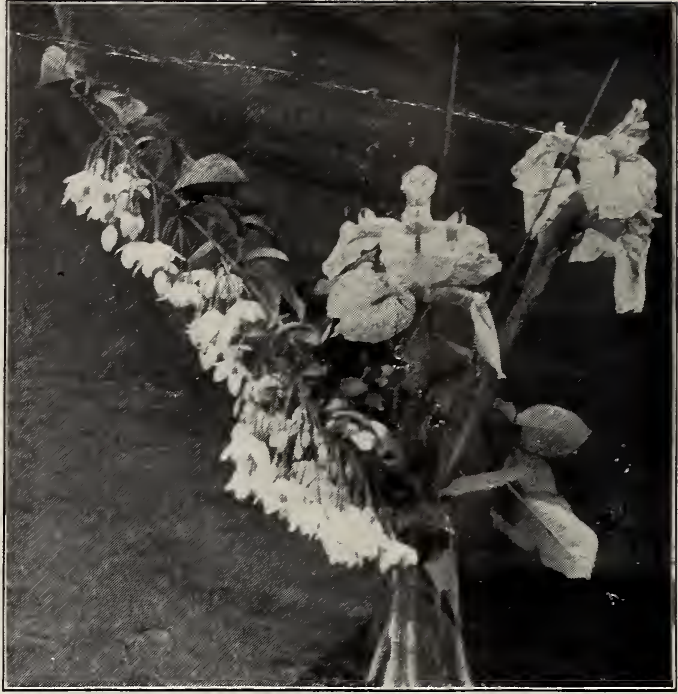

STYRAX IAPONICA AND ENGLISH IRIS

Spiraea Van Houttei. Second only to Thunbergii, which species it excels in bloom, being literally corered with large white flowers in June. Planted in the front edge of shrubbery, it gives a graceful finish to the group.

\section{STAPHYLEA. Bladder-Nut}

Staphylea colchica. One of the finest early-flowering shrubs. Flowers white, fragrant and beautiful.

S. Bumalda. A handsome shrub, with large clusters of cream-colored flowers in May.

\section{SYMPHORICARPOS. Waxberry}

Symphoricarpos racemosus. Snowberry. Dwarf shrub. Valuable for the large white berries that remain on the plant into winter. Always found in old gardens.

S. vulgaris. Indian Currant. Like the Snowberry, this little favorite will grow in shade, and is attractive in winter with its gracefully curving branches laden with masses of purple fruit.

\section{STEPHANANDRA}

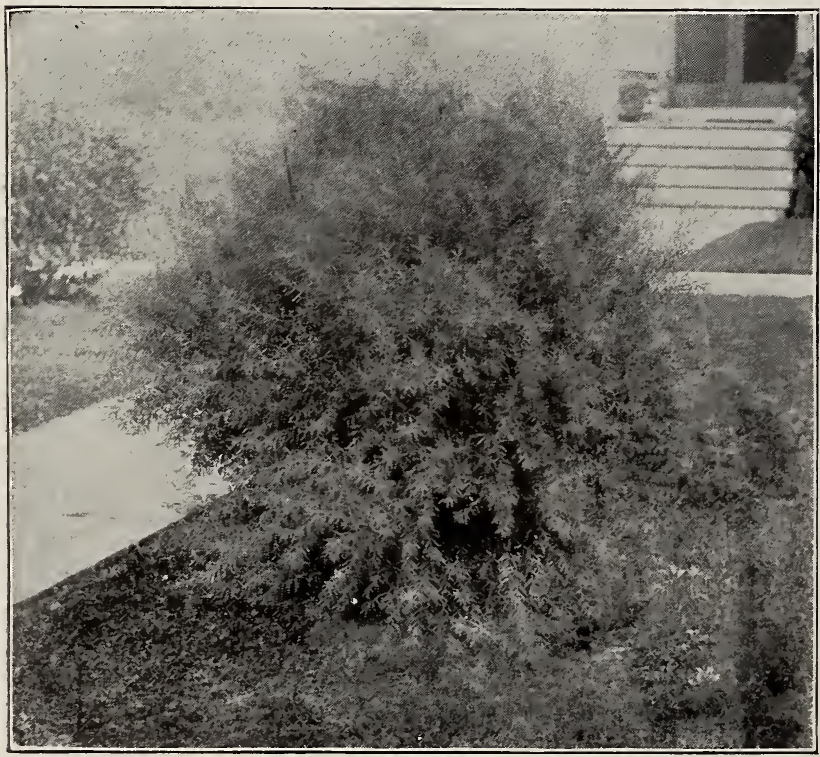

SPIREA THUNBERGII
Stephanandra flexuosa. This beautiful shrub, a native of Japan and Korea, grows to a height of 5 or 6 feet, with angular spreading branches; well adapted for borders or banks on account of its graceful foliage; white flowers in panicled racemes in June.

\section{STYRAX}

Styrax Japonica. Storax. Handsome shrub of graceful habit; numerous white flowers, very fragrant. They are well adapted for borders or as single specimens on the lawn; pendent flowers appear in great profusion in June. The picture from which the accompanying cut was made was taken at Newport on the grounds of Mrs. T. K. Gibbs, who prizes the Storax among her choicest specimens.

\section{TAMARIX. Tamarisk}

These beautiful shrubs, with their fine feathery foliage and delicate, small flowerspikes, are attractive and unique. Growing tall and bare at the base, they should be planted back of others. They succeed esnecially by the seaside, where few shrubs will grow

Tamarix Africana. May and June.

T. Chinensis. August and September. 


\section{SYRINGA. Lilac}

Plant deeply and few suckers will appear. If removed promptly when they do appear, they will vanish entirely in time and the plant will have formed roots of its own. Plant in autumn for best results, although some varieties do well if planted early in spring.

Syringa Japonica. A species from Japan, becoming a good-sized tree. Foliage dark green, glossy, leathery; flowers creamy white, odorless, in great panicles. A month later than other Lilacs.

S. Josikaea. Hungarian Lilac. From Transylvania. A fine distinct species, of tree-like growth, with dark, shining leaves and purple flowers in June, after the other Lilacs have done flowering. Esteemed particularly for its fine habit and foliage.

S. Persica. Persian Lilac. Native of Persia. From 4 to 6 feet high, with small foliage and bright purple flowers.

S. P. alba. White Persian Lilac. Delicate white fragrant flowers, shaded with purple. A superb variety.

S. Sibirica alba. Siberian White Lilac. A vigorous grower; foliage small and narrow: flowers white with bluish tint. Fragrant and free-flowering. One of the best Lilacs.

S. villosa. A species from Japan. Large branching panicles; flowers light purple in bud; white when open; fragrant; foliage resembles that of the White Fringe. Especially valuable, as its flowers appear two weeks after those of other Lilacs.

S. vulgaris. Common Lilac. Bluish purple flowers. A standard variety. Always good.

S. v. alba. Common White Lilac. Cream-colored flowers.

S. v., Charles $\mathbf{X}$. A strong, rapid-growing variety, with large, shining leaves; trusses large, rather loose, reddish purple.

S. v., Dr. Lindley. Large; compact panicles of pur plish lilac flowers; dark red in bud; very fine.

S. v. Jacques Calot. One of the finest Lilacs; very large panicles of delicate rosy pink flowers, the individual flowers unusually large; distinct.

S. v., Marie Legraye. Large panicles of white flowers; valuable for forcing. The finest white Lilac.

\section{NEW LILACS}

Syringa vulgaris, Alphonse Lavalle. Double. Very large panicle; beautiful blue, shaded violet. S. v., Belle de Nancy. Double. Very large, brilliant satiny rose, white toward the center; fine.

S. v., Dr. Von Regel. Single. Verv large panicle and flowers; rosy lilac; fine.

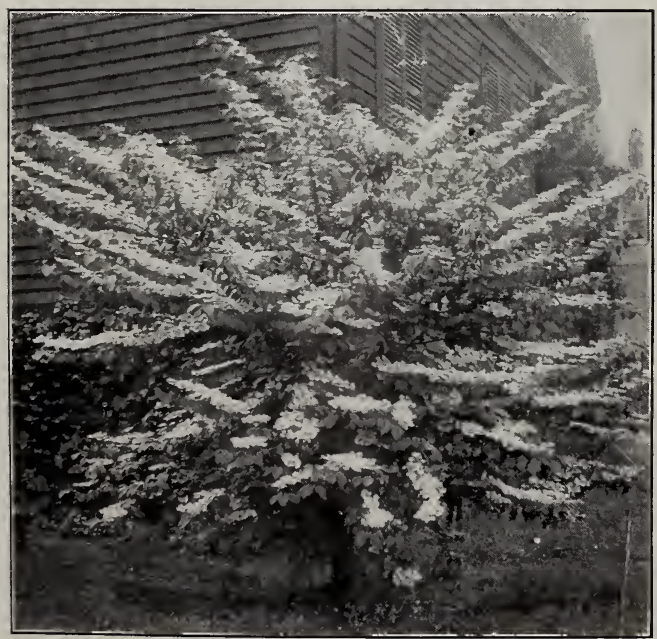

VIBURNUM TOMENTOSUM

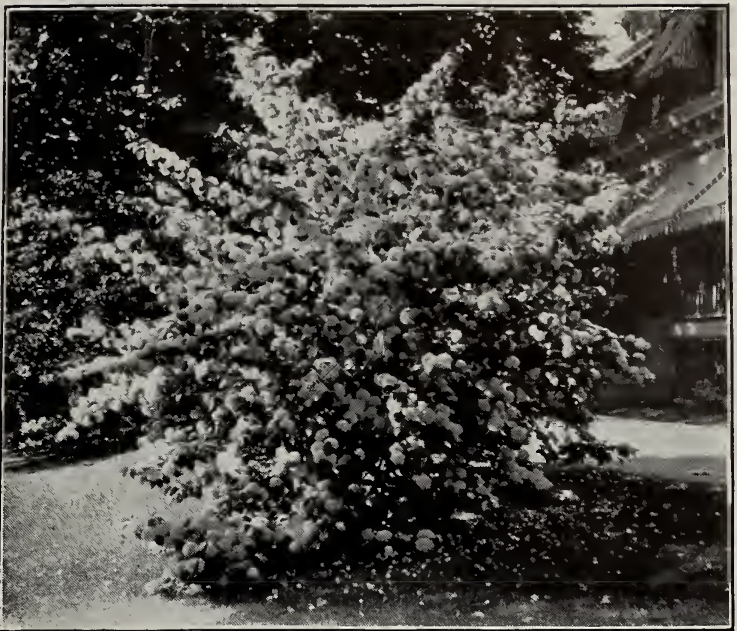

VIBLRNUM PLICATUM

Syringa vulgaris, Doyen Keteleer. Double. Very large; lavender; superb.

S. v., Emile Lemoine. Double. Flowers very large ; of fine globular form ; rosy lilac; beautiful.

S. v. Frau Dammann. Single white Lilac; panicle is very large: flowers of medium size and pure white. S. v., Fuerst Lichtenstein. Single. A magnificent Lilac after the style of Jacques Calot. Rosy lilac.

S. v., Lamarck. Very large panicle; individual flowers large, rery double, rosy lilac; superb when open.

S. v., Ludwig Spaeth. Panicle long; individual flowers large, single; dark purplish red; distinct; superb; the finest of its color.

S. v., Madame Lemoine. Double. Superb double white.

S. v., Michael Buchner. Plant dwarf ; panicle erect, very large; individual flowers medium, very double; color pale lilac; very distinct and fine.

S. v., President Grevy. A beautiful blue; individual flowers very double and very large, measuring three-quarters of an inch in diameter; the panicle is magnificent and measures II inches in length and 5 inches across. One of the finest Lilacs.

\section{VIBURNUM. Snowball}

Whether we consider the foliage, flowers or crimson color in autumn, the Snowballs yield to none in attractiveness. There are so many excellent varieties that this genus is sufficient of itself as a source of good material for the planting of the lawn. IVe select the four below as the best :

Viburnum acerifolium. Maple-leaved Viburnum. I)warf shrub; flat heads of white flowers in May; black fruit in autumn; will grow well in the shade.

V. dentatum. Very vigorous; flowers greenish white.

V. Lantana. Early, white, lantana-leaved Viburnum. Very strong grower with soft, heavy leaves, silvery underneath; large clusters of white flowers in May, succeeded by red fruit; retains foliage very late.

v. Opulus. High-Bush Cranberry. Shrub attaining I2 feet, with smooth, light gray branches; blooms in May and June, followed by red berries which remain until frost; very effective.

V. plicatum. Japan Snowball. We place this shruh in the front rank. It is attractive from early spring to late in autumn. Its large, globular heads of pure white flowers in May and June, its handsome plicate leaves, a most beautiful shade of green in summer, succeeding to crimson in the early autumn, make it a constant joy to the owner the whole season.

V. py rifolium. Pear-leaved. Flowers white, fragrant the last of all to flower.

v. tomentosum. A single form of the beautiful Japan Snowbail, $V$. plicatum. Flowers borne in great profusion in June; fruit vivid-red, changing to black. vigorous and very hardy. 


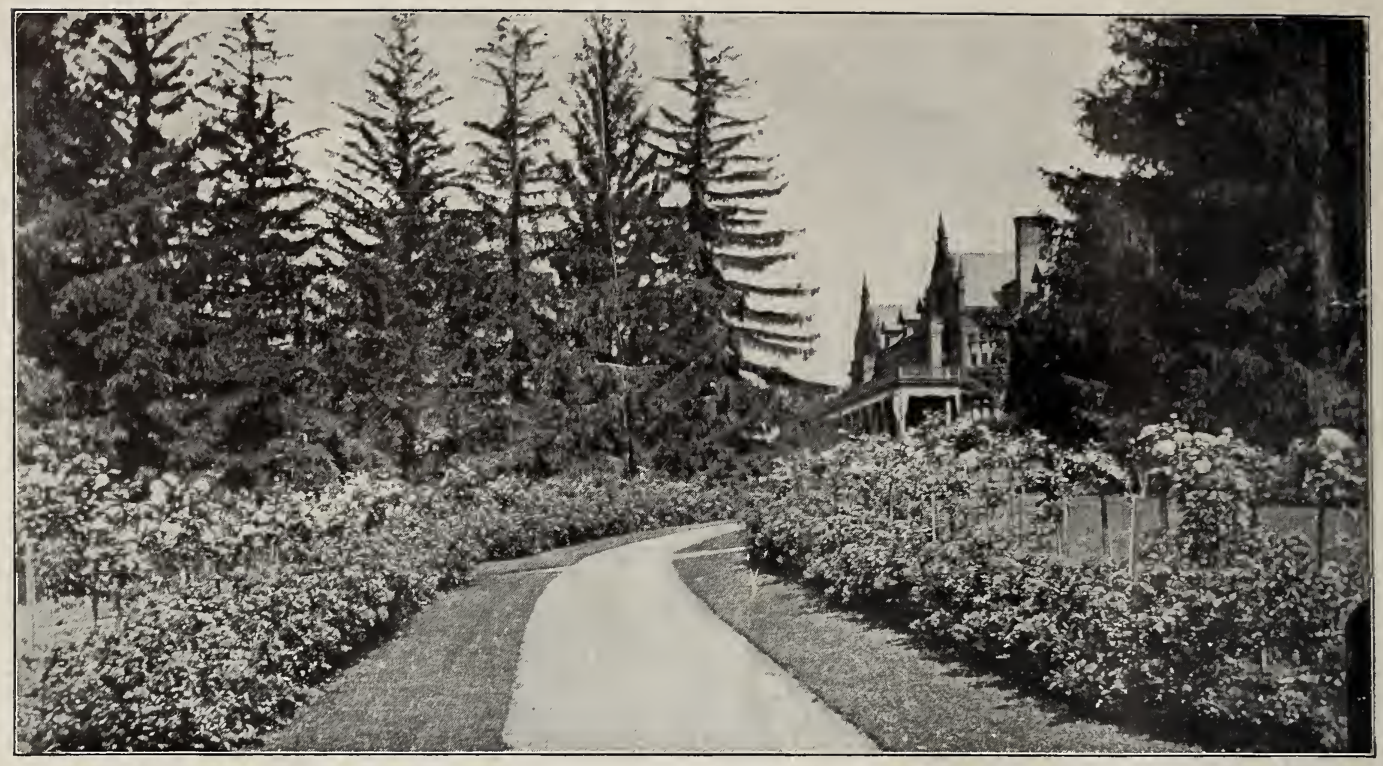

PATH TO GARDEN, SHOWING STANDARD ROSES BACK OF THUSE IN BUSH FORM

\section{LANDSCAPE DESIGN}

Having made a specialty of beautifying suburban grounds, parks and cemeteries, for a number of years, we are in a position to bring to the highest point of development, estates and gardens, either new or old. To owners in the vicinity of New York, we make no charge for a preliminary visit and advice, and our prices are moderate for plans drawn to scale. Those too far away for a personal visit we furnish a planting plan with which they will find it easy to plant for the best effect. We have a large, select clientele to whom we cail refer you by permission.

A visit to some of the places we have planted, and to our nurseries, would convince you that we could satisf: the most fastidious in both plans and plants. It is quite essential to success in landscape work to have not only good hardy material and a knowledge of its ultimate effect, but also some common sense-which is another expression for good taste.

Even a small plot of ground may afford an element which approaches the sweeping effect of nature's arrangement of flowers, trees, hills, meadows and stretches of water. There must be a judicious selection of trees, flowers and shrubs, with particular regard to form and color; and then located with these forms and colors ever in mind.

\section{GRASS SEED}

Several years ago the United States Government issued a bulletin on lawns and lawn-making (now out of print), in which was given the consensus of opinion of many well-known superintendents of parks, cemeteries and private estates. Benefiting by their experience, we have made a mixture of grass seed which we feel satisfied can be excelled by none. This we have named the Tarrytown Lawn Grass Seed. Given, however, the correct formula, it is even more essential that the grass seed composing a mixture should be pure.

An Attractive Lawn is the first principle of Landscape Gardening. I have, therefore, made a specialtyof supplying my customers with the highest quality of fancy cieaned Grass Seed, producing a fine effect on the new lawn by Jine 30. Much called grass seed is full of chaff and weed seeds, which have not been thoroughly eliminated. The fancy cleaned seed mixed according to the formulas I have found most successful are:

TARRYTOWN LAWN GRASS SEED. Will make a velvety lawn in sixty days.

SPECIAL MIXTURE OF LAWN-RESTORING SEED. A mixture of grasses peculiarly adapted to hard places, worn-out or other bad spots on the lawn.

OUR SHADY LAWN MIXTURE is made from species of grasses that thrive under trees and near buildings.

\section{LAWN DRESSING}

Next to good seed, proper fertilizer is necessary for the best lawn effect. The old notion of covering a lawn with offensive stable manure, annually supplying a new crop of weeds in the lawn, has given way in most places to the use of Fertilizers without Weeds. At the head of the list stands

PULVERIZED SHEEP MANURE. Produces a quick and permanent result both on lawn and garden. Used as a top-dressing, no fertilizer is quicker in effect. Excellent for mixing with the soil for greenhouse plantsone part of manure to six parts of soil. It also makes a safe, strong liquid manure.

CANADA UNLEACHED HARD-WOOD ASHES. Being in a very fine state, they are immediately available. Ashes have a favorable physical effect on the soil, owing to the lime they contain. Being very rich in potash, they are especially useful on sandy soils, which are usually wanting in potash. Ashes being most excellent for trees and shrubs also, I have arranged to supply them to my customers direct from Canada by the car-load or ton. Smaller quantities shipped from Tarrytown.

GROUND BONE is an excellent source of nitrogen and phosphoric acid and, therefore, makes an excellent supplement to wood ashes on heavier soil. Used without ashes, ground bone should be supplemented with muriate of potash.

FLOWER POTS in quantity at factory prices. 